\title{
HETEROGENEOUS SHALLOW-SHELF CARBONATE BUILDUPS IN THE PARADOX BASIN, UTAH AND COLORADO: TARGETS FOR INCREASED OIL PRODUCTION AND RESERVES USING HORIZONTAL DRILLING TECHNIQUES
}

(Contract No. DE-2600BC15128)

\section{DELIVERABLE 1.2.1A THIN SECTION DESCRIPTIONS: CHEROKEE AND BUG FIELDS, SAN JUAN COUNTY, UTAH}

Submitted by

Utah Geological Survey

Salt Lake City, Utah 84114

December 2003

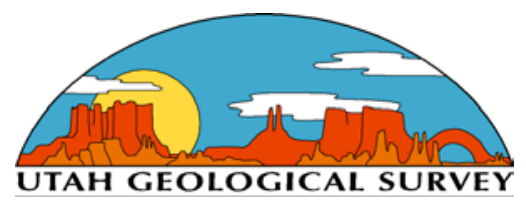

Contracting Officer's Representative

Gary D. Walker, Contract Manager

U.S. Department of Energy

National Petroleum Technology Office

1 West $3^{\text {rd }}$ Street

Tulsa, OK 74103-3532 


\section{DISCLAIMER}

This report was prepared as an account of work sponsored by an agency of the United States Government. Neither the United States Government nor any agency thereof, nor any of their employees, makes any warranty, express or implied, or assumes any legal liability or responsibility for the accuracy, completeness, or usefulness of any information, apparatus, product, or process disclosed, or represents that its use would not infringe privately owned rights. Reference herein to any specific commercial product, process, or service by trade name, trademark, manufacturer, or otherwise does not necessarily constitute or imply its endorsement, recommendation, or favoring by the United States Government or any agency thereof. The views and opinions of authors expressed herein do not necessarily state or reflect those of the United States Government or any agency thereof.

Although this product represents the work of professional scientists, the Utah Department of Natural Resources, Utah Geological Survey, makes no warranty, expressed or implied, regarding its suitability for a particular use. The Utah Department of Natural Resources, Utah Geological Survey, shall not be liable under any circumstances for any direct, indirect, special, incidental, or consequential damages with respect to claims by users of this product. 


\section{HETEROGENEOUS SHALLOW-SHELF CARBONATE BUILDUPS IN THE PARADOX BASIN, UTAH AND COLORADO: TARGETS FOR INCREASED OIL PRODUCTION AND RESERVES USING HORIZONTAL DRILLING TECHNIQUES}

(Contract No. DE-2600BC15128)

\section{DELIVERABLE 1.2.1A THIN SECTION DESCRIPTIONS: CHEROKEE AND BUG FIELDS, SAN JUAN COUNTY, UTAH}

Submitted by

Utah Geological Survey

Salt Lake City, Utah 84114

December 2003

by

Thomas C. Chidsey, Jr., Principal Investigator/Program Manager, Utah Geological Survey, and

David E. Eby, Eby Petrography \& Consulting, Inc. 


\section{CONTENTS}

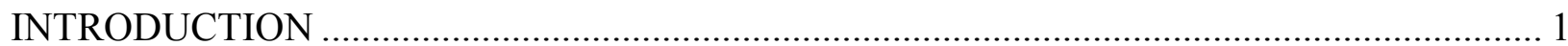

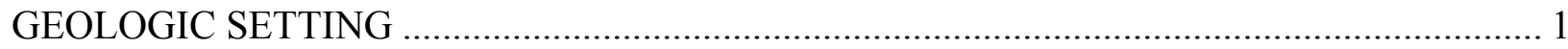

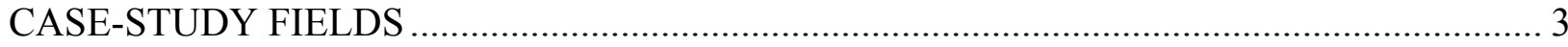

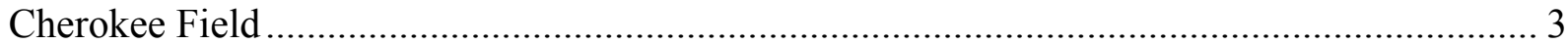

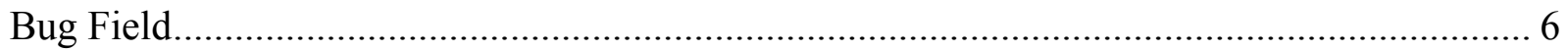

RESERVOIR DIAGENETIC ANALYSIS BASED ON THIN SECTIONS ............................. 6

Diagenetic Characterization of Cherokee Field.................................................................. 7

Diagenetic Characterization of Bug Field......................................................................... 8

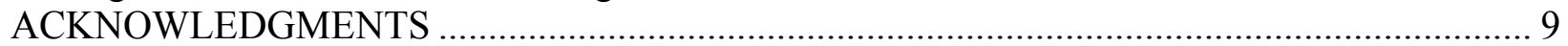

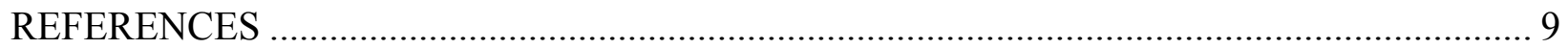

APPENDIX - THIN SECTION PHOTOMICROGRAPHS AND DESCRIPTIONS, CHEROKEE AND BUG FIELDS, SAN JUAN COUNTY, UTAH.

\section{FIGURES}

Figure 1. Location map of the Paradox Basin showing the Paradox fold and fault belt and

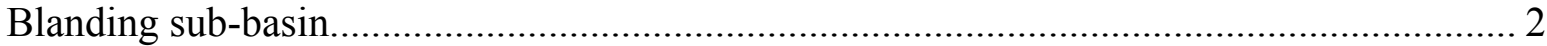

Figure 2. Pennsylvanian stratigraphy of the southern Paradox Basin ......................................... 3

Figure 3. Block diagrams displaying major depositional facies for the Ismay (A) and Desert

Creek (B) zones, Pennsylvanian Paradox Formation .......................................................... 4

Figure 4. Map showing the project study area and fields within the Ismay and Desert Creek producing trends, Utah and Colorado ................................................................................ 5

Figure 5. Photomicrograph of a peloidal packstone/grainstone dominated by microporosity, Cherokee No. 22-14 well .......................................................................................... 8

Figure 6. Photomicrograph showing dolomite dissolution including micro-box-work pores, Bug No. 10

\section{TABLE}

Table 1. List of well conventional slabbed core examined and described from project fields in the Paradox Basin of Utah. 


\section{INTRODUCTION}

Over 400 million barrels (64 million $\mathrm{m}^{3}$ ) of oil have been produced from the shallowshelf carbonate reservoirs in the Pennsylvanian (Desmoinesian) Paradox Formation in the Paradox Basin, Utah and Colorado. With the exception of the giant Greater Aneth field, the other 100 plus oil fields in the basin typically contain 2 to 10 million barrels (0.3-1.6 million $\left.\mathrm{m}^{3}\right)$ of original oil in place. Most of these fields are characterized by high initial production rates followed by a very short productive life (primary), and hence premature abandonment. Only 15 to 25 percent of the original oil in place is recoverable during primary production from conventional vertical wells.

An extensive and successful horizontal drilling program has been conducted in the giant Greater Aneth field (figure 1). However, to date, only two horizontal wells have been drilled in small Ismay and Desert Creek fields. The results from these wells were disappointing due to poor understanding of the carbonate facies and diagenetic fabrics that create reservoir heterogeneity. These small fields, and similar fields in the basin, are at high risk of premature abandonment. At least 200 million barrels $\left(31.8\right.$ million $\left.\mathrm{m}^{3}\right)$ of oil will be left behind in these small fields because current development practices leave compartments of the heterogeneous reservoirs undrained. Through proper geological evaluation of the reservoirs, production may be increased by 20 to 50 percent through the drilling of low-cost single or multilateral horizontal legs from existing vertical development wells. In addition, horizontal drilling from existing wells minimizes surface disturbances and costs for field development, particularly in the environmentally sensitive areas of southeastern Utah and southwestern Colorado.

\section{GEOLOGIC SETTING}

The Paradox Basin is located mainly in southeastern Utah and southwestern Colorado with a small portion in northeastern Arizona and the northwestern most corner of New Mexico (figure 1). The Paradox Basin is an elongate, northwest-southeast trending evaporitic basin that predominately developed during the Pennsylvanian (Desmoinesian), about 330 to 310 million years ago (Ma). During the Pennsylvanian, a pattern of basins and fault-bounded uplifts developed from Utah to Oklahoma as a result of the collision of South America, Africa, and southeastern North America (Kluth and Coney, 1981; Kluth, 1986), or from a smaller scale collision of a microcontinent with south-central North America (Harry and Mickus, 1998). One result of this tectonic event was the uplift of the Ancestral Rockies in the western United States. The Uncompahgre Highlands in eastern Utah and western Colorado initially formed as the westernmost range of the Ancestral Rockies during this ancient mountain-building period. The Uncompahgre Highlands (uplift) is bounded along the southwestern flank by a large basementinvolved, high-angle reverse fault identified from geophysical seismic surveys and exploration drilling. As the highlands rose, an accompanying depression, or foreland basin, formed to the southwest - the Paradox Basin. Rapid subsidence, particularly during the Pennsylvanian and then continuing into the Permian, accommodated large volumes of evaporitic and marine sediments that intertongue with non-marine arkosic material shed from the highland area to the northeast (Hintze, 1993). The Paradox Basin is surrounded by other uplifts and basins that formed during the Late Cretaceous-early Tertiary Laramide orogeny (figure 1). 


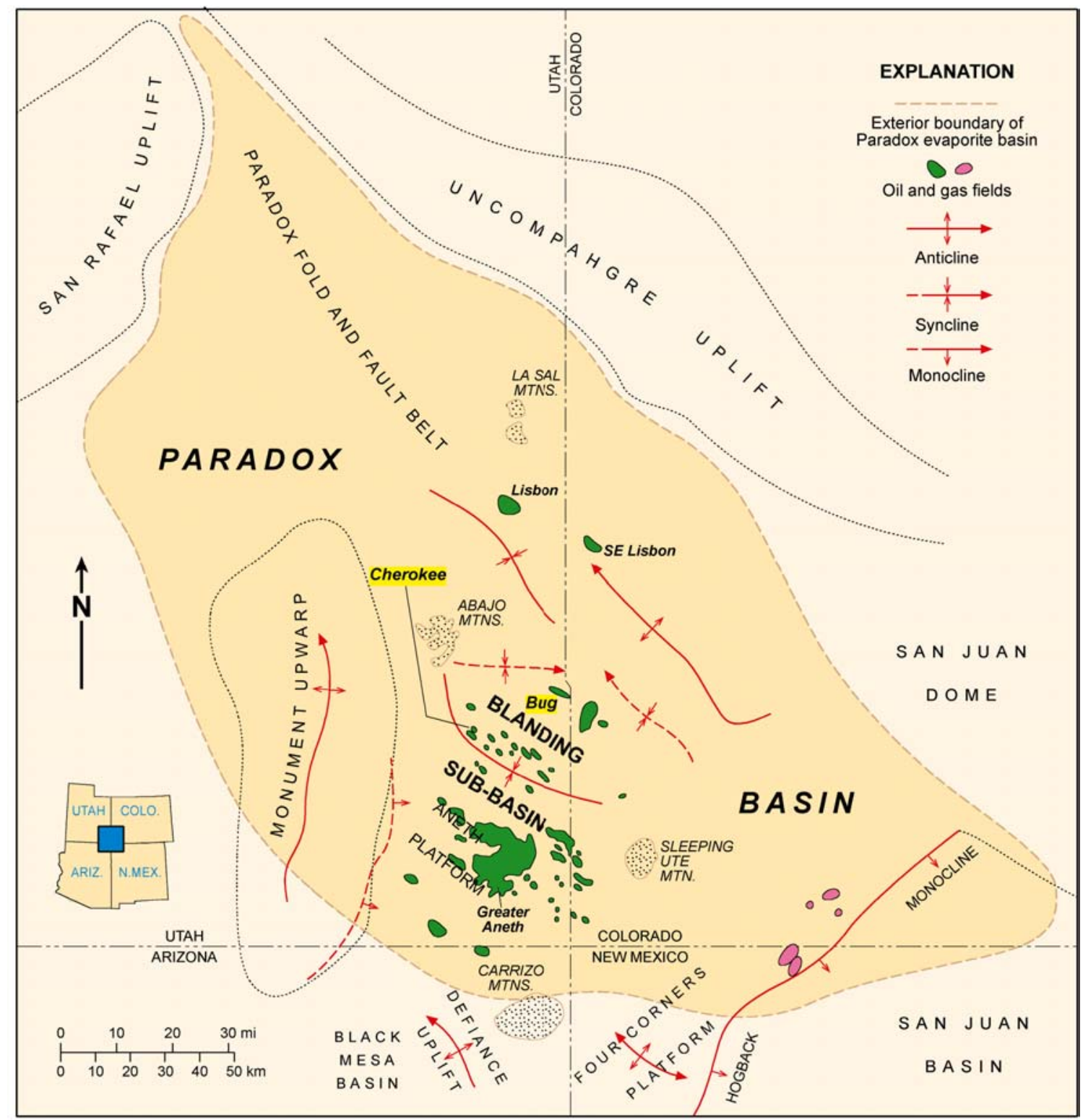

Figure 1. Location map of the Paradox Basin, Utah, Colorado, Arizona, and New Mexico showing producing oil and gas fields, the Paradox fold and fault belt, and Blanding sub-basin as well as surrounding Laramide basins and uplifts (modified from Harr, 1996).

The Paradox Basin can generally be divided into two areas: the Paradox fold and fault belt in the north, and the Blanding sub-basin in the south-southwest (figure 1). Most oil production comes from the Blanding sub-basin. The source of the oil is several black, organicrich shales within the Paradox Formation (Hite and others, 1984; Nuccio and Condon, 1996). The relatively undeformed Blanding sub-basin developed on a shallow-marine shelf which locally contained algal-mound and other carbonate buildups in a subtropical climate. 
The two main producing zones of the Paradox Formation are informally named the Ismay and the Desert Creek (figure 2). The Ismay zone is dominantly limestone comprising equant buildups of phylloid-algal material with locally variable small-scale subfacies (figure $3 \mathrm{~A}$ ) and capped by anhydrite. The Ismay produces oil from fields in the southern Blanding sub-basin (figure 4). The Desert Creek zone is dominantly dolomite comprising regional nearshore shoreline trends with highly aligned, linear facies tracts (figure 3B). The Desert Creek produces oil in fields in the central Blanding sub-basin (figure 4). Both the Ismay and Desert Creek buildups generally trend northwest-southeast. Various facies changes and extensive diagenesis have created complex reservoir heterogeneity within these two diverse zones.

\section{West}

East

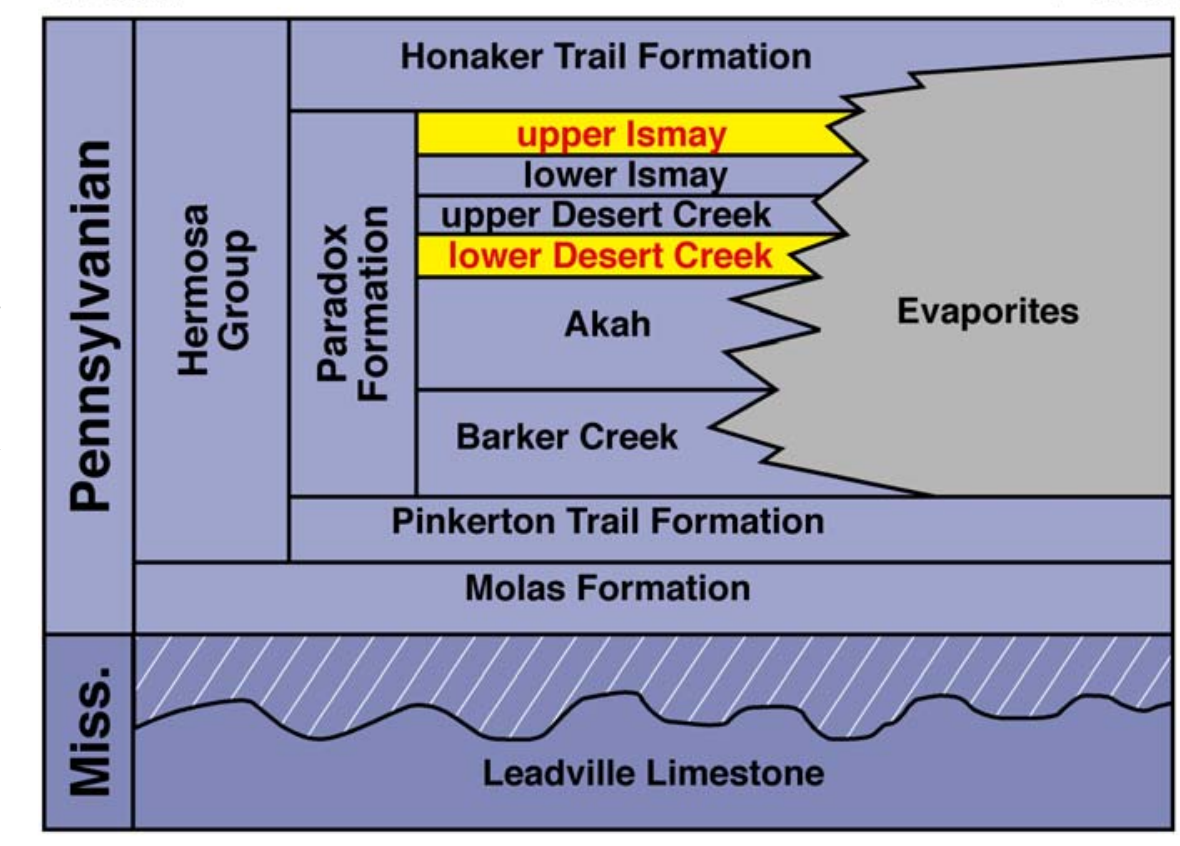

Figure 2. Pennsylvanian stratigraphy of the southern Paradox Basin including informal zones of the Paradox Formation; the Ismay and Desert Creek zones productive in the casestudy fields described in this report are highlighted.

\section{CASE-STUDY FIELDS}

Two Utah fields were selected for local-scale evaluation and geological characterization: Cherokee in the Ismay trend and Bug in the Desert Creek trend (figure 4). This evaluation included data collection and thin section analysis of these fields as presented in this report.

This geological characterization focused on reservoir heterogeneity, quality, and lateral continuity, as well as possible compartmentalization within the fields. From these evaluations, untested or under-produced compartments can be identified as targets for horizontal drilling. The models resulting from the geological and reservoir characterization of these fields can be applied to similar fields in the basin (and other basins as well) where data might be limited.

\section{Cherokee Field}

Cherokee field (figure 4) is a phylloid-algal buildup capped by anhydrite that produces from porous algal limestone and dolomite in the upper Ismay zone. The net reservoir thickness is 27 feet $(8.2 \mathrm{~m})$, which extends over a 320-acre (130 ha) area. Porosity averages 12 percent with 8 millidarcies (md) of permeability in vuggy and intercrystalline pore systems. Water saturation is 38.1 percent (Crawley-Stewart and Riley, 1993). 

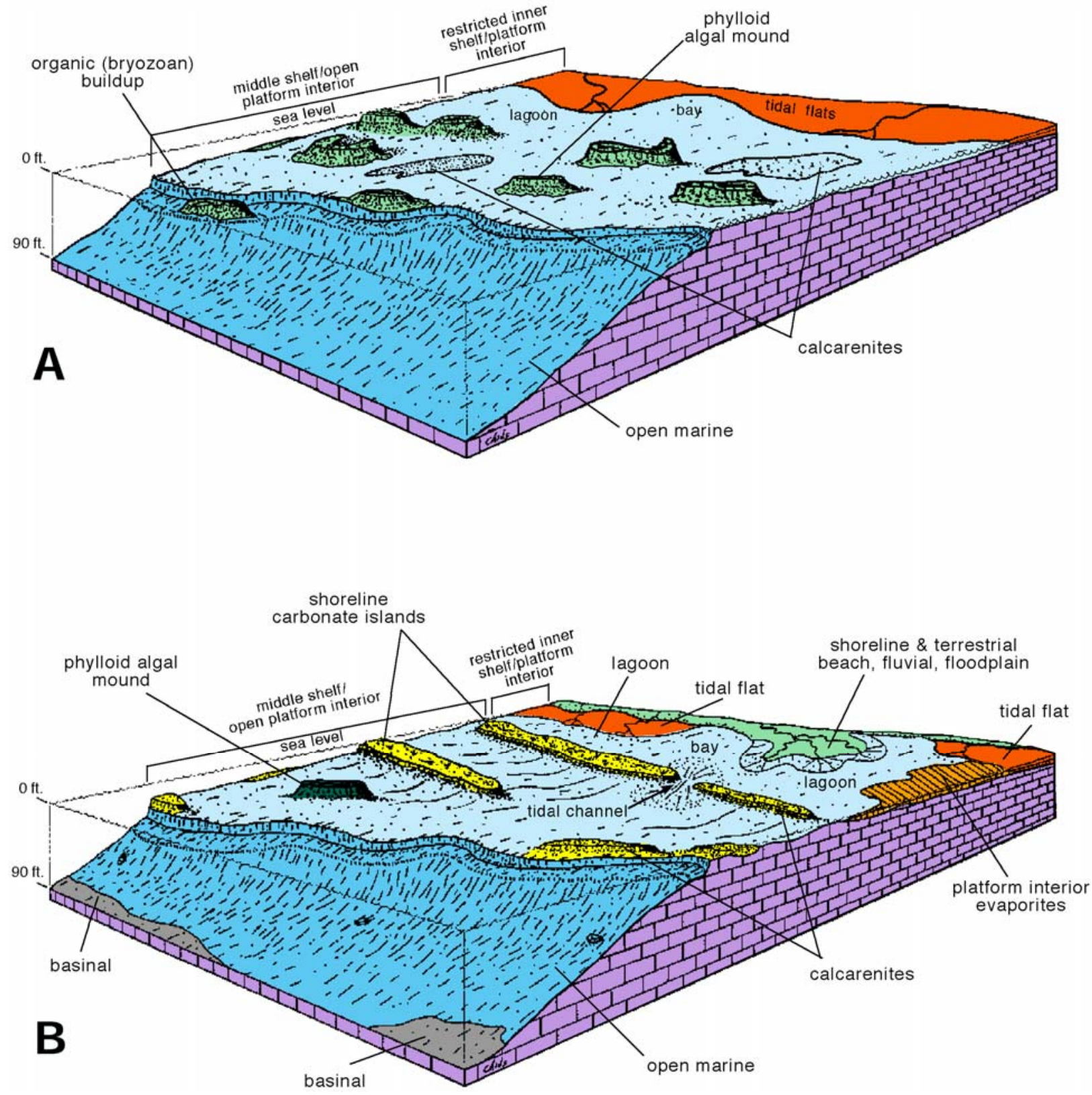

Figure 3. Block diagrams displaying major depositional facies, as determined from core, for the Ismay (A) and Desert Creek (B) zones, Pennsylvanian Paradox Formation, Utah and Colorado. 


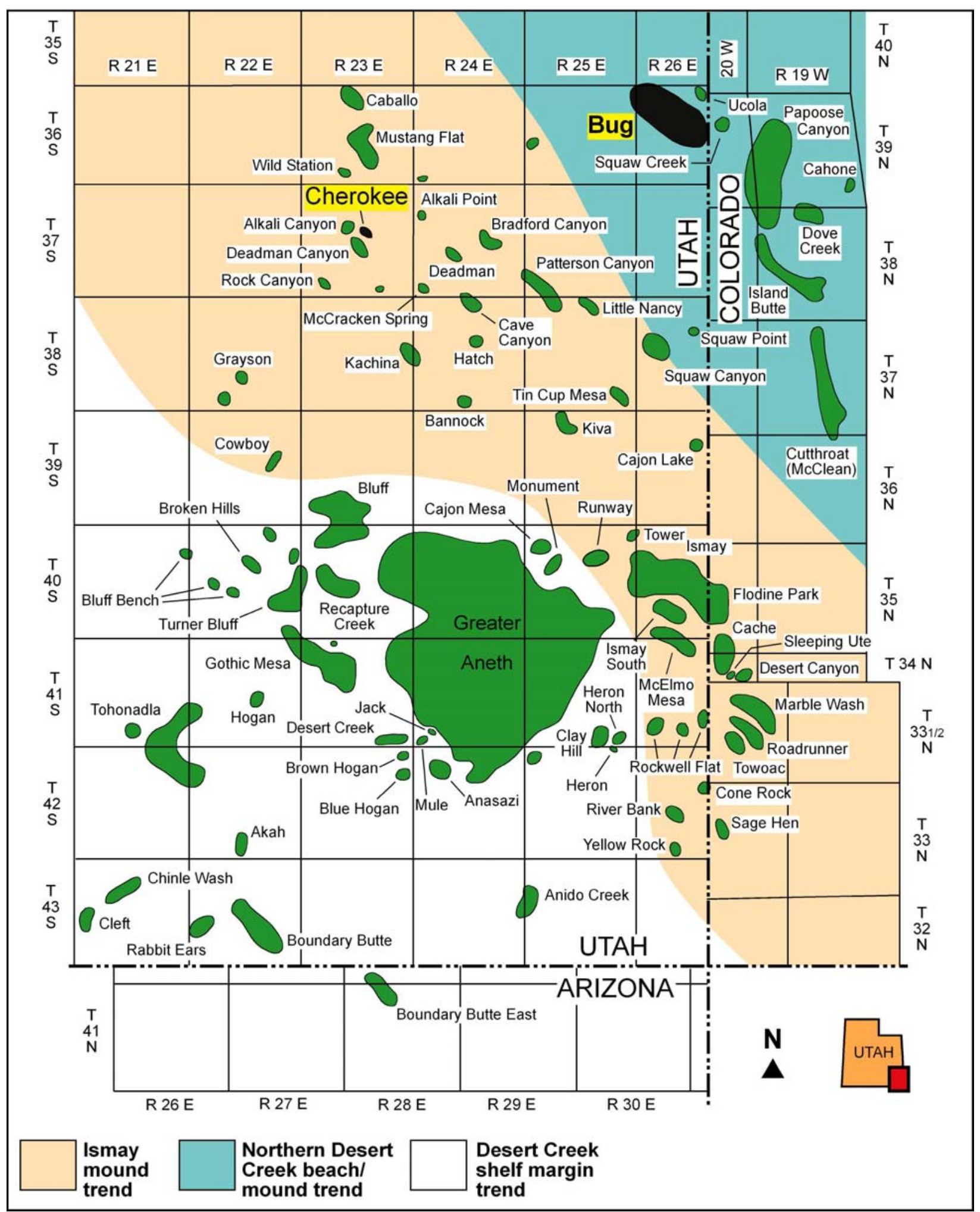

Figure 4. Map showing the project study area and fields within the Ismay and Desert Creek producing trends in the Blanding sub-basin, Utah and Colorado. 
Cherokee field was discovered in 1987 with the completion of the Meridian Oil Company Cherokee Federal 11-14, NE1/4NW1/4 section 14, T. 37 S., R. 23 E., Salt Lake Base Line and Meridian (SLBL\&M); initial potential flow (IPF) was 53 barrels of oil per day (BOPD) $\left(8.4 \mathrm{~m}^{3}\right)$, 990 thousand cubic feet of gas per day (MCFGPD) (28 MCMPD), and 26 barrels of water (4.1

$\mathrm{m}^{3}$ ). There are currently four producing (or shut-in) wells and two dry holes in the field. The well spacing is 80 acres ( $32 \mathrm{ha}$ ). The present field reservoir pressure is estimated at 150 pounds per square inch (psi) (1,034 Kpa). Cumulative production as of June 1, 2003, was 182,071 barrels of oil $\left(28,949 \mathrm{~m}^{3}\right), 3.65$ billion cubic feet of gas (BCFG) (0.1 BCMG), and 3,358 barrels of water $\left(534 \mathrm{~m}^{3}\right)$ (Utah Division of Oil, Gas and Mining, 2003). The original estimated primary recovery is 172,000 barrels of oil $\left(27,348 \mathrm{~m}^{3}\right)$ and $3.28 \mathrm{BCFG}(0.09 \mathrm{BCMG})$ (Crawley-Stewart and Riley, 1993). The fact that both these estimates have been surpassed suggests significant additional reserves could remain.

\section{Bug Field}

Bug field (figure 4) is an elongate, northwest-trending carbonate buildup in the lower Desert Creek zone. The producing units vary from porous dolomitized bafflestone to packstone and wackestone. The trapping mechanism is an updip porosity pinchout. The net reservoir thickness is 15 feet $(4.6 \mathrm{~m})$ over a 2,600-acre (1,052 ha) area. Porosity averages 11 percent in moldic, vuggy, and intercrystalline networks. Permeability averages 25 to $30 \mathrm{md}$, but ranges from less than 1 to $500 \mathrm{md}$. Water saturation is 32 percent (Martin, 1983; Oline, 1996).

Bug field was discovered in 1980 with the completion of the Wexpro Bug No. 1, NE1/SE1/4 section 12, T. 36 S., R. 25 E., SLBL\&M, for an IPF of 608 BOPD $\left(96.7 \mathrm{~m}^{3}\right), 1,128$ MCFGPD (32 MCMPD), and 180 barrels of water $\left(28.6 \mathrm{~m}^{3}\right)$. There are currently eight producing (or shut-in) wells, five abandoned producers, and two dry holes in the field. The well spacing is 160 acres (65 ha). The present reservoir field pressure is 3,550 psi $(24,477 \mathrm{Kpa})$. Cumulative production as of June 1, 2003, was 1,622,2020 barrels of oil $\left(257,901 \mathrm{~m}^{3}\right), 4.47$ BCFG (0.13 BCMG), and 3,181,448 barrels of water $\left(505,850 \mathrm{~m}^{3}\right)$ (Utah Division of Oil, Gas and Mining, 2003). Estimated primary recovery is $1,600,000 \mathrm{bbls}\left(254,400 \mathrm{~m}^{3}\right)$ of oil and 4 BCFG (0.1 BCMG) (Oline, 1996). Again, since the original reserve estimates have been surpassed and the field is still producing, significant additional reserves likely remain.

\section{RESERVOIR DIAGENETIC ANALYSIS BASED ON THIN SECTIONS}

The diagenetic fabrics and porosity types found in the various hydrocarbon-bearing rocks of Cherokee and Bug fields can be indicators of reservoir flow capacity, storage capacity, and potential for horizontal drilling. In order to determine the diagenetic histories of the various Ismay and Desert Creek reservoirs, 44 thin sections of representative samples were selected from the conventional cores of each field for petrographic description (table 1 and Appendix). Carbonate fabrics were determined according to Dunham's (1962) and Embry and Klovan's (1971) classification schemes. Each thin section was photographed with additional close-up photos of: (1) typical preserved primary and secondary pore types, (2) cements, (3) sedimentary structures, (4) fractures, and (5) pore plugging anhydrite and halite. Petrophysical data (porosity and permeability) were obtained from core plugs. 
Table 1. List of well conventional slabbed core examined and described from project fields in the Paradox Basin of Utah.

\begin{tabular}{|c|c|c|c|c|c|c|c|c|}
\hline Well & Location & API No. & $\begin{array}{c}\text { Cored } \\
\text { Interval (ft) }\end{array}$ & Field & $\begin{array}{c}\text { Stratigraphic } \\
\text { Zone }\end{array}$ & $\begin{array}{l}\text { Samples For } \\
\text { Thin Sections }\end{array}$ & $\mathbf{P} \& \mathbf{P}^{*}$ & Repository $^{\dagger}$ \\
\hline May-Bug 2 & 7-36S-26E, UT & $43-037-30543$ & $6290-6333$ & Bug & Desert Creek & 5 & yes & UGS \\
\hline Bug 3 & 7-36S-26E, UT & $43-037-30544$ & 6316-6358 & Bug & Desert Creek & 1 & no & UGS \\
\hline Bug 4 & 16-36S-26E, UT & $43-037-30542$ & 6278-6322 & Bug & Desert Creek & 4 & Yes & UGS \\
\hline Bug 7A & 7-36S-26E, UT & $43-037-30730$ & $6345-6400$ & Bug & Desert Creek & 2 & no & UGS \\
\hline Bug 10 & 22-36S-26E, UT & $43-037-30591$ & $6300-6346.5$ & Bug & Desert Creek & 3 & Yes & UGS \\
\hline Bug 13 & 17-36S-26E, UT & $43-037-30610$ & $5913-5951.3$ & Bug & Desert Creek & 4 & Yes & UGS \\
\hline Bug 16 & 17-36S-26E, UT & $43-037-30607$ & 6278-6333 & Bug & Desert Creek & 3 & Yes & UGS \\
\hline Cherokee 22-14 & 14-37S-23E, UT & $43-037-31367$ & $5768-5880$ & Cherokee & Ismay & 17 & Yes & UGS \\
\hline Cherokee 33-14 & 14-37S-23E, UT & $43-037-31316$ & 5770-5799 & Cherokee & Ismay & 5 & Yes & UGS \\
\hline
\end{tabular}

* $P \& P=$ Porosity and permeability data from core-plug analysis.

† UGS = Utah Geological Survey, Salt Lake City, Utah

Reservoir diagenetic fabrics and porosity types of these carbonate buildups were analyzed to: (1) determine the sequence of diagenetic events, (2) predict facies patterns, and (3) provide data input for reservoir modeling studies. Diagenetic characterization focused on reservoir heterogeneity, quality, and compartmentalization within the two fields. All depositional, diagenetic, and porosity information were later combined with each field's production history in order to analyze the potential for success of each horizontal drilling candidate. Of special interest was the determination of the most effective pore systems for oil drainage versus storage.

\section{Diagenetic Characterization of Cherokee Field}

The upper Ismay zone in Cherokee field consists of both limestone and dolomite, although there appears to be more dolomite in core than observed in thin section. Petrographic analysis shows the typical mound-facies limestone consists of skeletal phylloid-algal bafflestone with anhydrite plugging early pore space. The calcarenite facies consists of skeletal grainstone limestone, with primary interparticle and intraparticle porosity, and early moldic porosity. Some mixing-zone dolomite and dog-tooth spar (meteroic cement) are present. The low-energy, middle-shelf facies typically consists of dolomite, packstone/wackestone, with peloids, crinoids, and bryozoans. Early dolomitization and late solution-enlarged channels, and anhydrite and bitumen plugging are common. 
The most significant and unique diagenetic characteristic observed in the Cherokee field thin sections was extensive microporosity. In fact, much of the "dolomite" observed on the slabbed surface of the core is alteration which features microporosity. Figure 5 is a photomicrograph of peloidal packstone/grainstone dominated by microporosity. The sequence of diagenetic events consisted of: (1) early dolomitization by hypersaline or mixing zone brines, (2) stylolitization, (3) late dissolution/micropores, (4) anhydrite replacement, and (5) bitumen plugging. Our interpretation is that the intense microporosity developed late, along solution fronts by the action of aggressive hydrothermal solutions from depth (carbon dioxide escaping from Mississippian Leadville Limestone or from deep decarboxylation of organic matter). At any rate, this microporosity represents an important site for untapped hydrocarbons and possible targets for horizontal drilling.

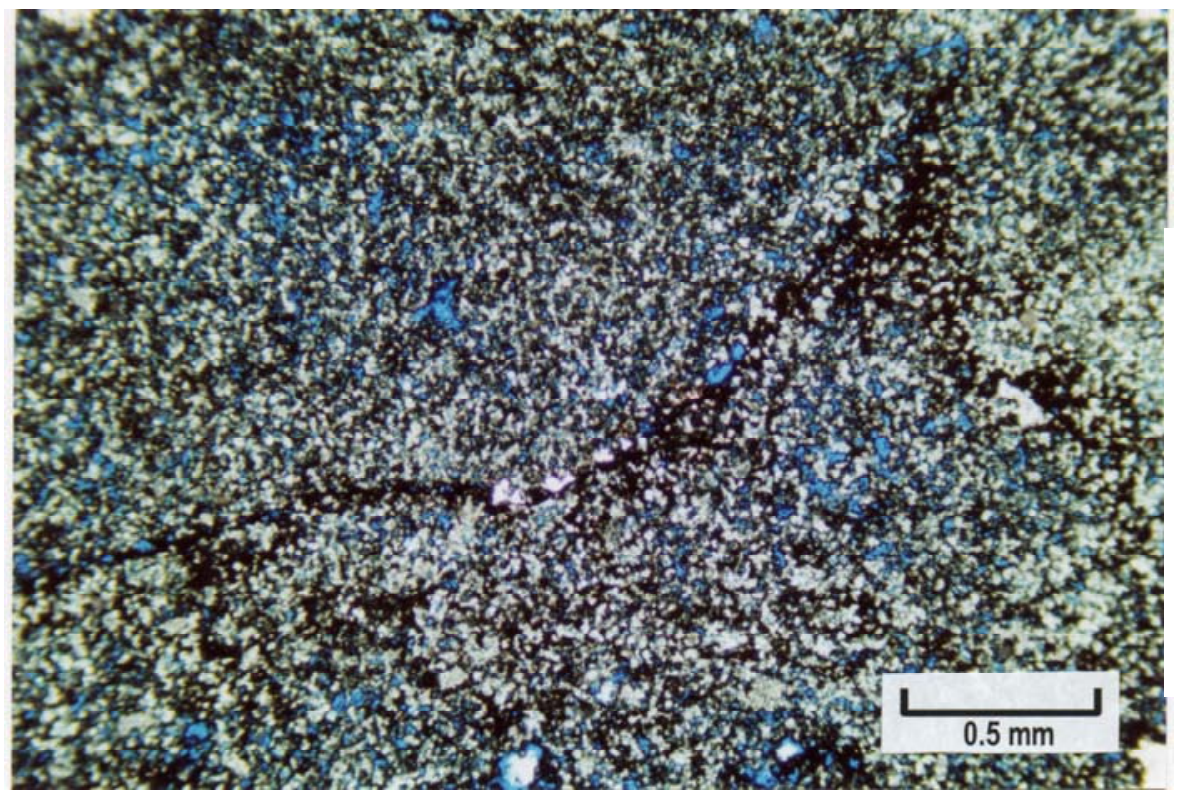

Figure 5. Photomicrograph (plane light) of a peloidal packstone/grainstone dominated by microporosity. Cherokee No. 22-14, 5,768.7 feet $(1,758.2 \mathrm{~m})$, porosity $=$ 22.9 percent, permeability $=$ 215 millidarcies.

\section{Diagenetic Characterization of Bug Field}

The lower Desert Creek zone in Bug field consists entirely of dolomite. The pore system observed in thin section shows a reservoir that has been predominantly affected by subaerial exposure. Solution-enlarged grain molds (sometimes originally phylloid-algal plates) and fractures are common; both of these types of pores are often lined with black bitumen. The remaining matrix consists of tight dolomite. Remnants of primary, interparticle pores are also observed between small pisolites and grain aggregates, but are often lined or plugged with late anhydrite cements or bitumen. The result is that both effective and ineffective pores are present.

The most significant and unique diagenetic characteristic observed in the Bug field thin sections was extensive "micro-box-work" porosity. Figure 6 is a photomicrograph showing the pattern of patchy dolomite dissolution which includes a micro-box-work pattern of pores. Some of the pores in this view occur between elongate, rectilinear networks of dolomite "lathes." Our interpretation is that the intense micro-box-work porosity developed early from subaerial exposure of the phylloid-algal buildup. Like the microporosity in Cherokee field, the micro-boxwork porosity represents an important site for untapped hydrocarbons and possible targets for horizontal drilling. 


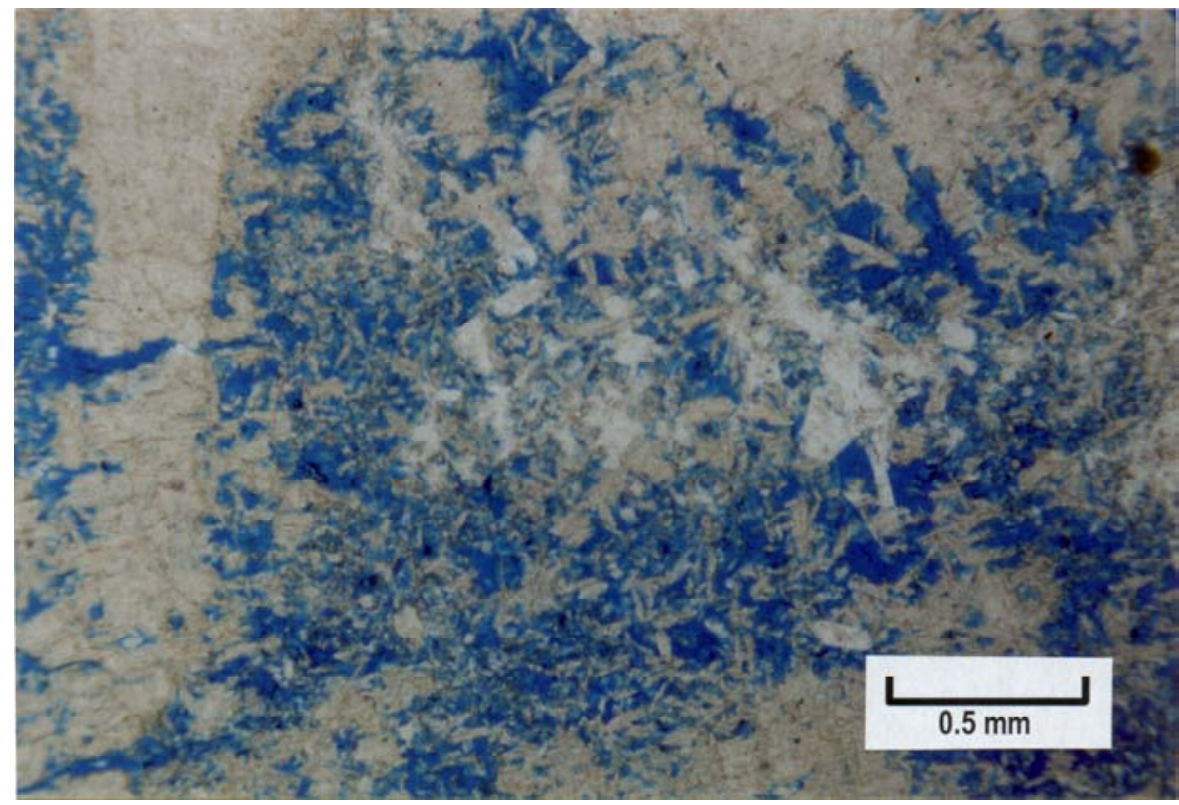

Figure 6. Photomicrograph (plane light with white card technique [diffused light using a piece of paper on the stage of the microscope]) showing a pattern of patchy dolomite dissolution which includes a "micro-box-work" pattern of pores (in blue). Bug No. 10, 6,327.5 feet $(1,928.5 \mathrm{~m})$, porosity $=10.5$ percent, permeability $=7.5$ millidarcies.

\section{ACKNOWLEDGMENTS}

Core and petrophysical data were provided by Burlington Resources, Seeley Oil Company, and Wexpro Company. Jim Parker of the UGS drafted maps and figures. The report was reviewed by David Tabet and Mike Hylland of the UGS. Cheryl Gustin, UGS, formatted the manuscript for publication.

\section{REFERENCES}

Choquette, P.W., and Pray, L.C., 1970, Geologic nomenclature and classification of porosity in sedimentary carbonates: American Association of Petroleum Geologists Bulletin, v. 54, no. 2, p. 207-250.

Crawley-Stewart, C.L., and Riley, K.F., 1993, Cherokee, in Hill, B.G., and Bereskin, S.R., editors, Oil and gas fields of Utah: Utah Geological Association Publication 22, nonpaginated.

Dunham, R.J., 1962, Classification of carbonate rocks according to depositional texture, in Ham, W.E., editor, Classification of carbonate rocks: American Association of Petroleum Geologists Memoir 1, p. 108-121.

Embry, A.R., and Klovan, J.E., 1971, A Late Devonian reef tract on northeastern Banks Island, Northwest Territories: Canadian Petroleum Geologists Bulletin, v. 19, p. 730-781.

Harr, C.L., 1996, Paradox oil and gas potential of the Ute Mountain Ute Indian Reservation, in Huffman, A.C., Jr., Lund, W.R., and Godwin, L.H., editors, Geology of the Paradox basin: Utah Geological Association Publication 25, p. 13-28. 
Harry, D.L., and Mickus, K.L., 1998, Gravity constraints on lithopheric flexure and the structure of the late Paleozoic Ouachita orogen in Arkansas and Oklahoma south-central North America: Tectonics, v. 17, no. 2, p. 187-202.

Hintze, L.F., 1993, Geologic history of Utah: Brigham Young University Studies Special Publication 7, $202 \mathrm{p}$.

Hite, R.J., Anders, D.E., and Ging, T.G., 1984, Organic-rich source rocks of Pennsylvanian age in the Paradox Basin of Utah and Colorado, in Woodward, Jane, Meissner, F.F., and Clayton, J.L., editors, Hydrocarbon source rocks of the greater Rocky Mountain region: Rocky Mountain Association of Geologists Guidebook, p. 255-274.

Kluth, C.F., 1986, Plate tectonics of the Ancestral Rocky Mountains: American Association of Petroleum Geologists Memoir 41, p. 353-369.

Kluth, C.F., and Coney, P.J., 1981, Plate tectonics of the Ancestral Rocky Mountains: Geology, v. 9 , p. 10-15.

Martin, G.W., 1983, Bug, in Fassett, J.E., editor, Oil and gas fields of the Four Corners area, volume III: Four Corners Geological Society, p. 1073-1077.

Nuccio, V.F., and Condon, S.M., 1996, Burial and thermal history of the Paradox Basin, Utah and Colorado, and petroleum potential of the Middle Pennsylvanian Paradox Formation, in Huffman, A.C., Jr., Lund, W.R., and Godwin, L.H., editors, Geology of the Paradox Basin: Utah Geological Association Publication 25, p. 57-76.

Oline, W.F., 1996, Bug, in Hill, B.G., and Bereskin, S.R., editors, Oil and gas fields of Utah: Utah Geological Association Publication 22 Addendum, non-paginated.

Utah Division of Oil, Gas and Mining, 2003, Oil and gas production report, May: non-paginated. 


\section{APPENDIX}

\section{THIN SECTION PHOTOMICROGRAPHS AND DESCRIPTIONS, CHEROKEE AND BUG FIELDS, SAN JUAN COUNTY, UTAH}




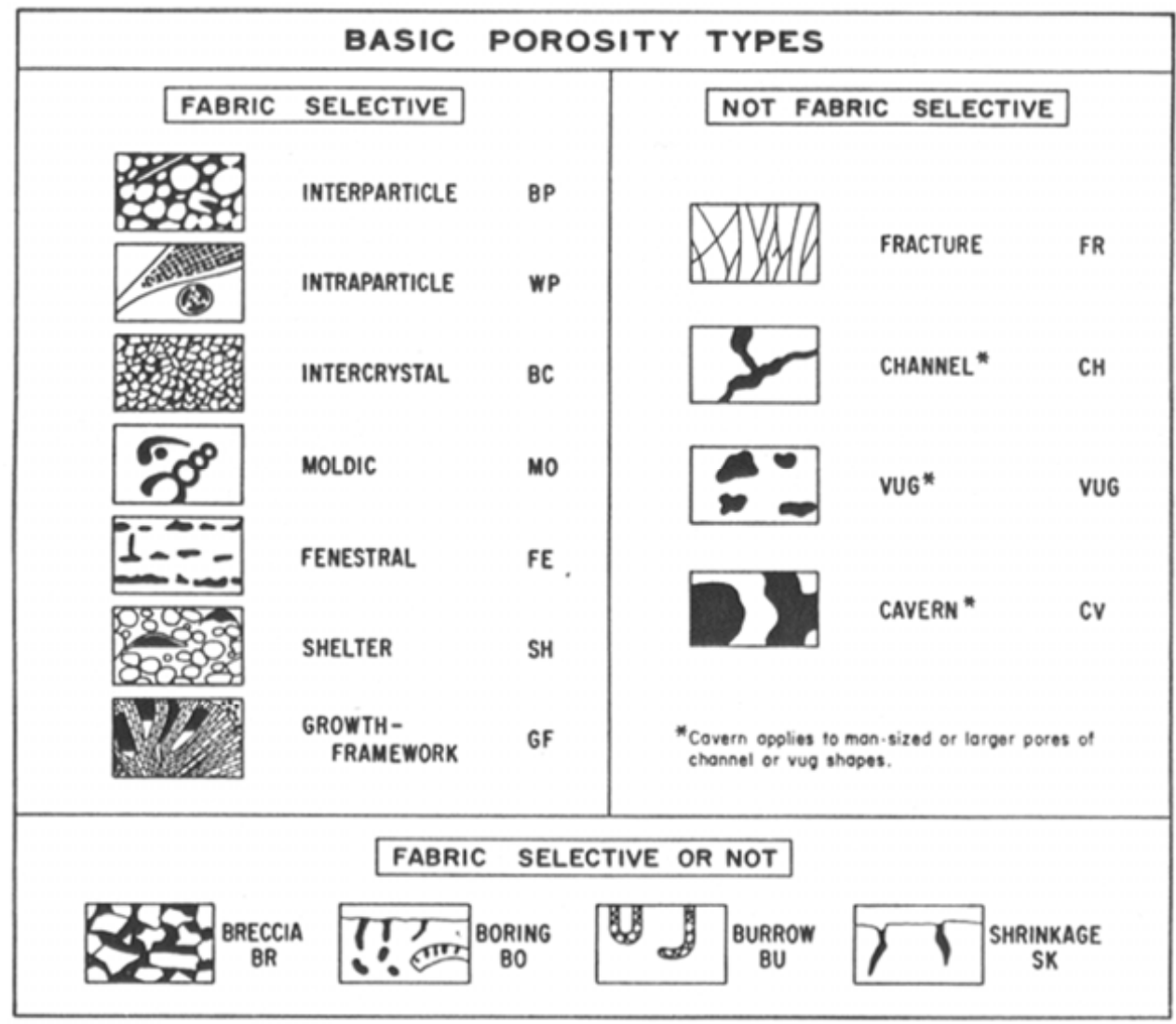

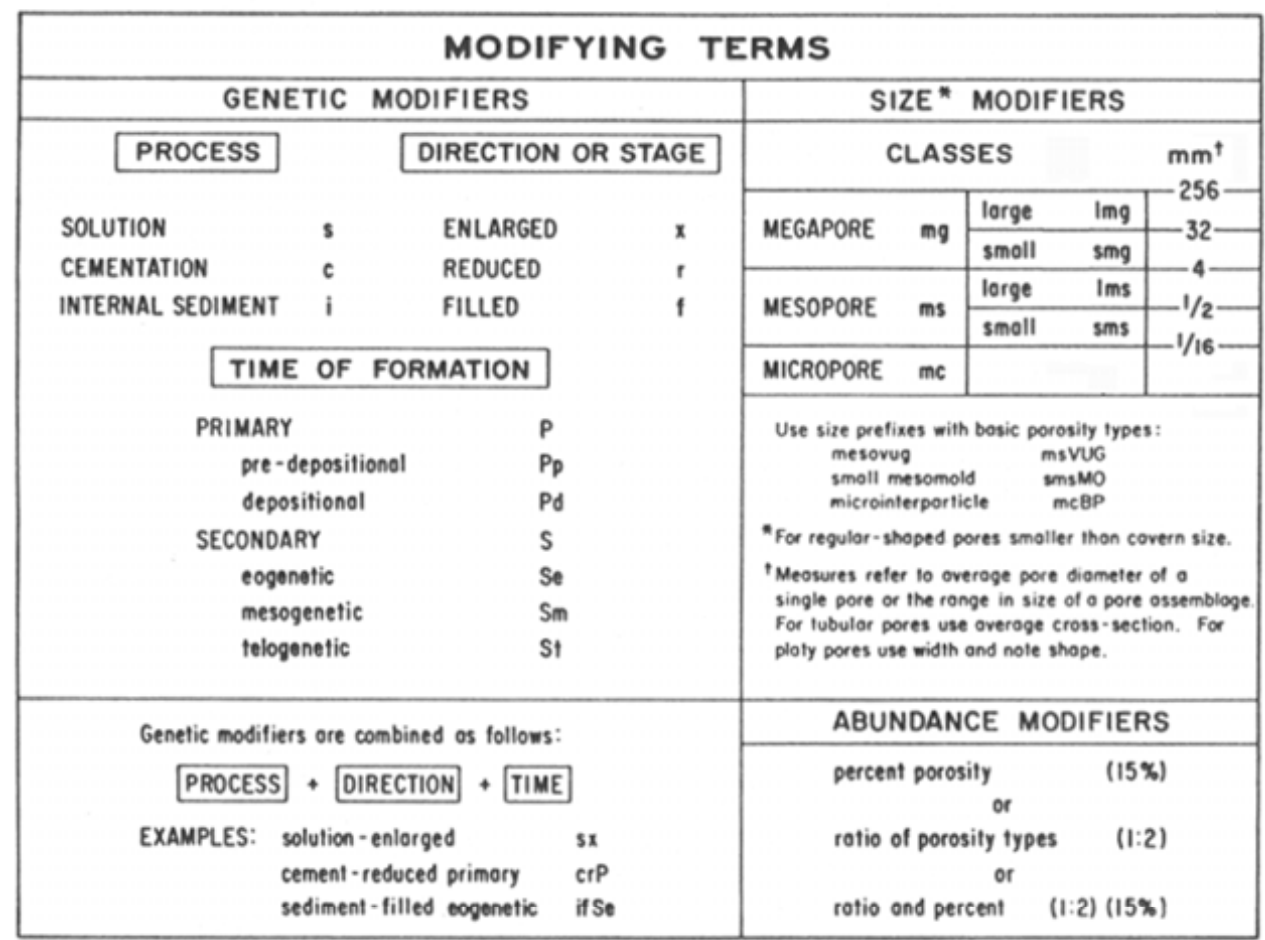

Classification of pores and pore systems in carbonate rocks (Choquette and Pray, 1970). Abbreviations of basic porosity types are used in thin section descriptions. 


\section{CHEROKEE 22-14, CHEROKEE FIELD}




\section{$\underline{5,768.7} \mathbf{f t}$.}

Plug:

Description:

Diagenetic events:

Pore Types: $\varnothing-22.9 \%, \mathrm{~K}-215 \mathrm{md}$

dolomite; peloidal, packstone to grainstone, anhydrite replacement of grains and fossils, stylolitic, microporosity is late dissolution postdating stylolites, dissolution front probably early dolomite (hypersaline or mixing zone), shallow water, low sedimentation rate, high energy, hard pellet muds. There were two generations of oil migration - the first was cooked leaving pyrobitumen (solid, thermally altered [cooked out]) bridging micro-BC, then the second generation of oil migrated into the smaller pore throats.

1) early dolomitization/dissolution of undolomitized grains

(molds), 2) stylolitization (pressure solution), 3) late dissolution/microporosity development, 4) anhydrite replacement, 5) bitumen

Mo, micro-BC (microporosity)

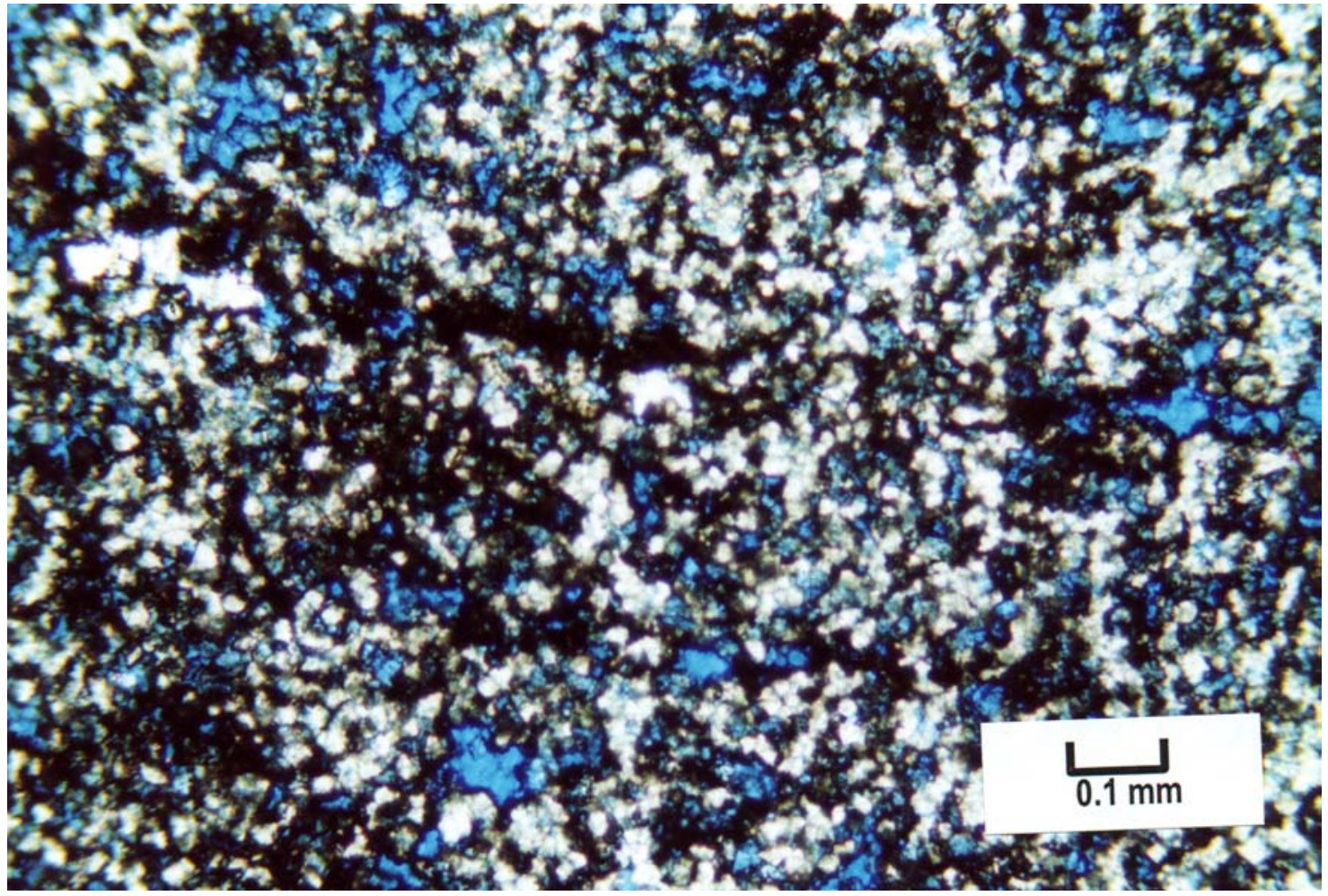




\section{$\underline{5,778.1}$ ft.}

Plug :

Description:

Diagenetic events:

Pore Types: $\varnothing-15.4 \%, \mathrm{~K}-1.4 \mathrm{md}$

dolomite, wackestone to mudstone, patchy microporosity (late solution event?), fractures (healed with anhydrite, open filled with bitumen), soft pellet mud facies, low energy, subtidal, accumulation fast, (check for source rock/kerogen).

1) dolomitization, 2) late dissolution microporosity, 3) fracturing. micro-BC

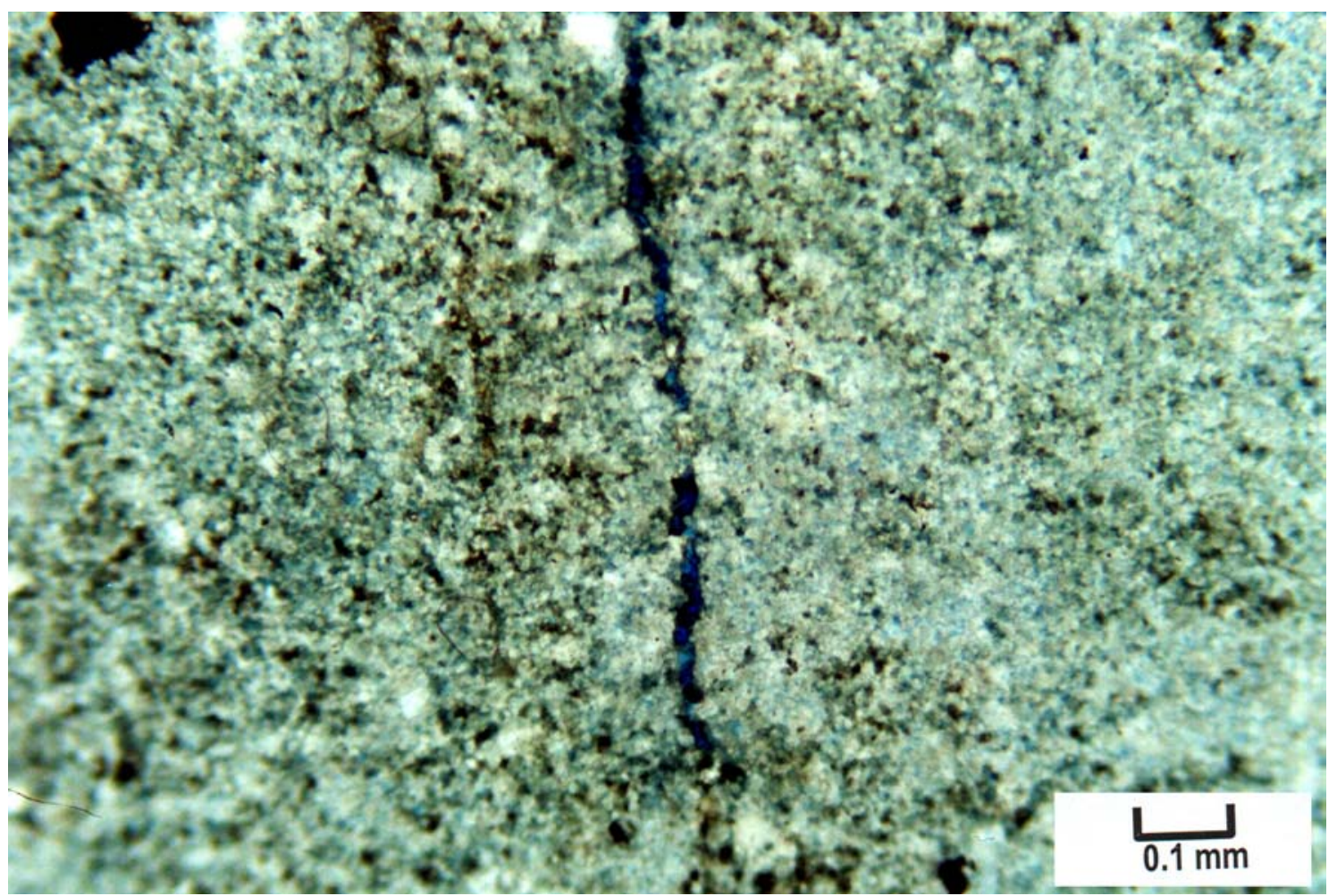




\section{$\underline{5,783.0 \mathrm{ft}}$}

Plug:

Description:

$\varnothing-21.9 \%, \mathrm{~K}-21.0 \mathrm{md}$

Diagenetic events:

dolomite (tight), packstone to wackestone, with anhydrite replacement, peloids, crinoids, bryozoans, dissolution fronts with auto breccia fabric, some solution enlarged molds and channels, open marine, silicification with fibrous chert replacing anhydrite.

1) early dolomitization, 2) late solution enlarged microporosity along dissolution fronts, 3) anhydrite replacement, 4) silicification, 5) bitumen plugging

Pore Types: $\quad$ Mo, micro-BC, $\mathrm{CH}$

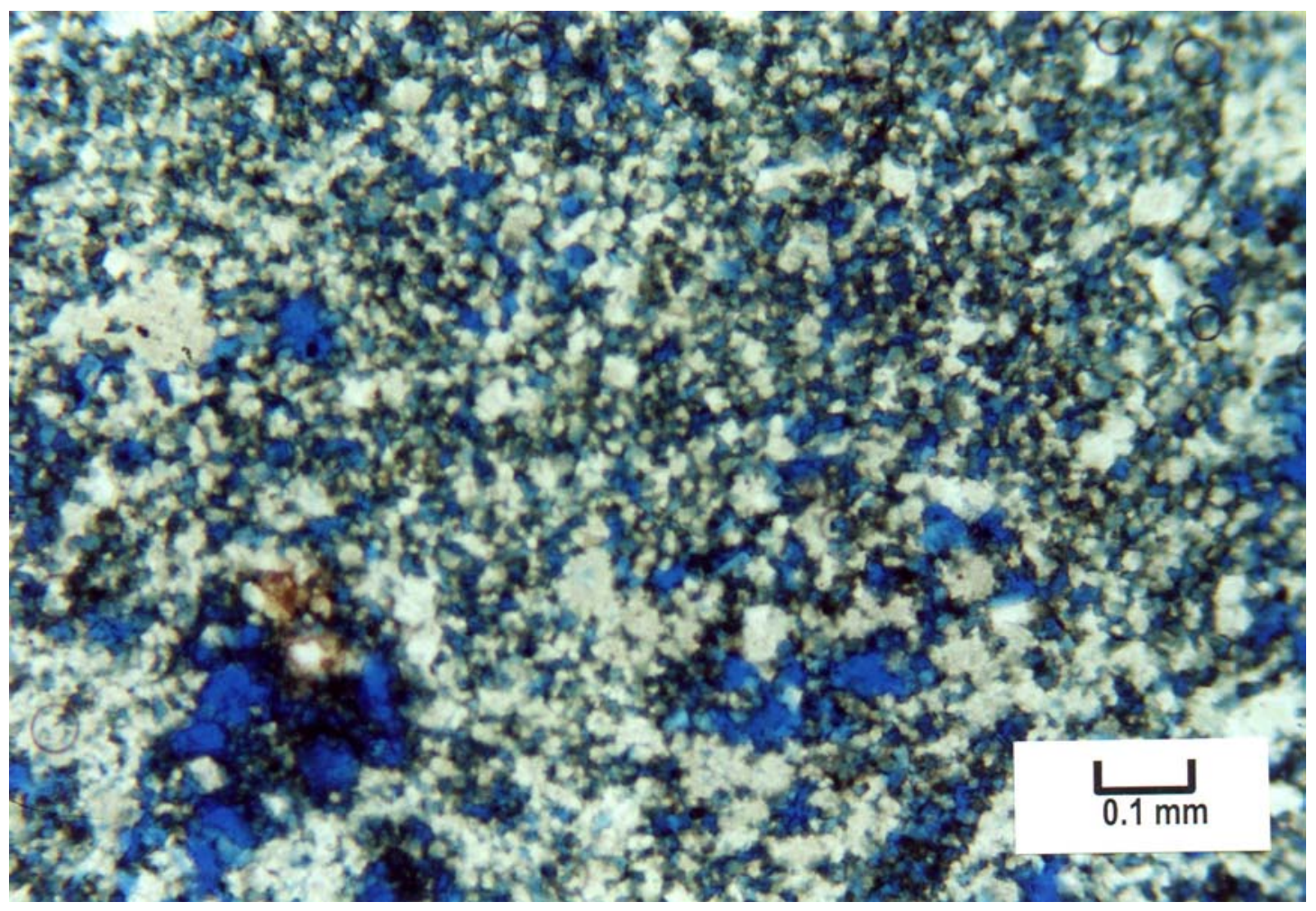



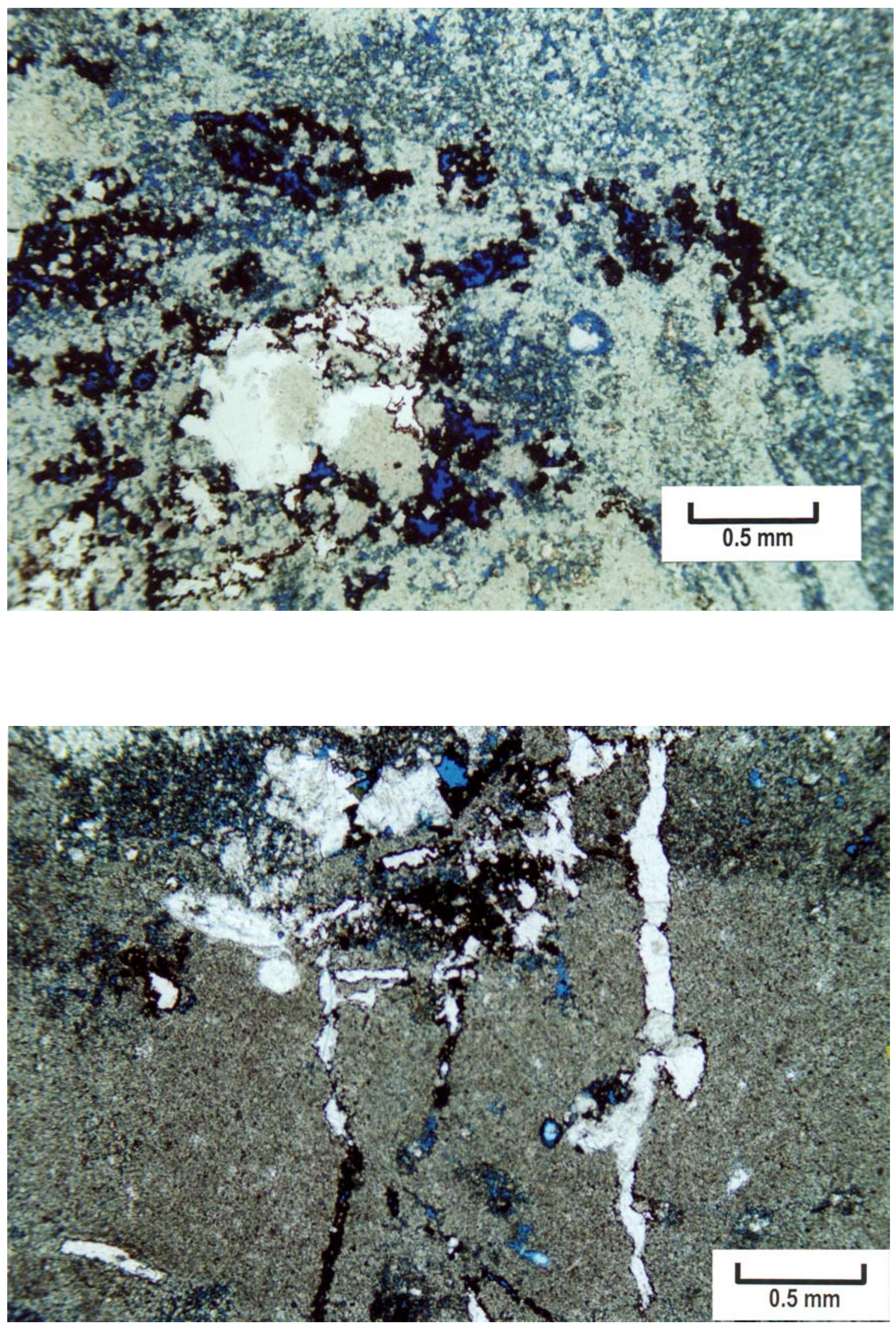


\section{$\underline{5,789.6} \mathbf{f t}$.}
Plug :
$\varnothing-15.5 \%, \mathrm{~K}-7.4 \mathrm{md}$
Description:
calcareous dolomite, packstone to wackestone, peloidal, skeletal, open marine, solution fronts, pseudo-brecciation (similar to 5783.0 ft.), late burial patchy irregular porosity (carbon dioxide bearing fluids from depth possible cause of dissolution).
Diagenetic events: 1) early dolomitizations, 2) late dissolution, 3) late anhydrite plugging/replacement, 4) bitumen plugged?
Pore Types: micro-BC, irregular $\mathrm{CH}$, some open fractures

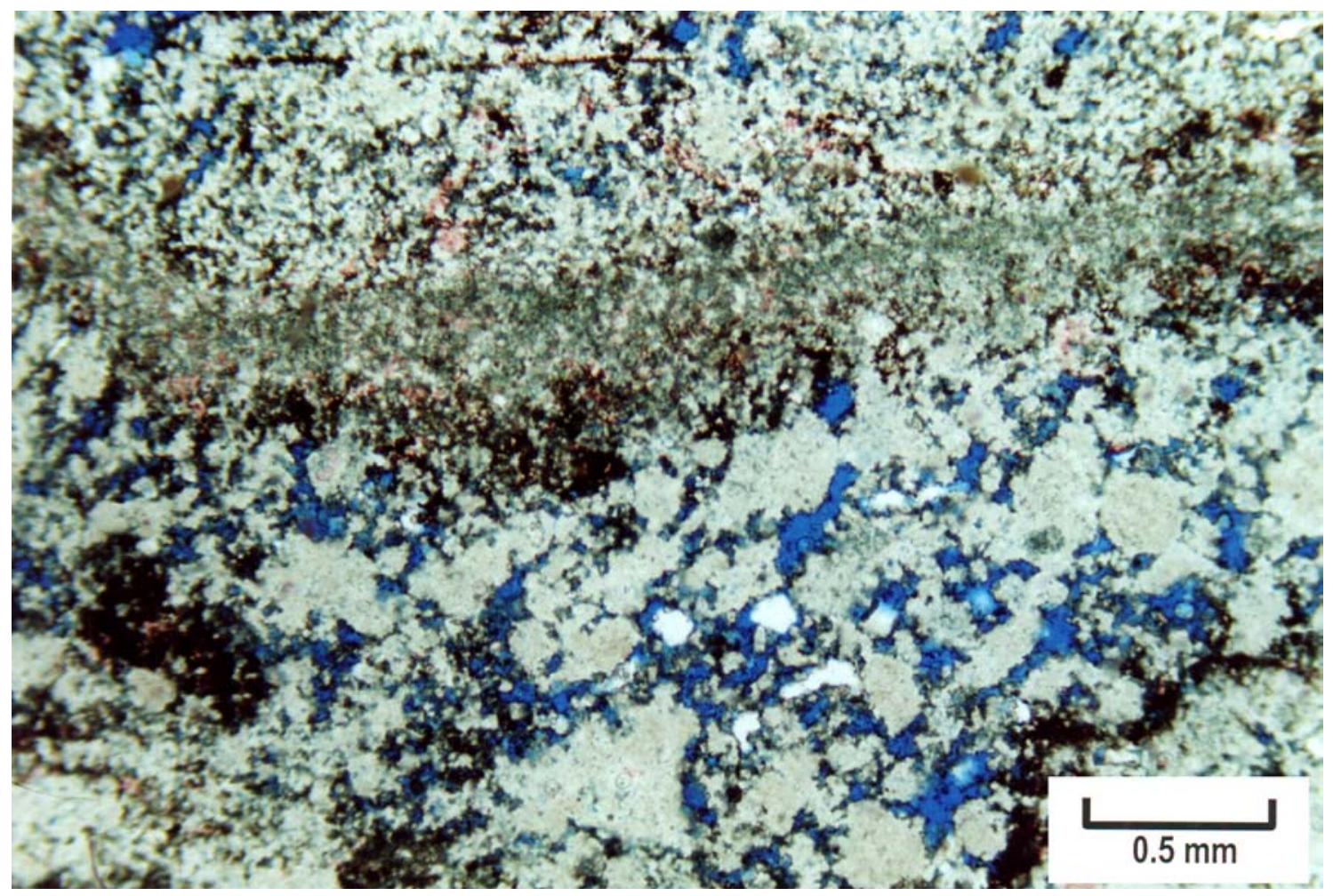




\section{$\underline{5,791.1} \mathbf{f t}$.}

Plug:

Description:

Diagenetic events:

Pore Types: $\varnothing-14.1 \%, \mathrm{~K}-3.1 \mathrm{md}$

calcareous dolomite, packstone to wackestone, crinoidal, patchy microporosity, and irregular solution enlarged channels, microporosity is impregnated with bitumen, pseudo brecciated (late dissolution feature, appears as phylloidal but not), similar to $5789.6 \mathrm{ft}$. but less in anhydrite and more bitumen.

1) early dolomitization, 2) late dissolution, 3) late anhydrite plugging/replacement, 4) bitumen plugged.

micro-BC, $\mathrm{CH}$

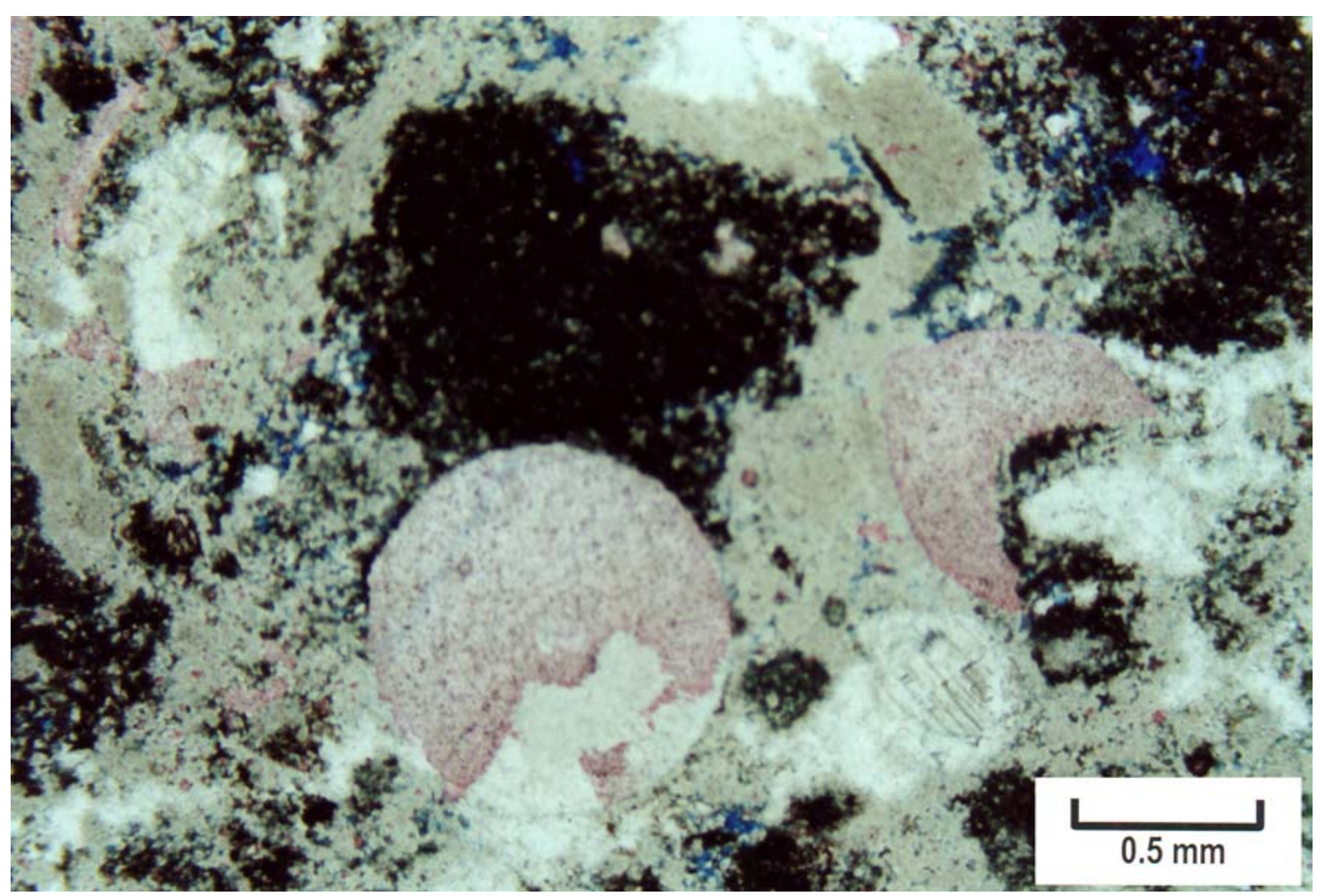




\section{$\underline{5,801.3} \mathbf{f t}$.}

Plug:

Description:

Diagenetic events:

Pore Types: $\varnothing-18.4 \%, \mathrm{~K}-8.3 \mathrm{md}$

dolomitic wackestone, stylolitic, solution front, patchy microporosity with intense bitumen plugging, pseudo brecciation, irregular channel pores, dark clay looking material is bitumen plugging, original fabric $50 \%$, dissolution $50 \%$, late microporosity and dissolution of carbonate by acid from: a) aggressive hydrothermal solutions from depth, b) carbon dioxide escaping from the Mississippian Leadville Limestone, and c) decarboxylation of organic matter.

1) early dolomitization, 2) stylolitization, 3) late dissolution, 4) bitumen plugging

micro-BC, $\mathrm{CH}$

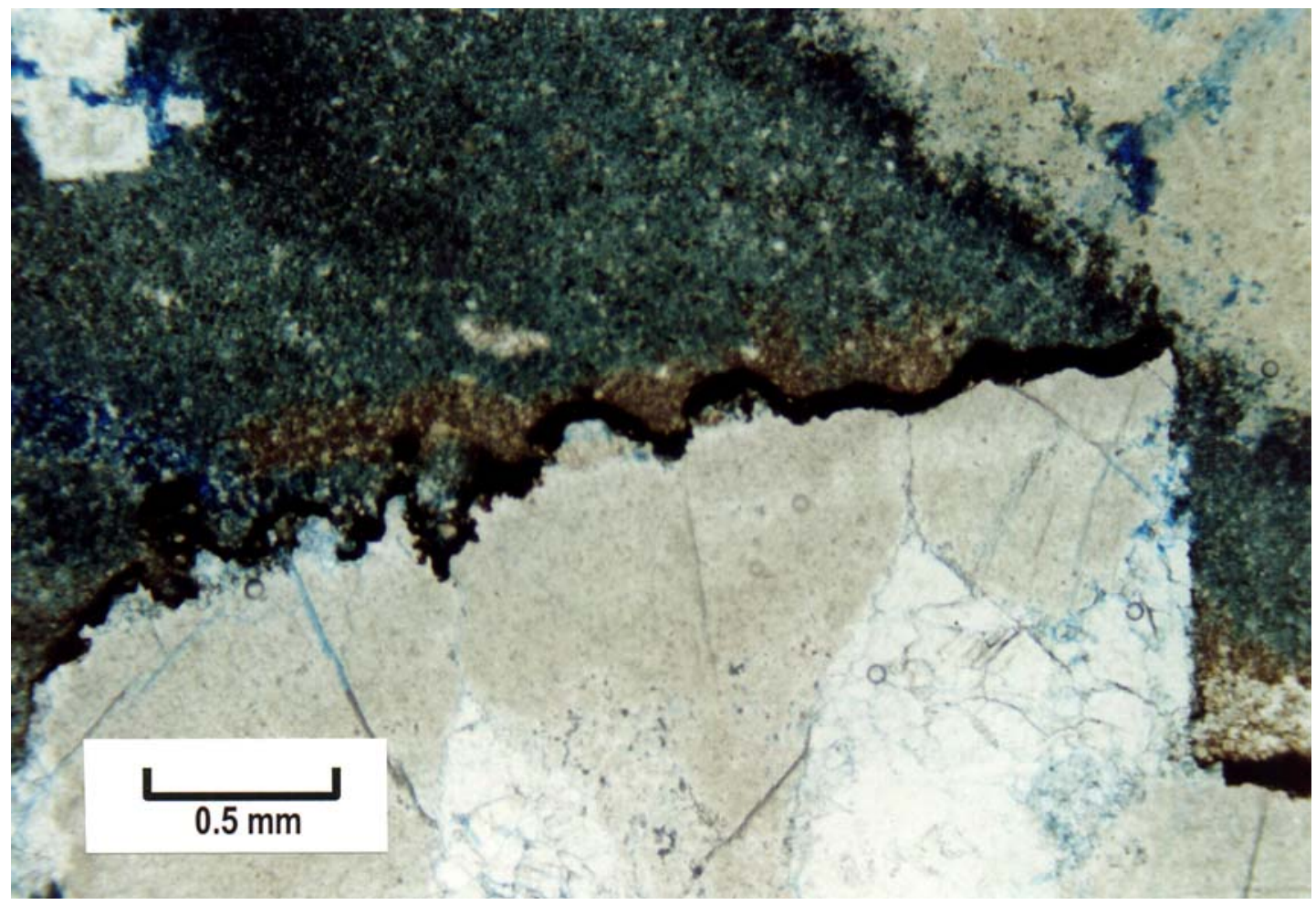




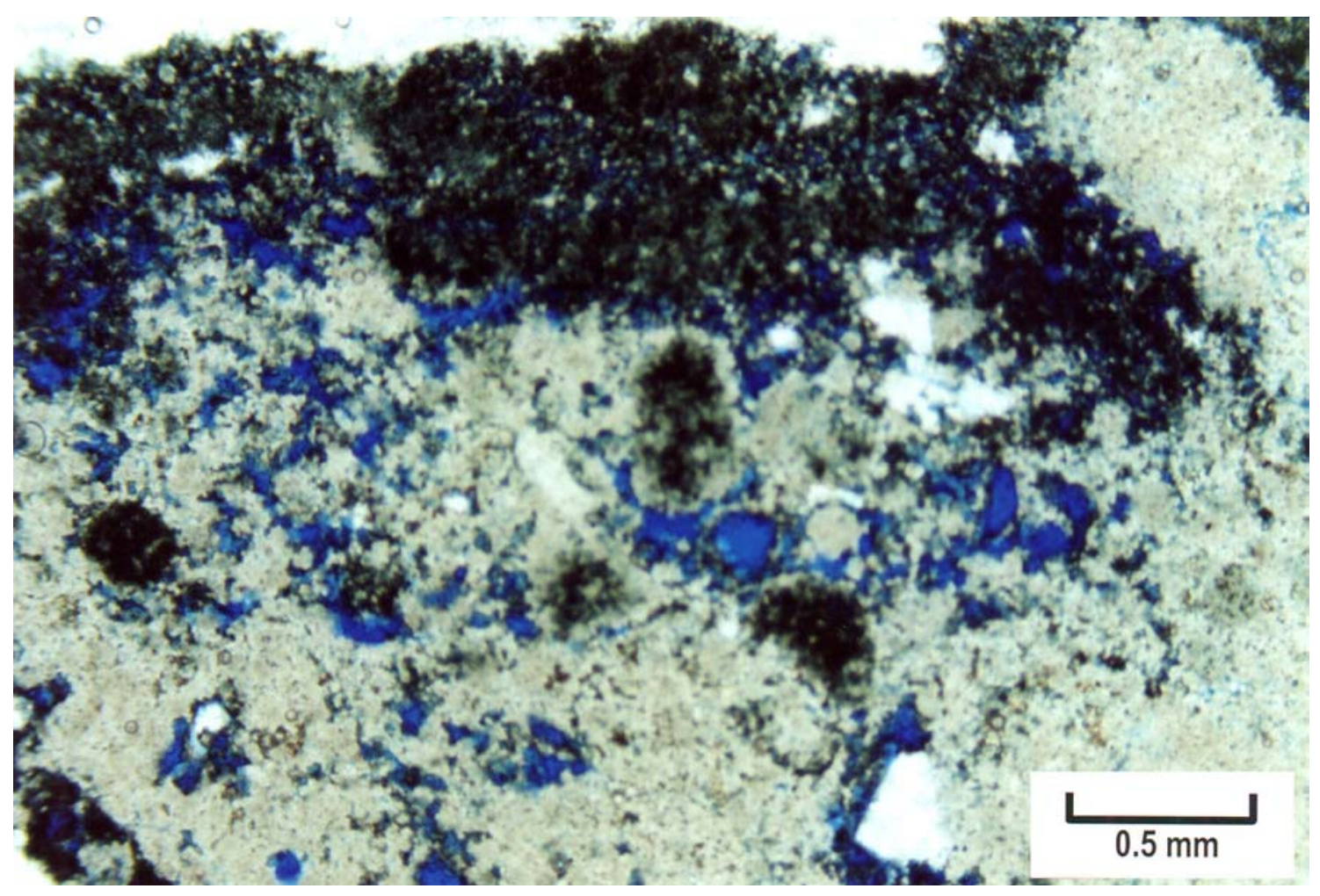




\section{$\underline{5,808.7} \mathbf{f t}$.}

Plug:

Description:

Diagenetic events:

Pore Types: $\varnothing-18.6 \%, \mathrm{~K}-5.1 \mathrm{md}$

dolomite, wackestone to mudstone, pseudo brecciation (not clay rich), solution fronts, irregular microporosity and channels, corroded pseudo clasts of tight original dolomite (solution reflux).

1) early dolomitization (seepage reflux from hypersaline brines), 2) stylolitization from compaction and pressure solution, 3) late dissolution to form microporosity and channel pores, 4) anhydrite plugging and replacement, some silica, 5) bitumen plugging.

micro-BC, $\mathrm{CH}$

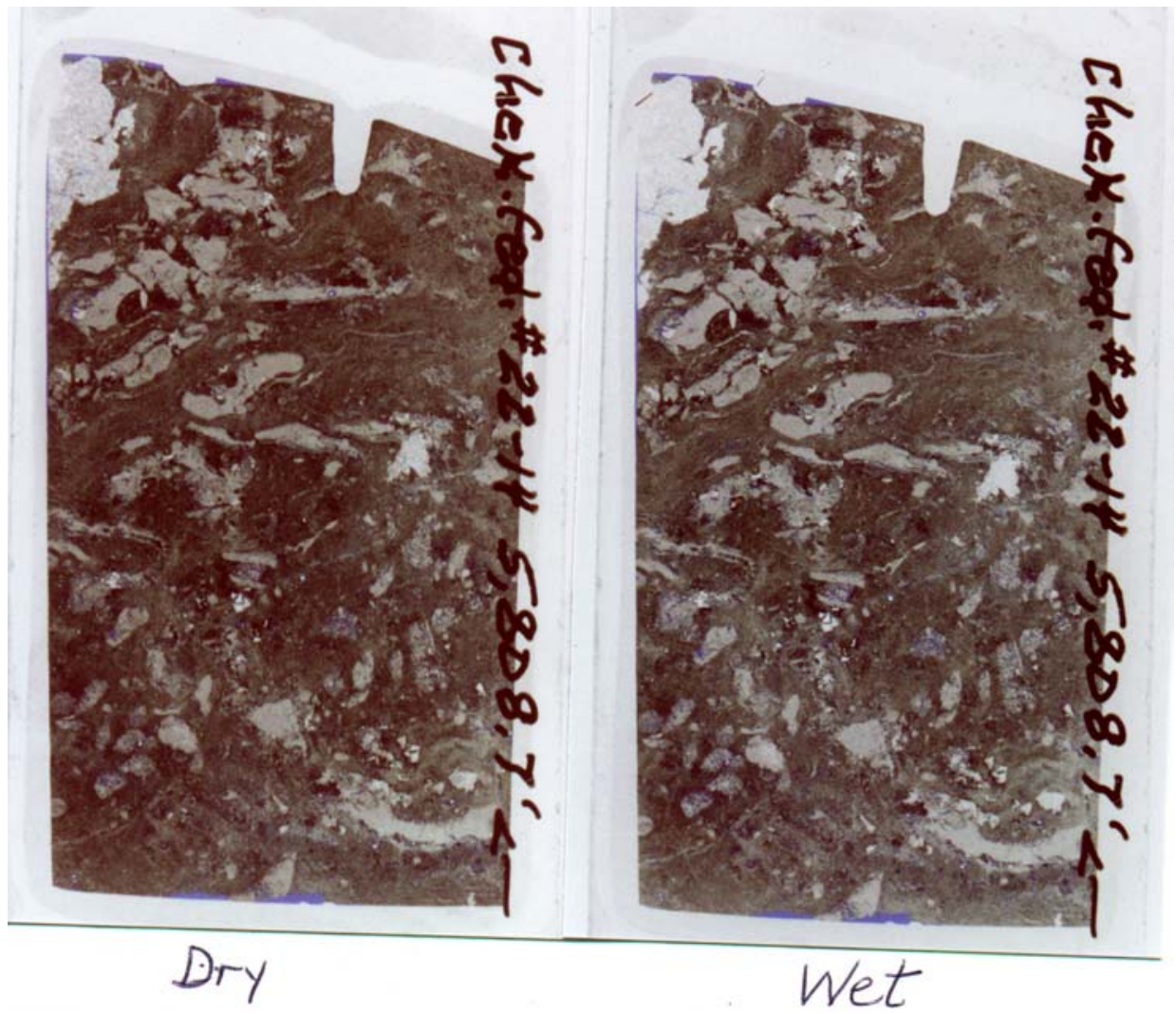




\section{$\underline{5,813.8 \mathrm{ft}}$.}

Plug:

Description:

Diagenetic events:

Pore Types: $\varnothing-19.8 \%, \mathrm{~K}-3.5 \mathrm{md}$

dolomite, wackestone to packstone, uniform microporosity $(90 \%$ with outlying signatures) bitumen plugging, a few channel pores and solution enlarged fractures, pseudo clasts of original dolomite. 1) early dolomitization, 2) late dissolution to form microporosity and channel pores, 3 ) bitumen plugging.

micro-BC, $\mathrm{CH}$

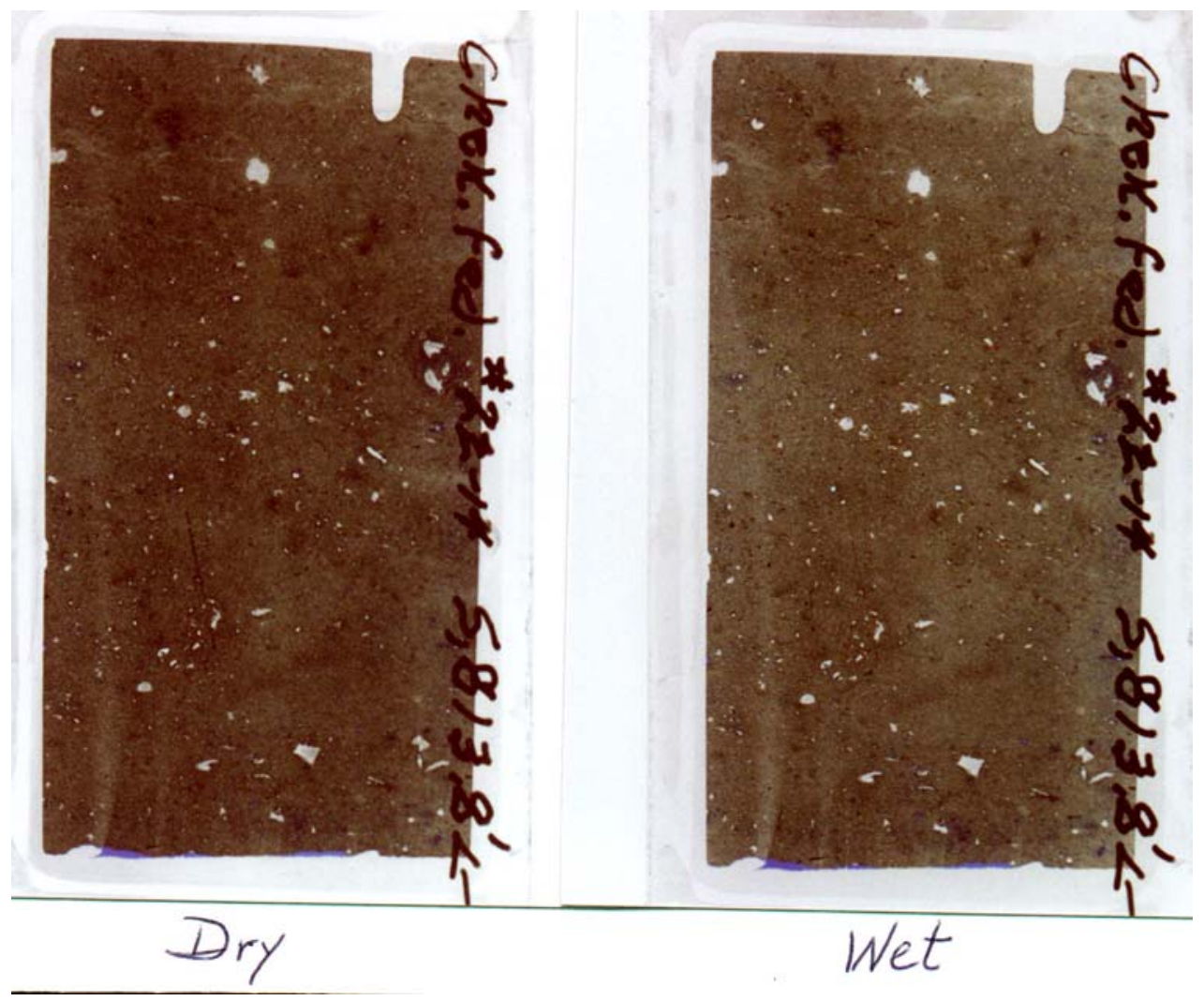




\section{$\underline{5,821.2} \mathbf{f t}$.}

Plug:

Description:

Diagenetic events:

Pore Types: $\varnothing-8.5 \%, \mathrm{~K}-0.79 \mathrm{md}$

dolomitic limestone, phylloidal bafflestone, encrusting forams, fibrous fans of magnesium calcite cement (early marine) along phylloid plates, corroded dissolution porosity in limestone with late anhydrite and bitumen plugging.

1) limestone with primary porosity, 2) early marine cement, 3 ) partial early dolomitization (pre-burial), 4) stylolites, 5) late dissolution, 6) anhydrite plugging, 7) bitumen plugging.

Mo, micro-BC, $\mathrm{CH}$, vugs

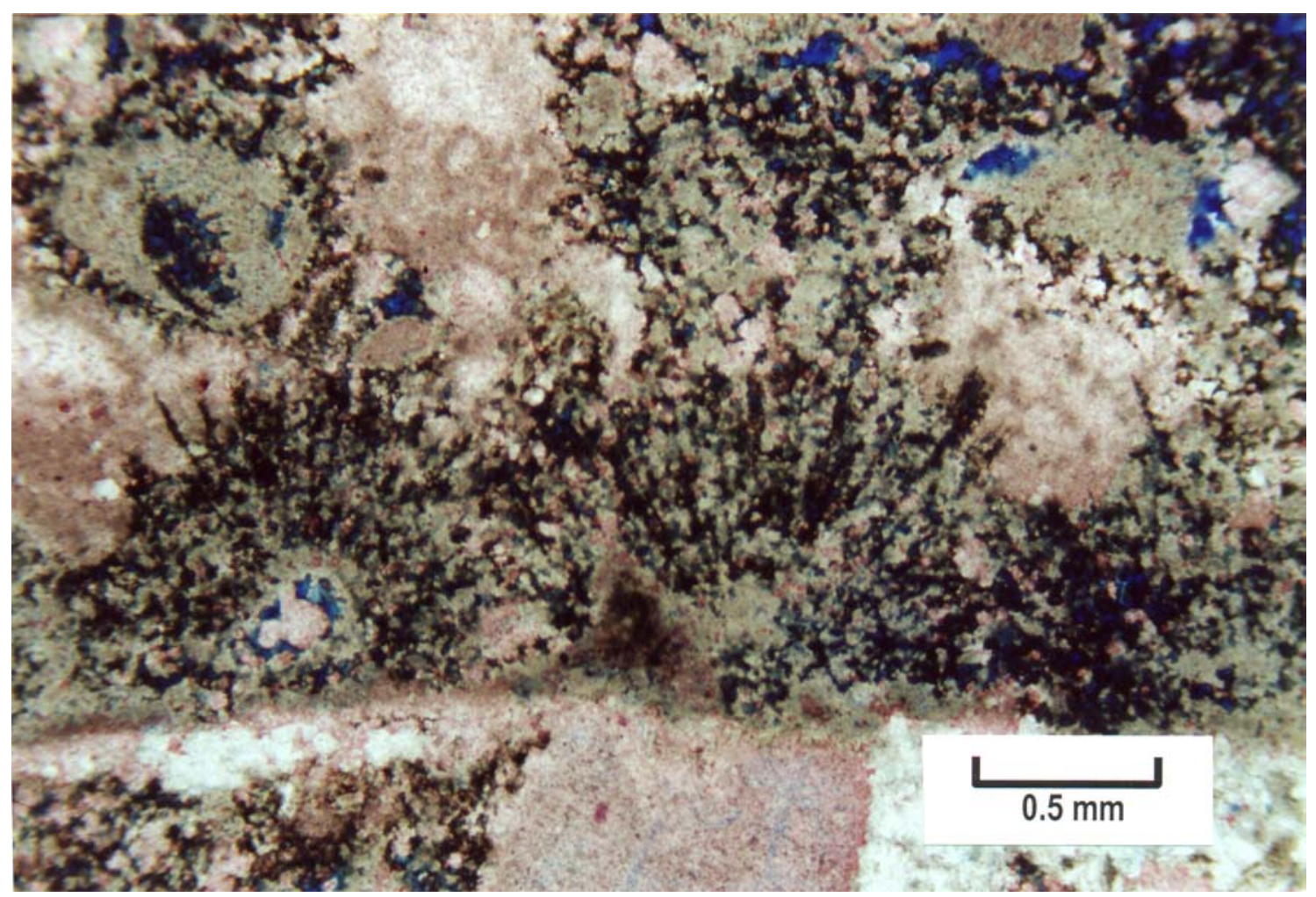




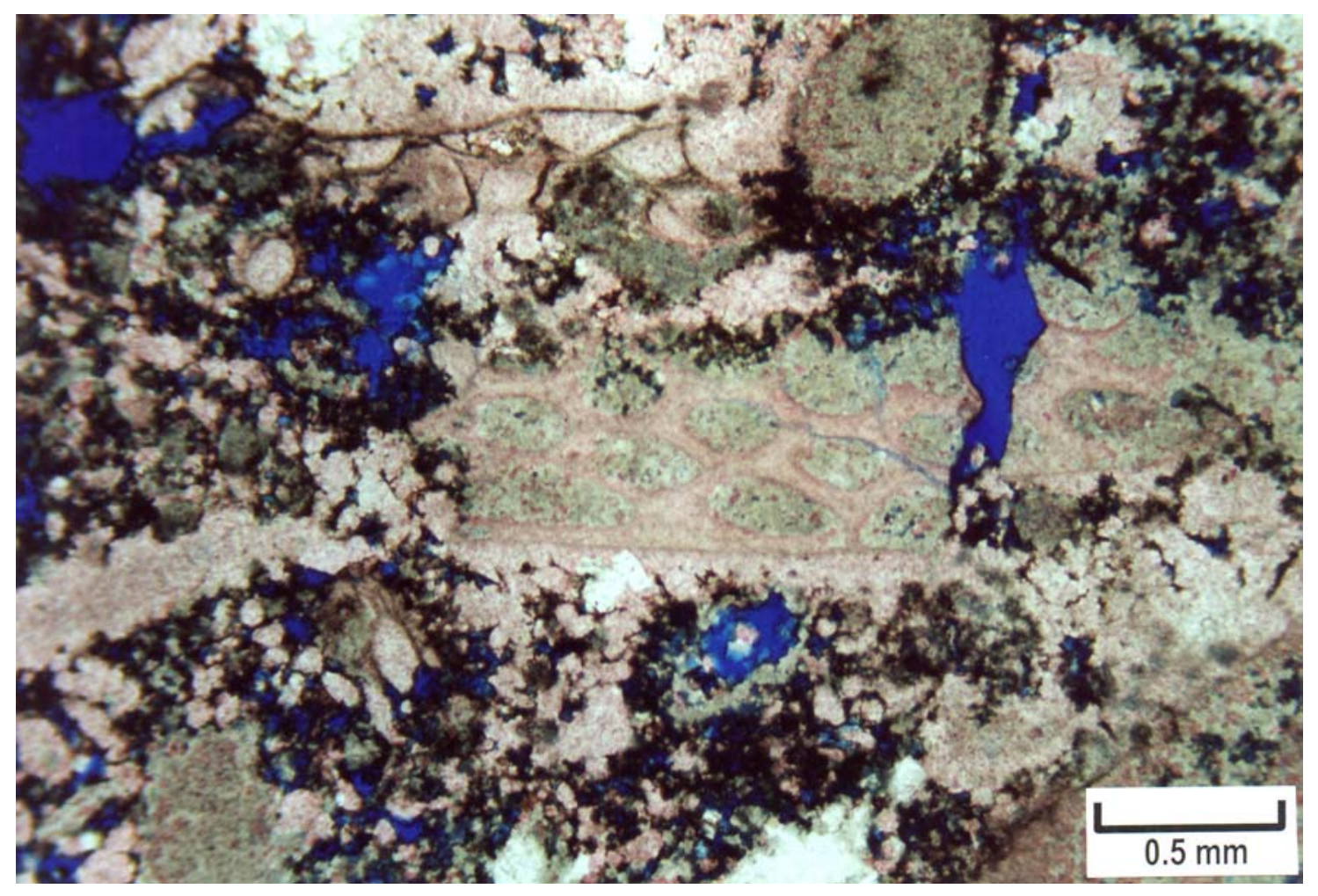




\section{$\underline{5,827.7} \mathbf{f t}$.}

Plug:

Description:

Diagenetic events:

Pore Types: $\varnothing-17.1 \%, \mathrm{~K}-\mathrm{N} . \mathrm{D} .(2$ to $7 \mathrm{md})$

dolomite, wackestone to packstone, corroded dissolution fronts, anhydrite and bitumen plugging.

1) early dolomitization, 2) late dissolution to form microporosity and channel pores, 3) anhydrite plugging, 4) bitumen plugging. Mo, micro-BC, $\mathrm{CH}$

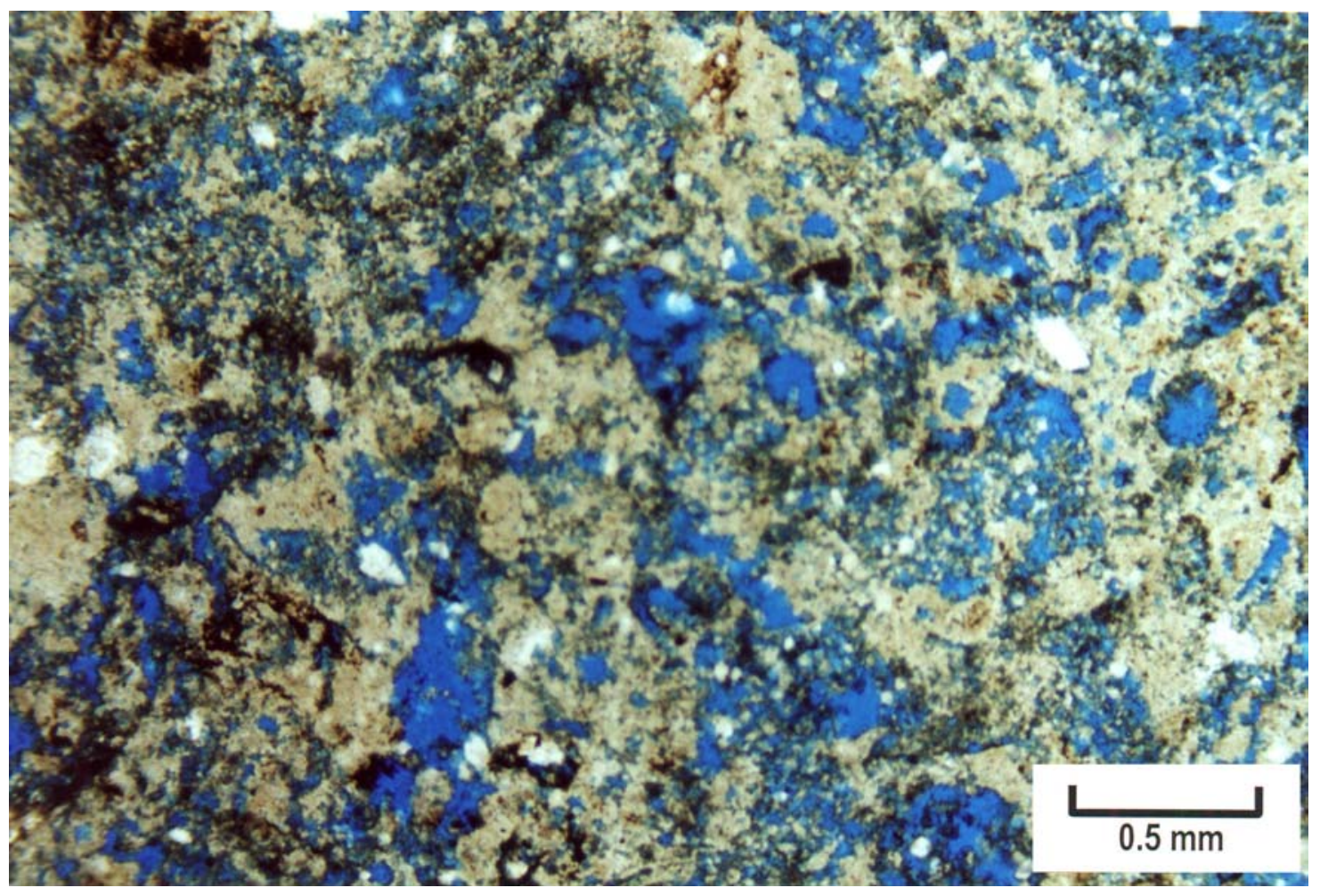




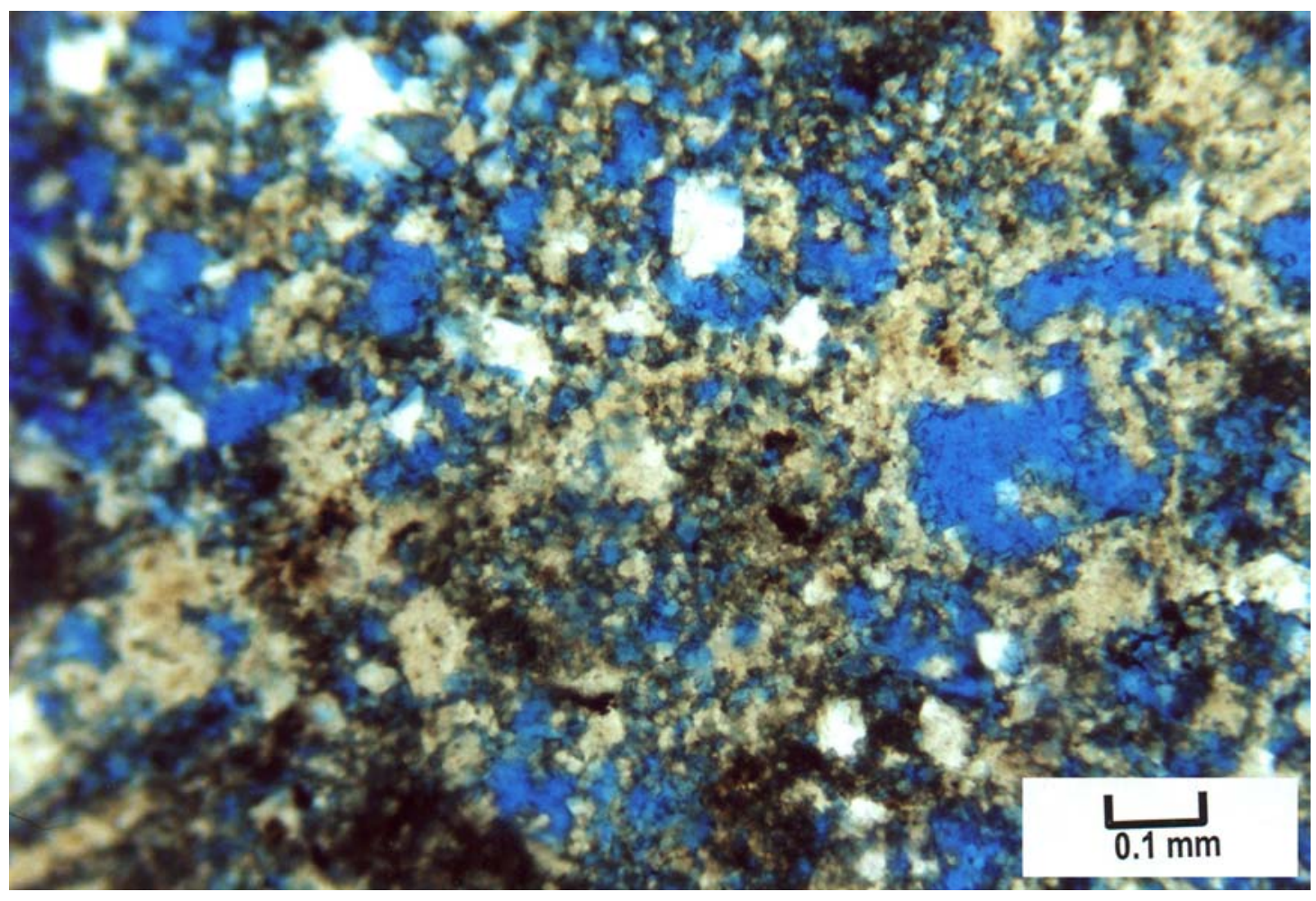




\section{$\underline{5,830.6} \mathbf{f t}$.}

Plug:

Description:

Diagenetic events:

Pore Types: $\varnothing-2.3 \%, \mathrm{~K}-0.04 \mathrm{md}$

fossiliferous limestone, packstone to grainstone, bryozoans, brachiopods, crinoids, coated grains, bethonic forams, fusilinids, open marine facies, compaction stylolites, slightly dolomitic $(<$ $10 \%$ ) (post stylolites), no dissolution or microporosity.

tight

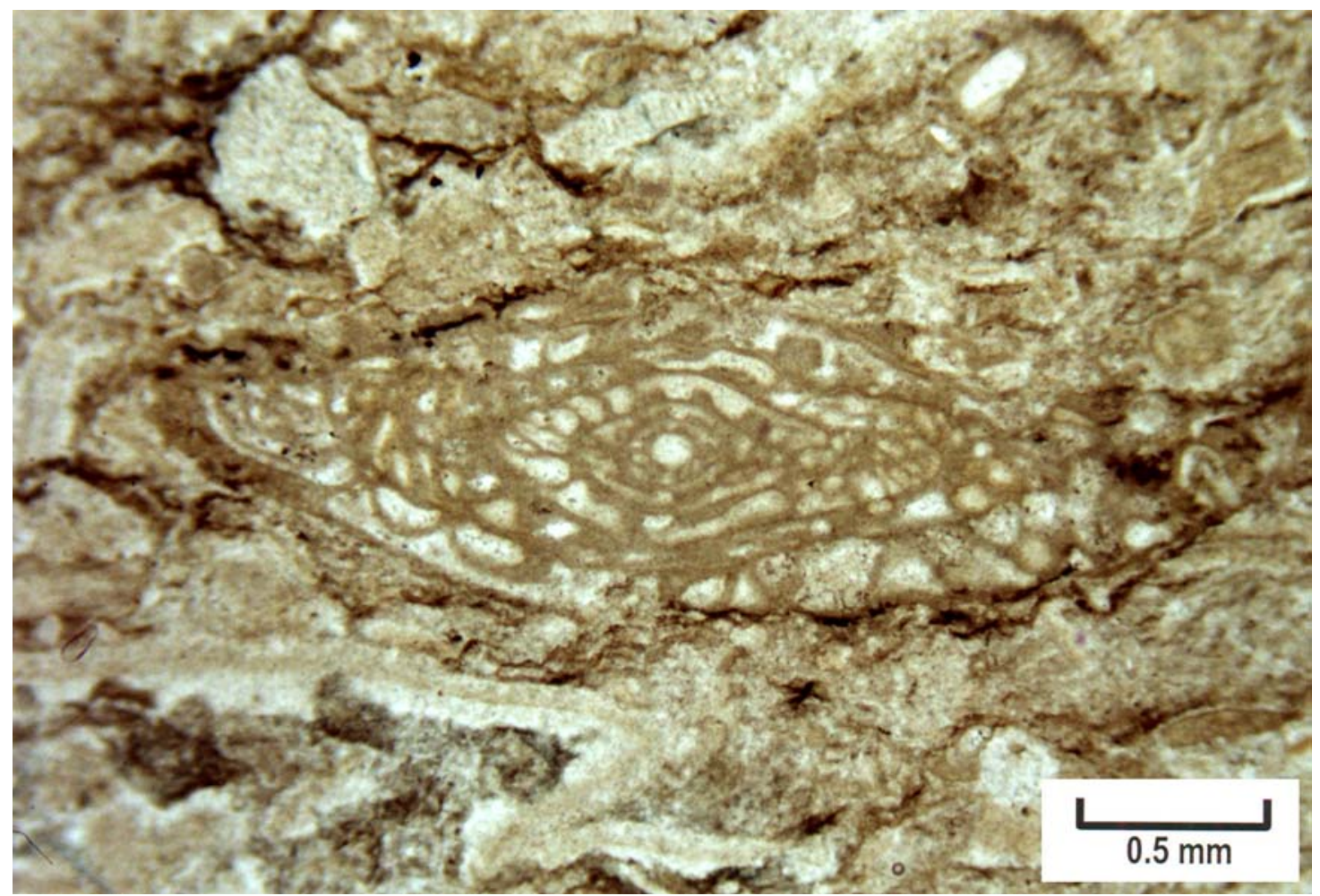



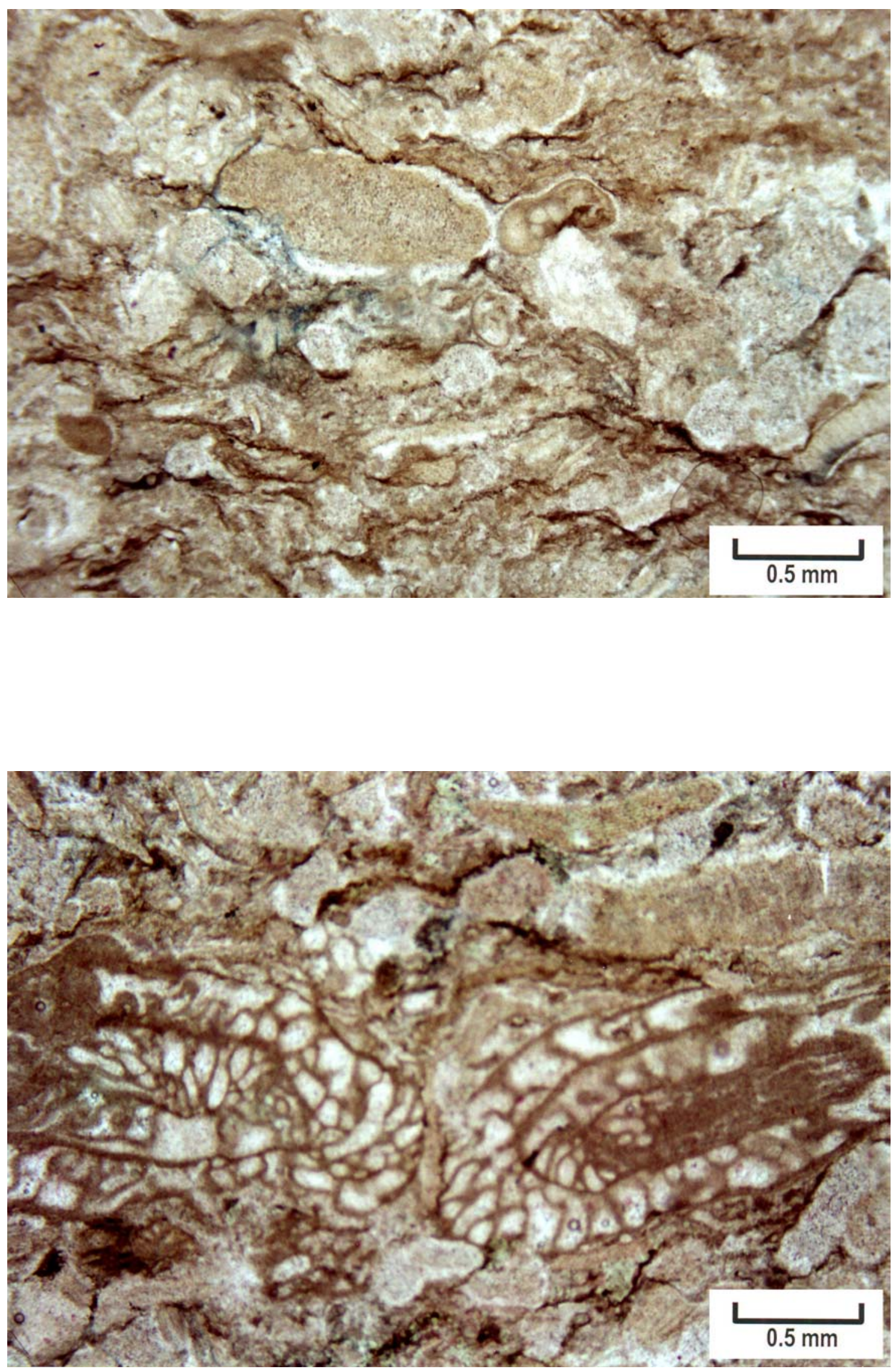


\section{$\underline{5,833.4} \mathbf{f t}$.}

Plug:

Description:

Diagenetic events:

Pore Types: $\varnothing-14.7 \%, \mathrm{~K}-4.7 \mathrm{md}$

skeletal limestone, grainstone, primary porosity, some mixing zone cement, early dissolution molds (some etched later) and dogtoothed spar (meteoric cement), some late patchy dissolution and microporosity, some pseudo-brecciation along dissolution fronts, solution-enlarged fractures, bitumen plugging, a few channel pores and solution enlarged fractures, pseudo clasts of original dolomite. 1) early dissolution, 2) mixing zone dolomitization, 3) dog-tooth sparry cement, 4) late dissolution to form microporosity, 5) late anhydrite plugging, 6) bitumen plugging.

$\mathrm{BP}, \mathrm{WP}, \mathrm{Mo}$, micro-BC, FR

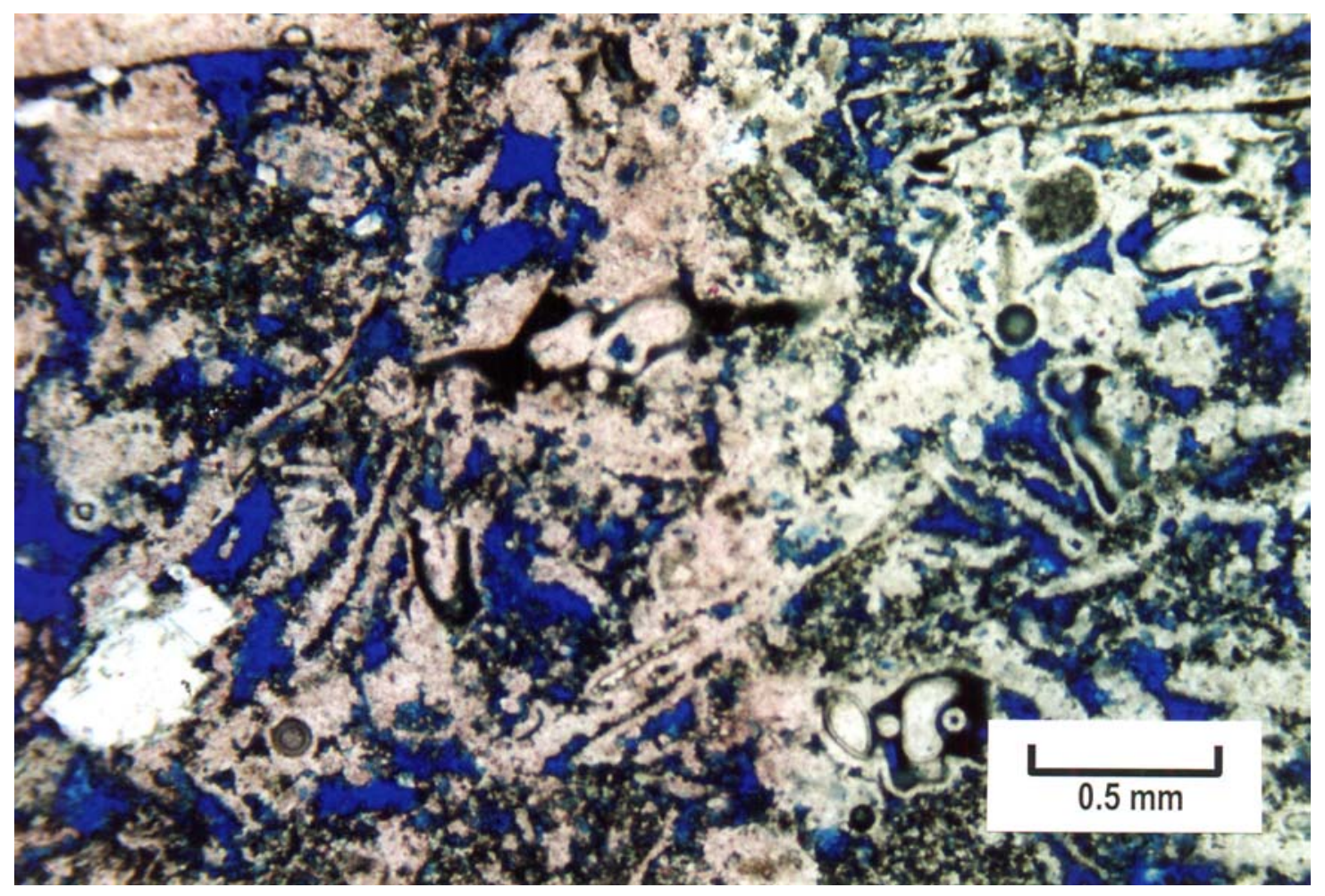



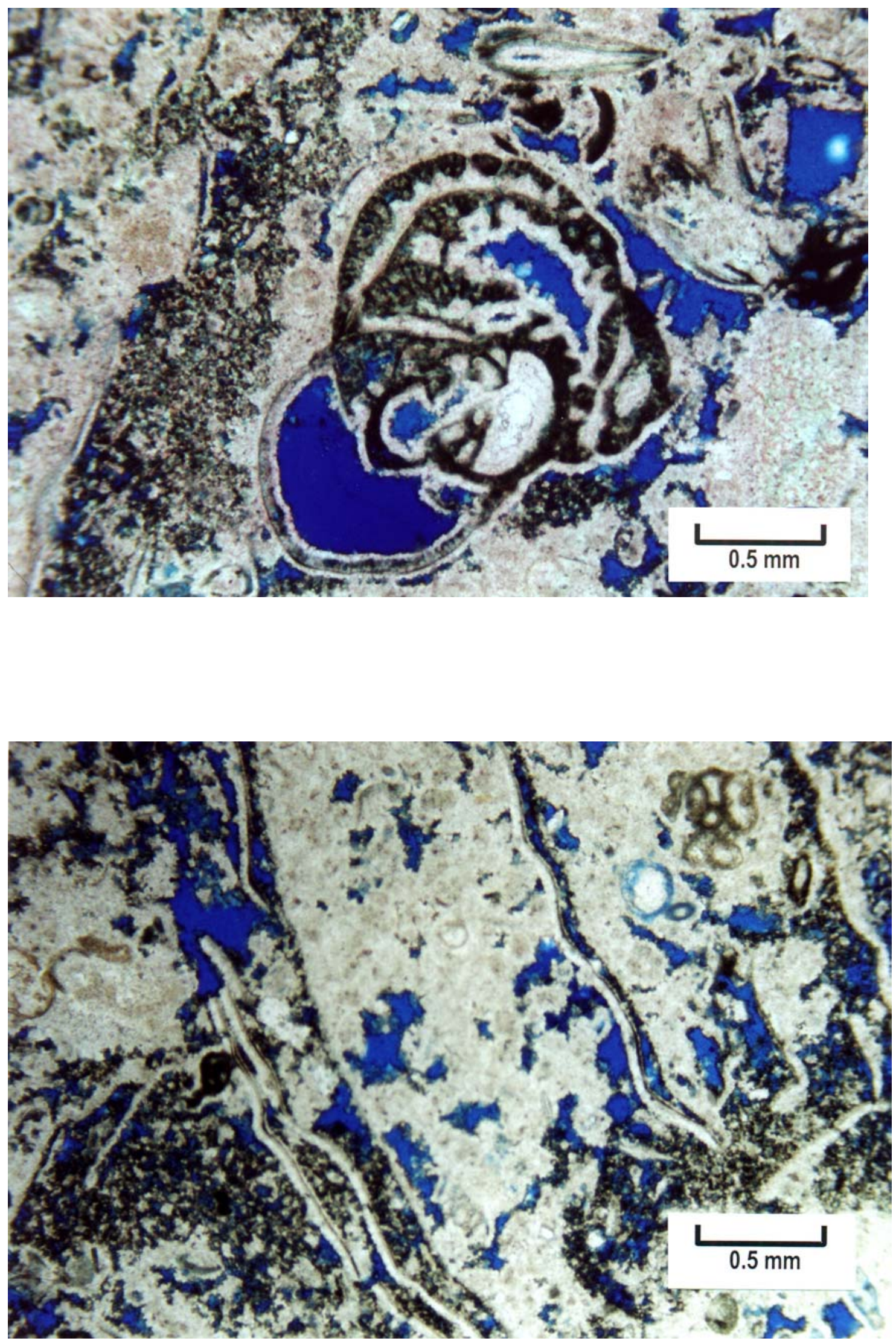


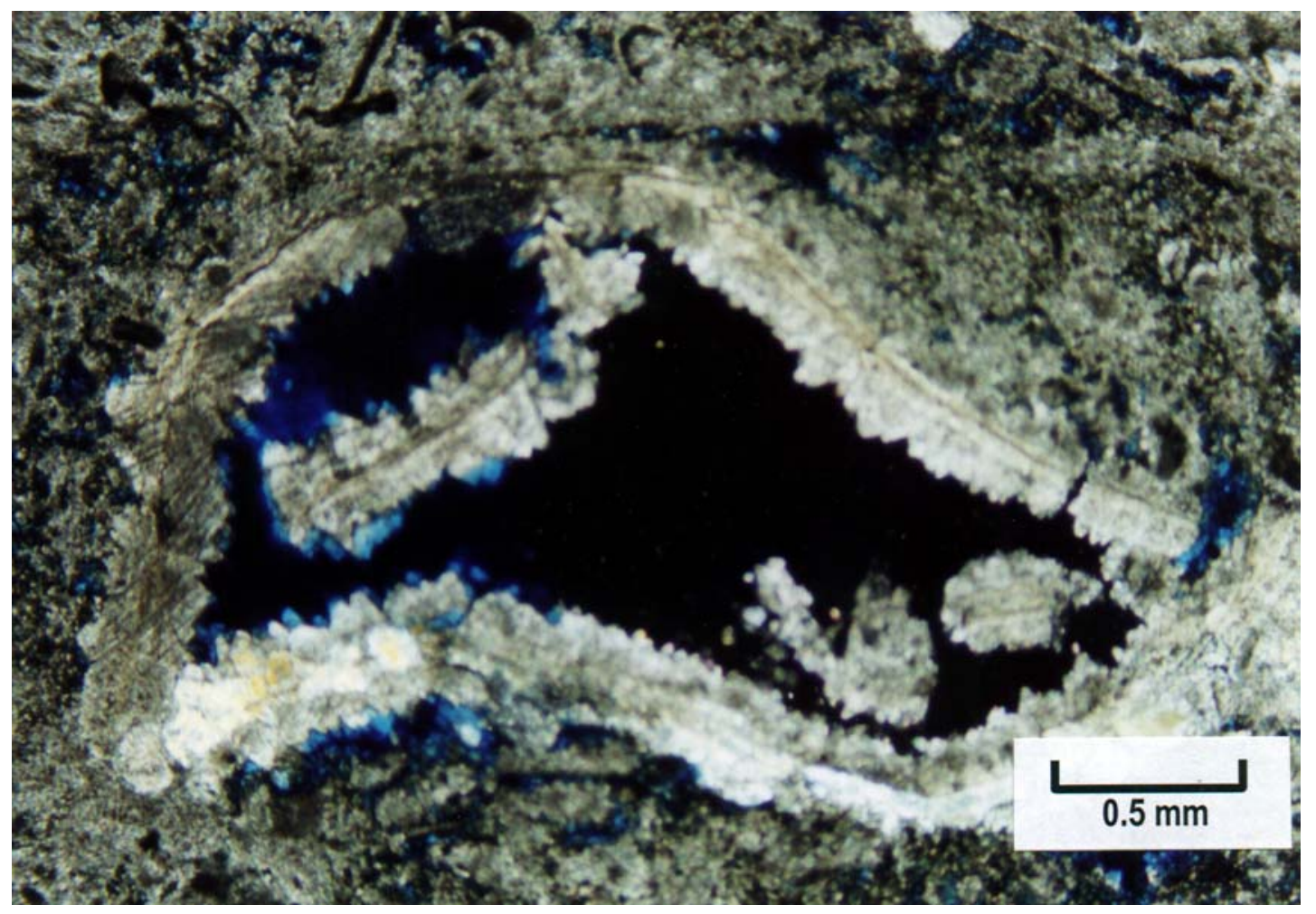




\section{$\underline{5,836.8 \mathrm{ft}}$.}

Plug:

Description:

Diagenetic events:

Pore Types: $\varnothing-9 \%, \mathrm{~K}-2.3 \mathrm{md}$

skeletal phylloid-algal limestone, bafflestone/grainstone, bryozoans, algal plates, echinoderms, interparticle and early moldic porosity with anhydrite plugging early pore space, minimal microporosity, some early syntaxial cements and minor late coarse rhombic dolomite cements growing in molds, no bitumen.

1) early syntaxial cement, 2) early dissolution, 3) late dolomite cementation in pores, and 4) anhydrite plugging.

$\mathrm{BP}, \mathrm{Mo}$, some micro-BC

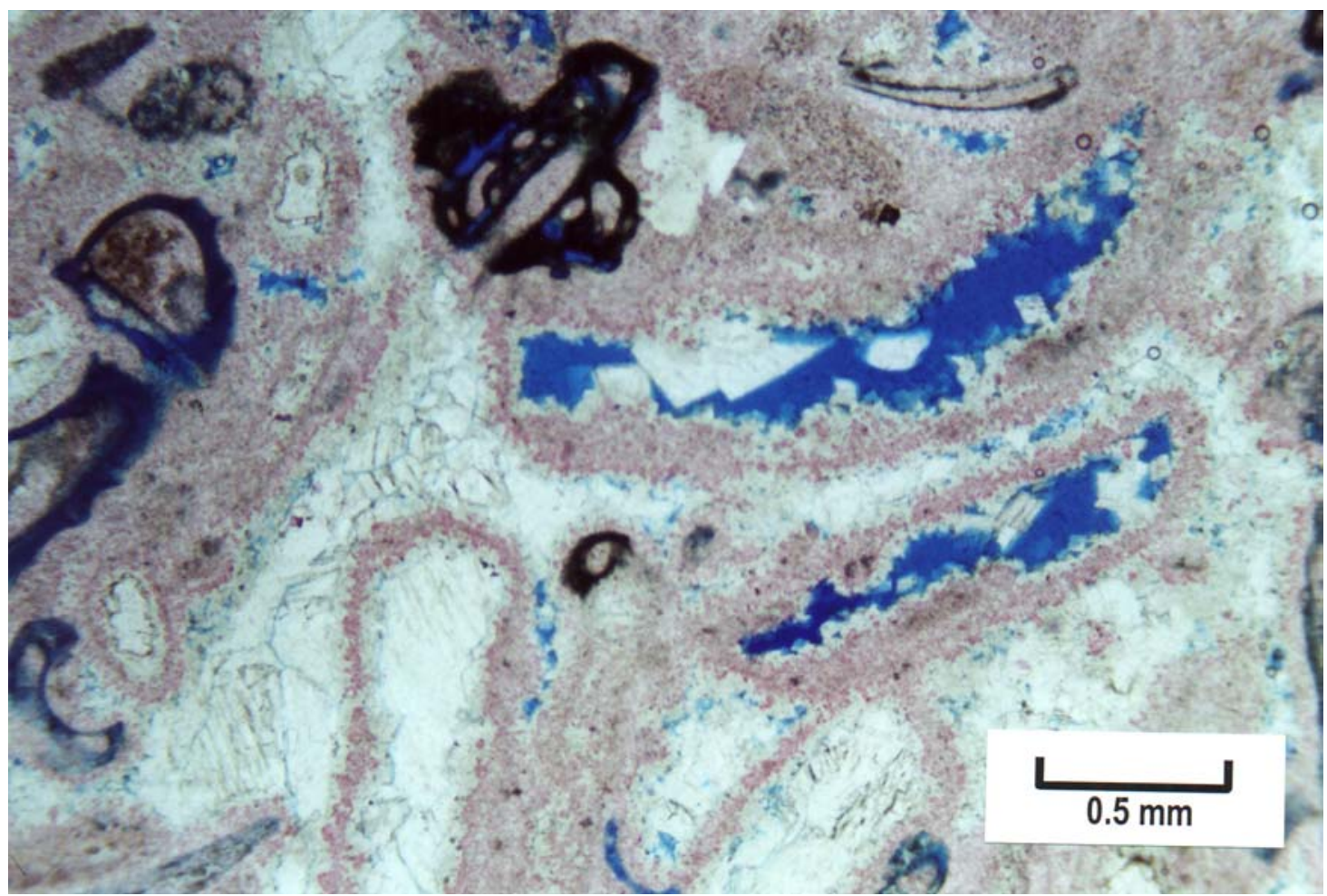




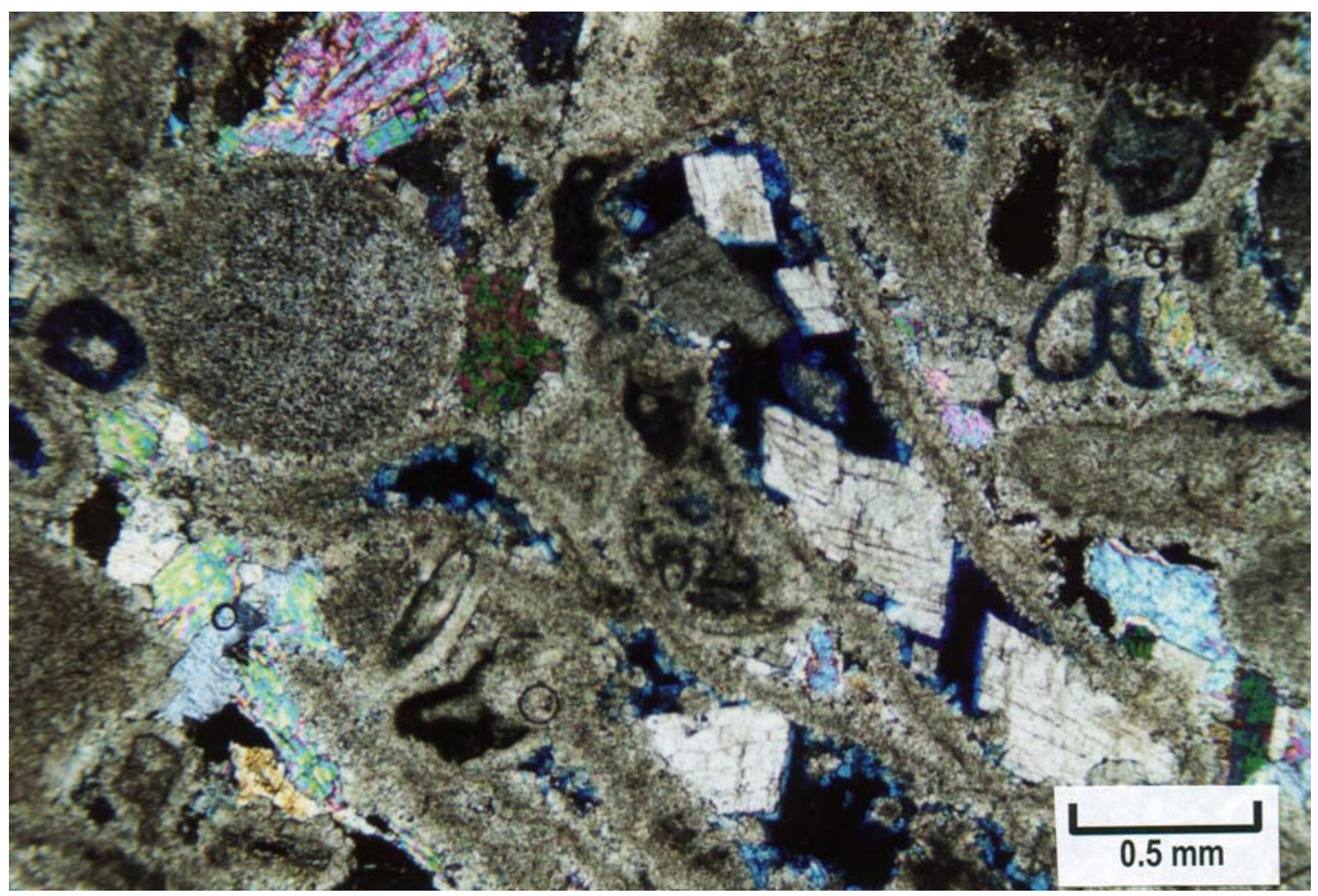




\section{$\underline{5,849.7} \mathbf{f t}$.}

Plug:

Description:

Diagenetic events:

Pore Types: $\varnothing-6.1 \%, \mathrm{~K}-1.4 \mathrm{md}$

phylloid algal limestone, bafflestone, forams (Tetrataxis) around phylloid algal plates, dissolution forming microporosity and channel pores, and solution-enlarged open fractures, and late anhydrite plugging, some bitumen around microporosity.

1) late dissolution to form microporosity, 2) late anhydrite plugging, 3) bitumen plugging.

$\mathrm{BP}, \mathrm{SH}, \mathrm{Mo}$, micro-BC, $\mathrm{CH}$, FR

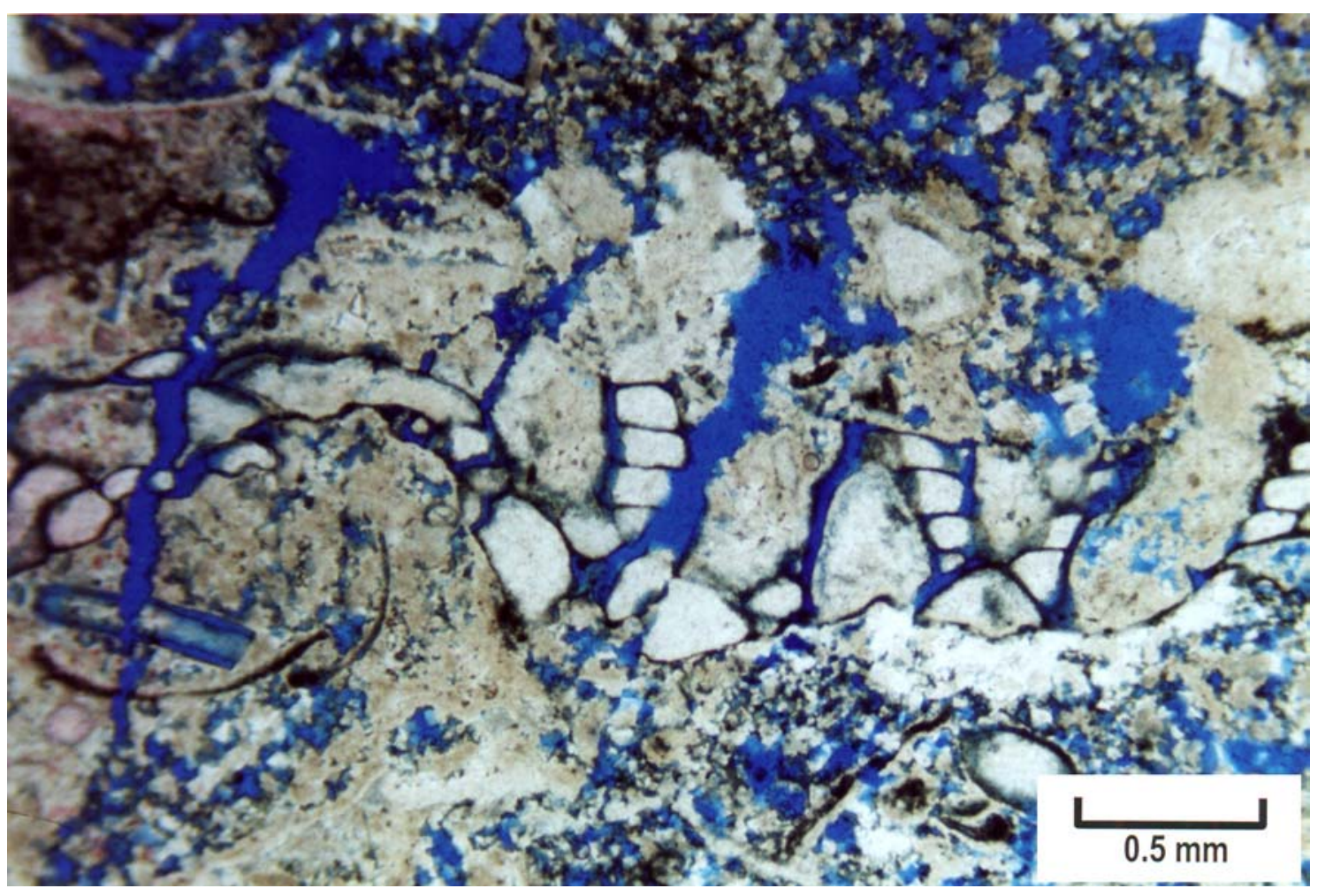




\section{$\underline{5,857.4} \mathbf{f t}$.}

Plug:

Description:

Diagenetic events:

Pore Types: $\varnothing-7.2 \%, \mathrm{~K}-1.6 \mathrm{md}$

skeletal dolomite, wackestone, crinoids, solution, enlarged microfractures, late dissolution microporosity and channel pores, had high porosity but was reduced by much anhydrite plugging and replacement, minor bitumen.

1) early mixing zone dolomitization, 2) late dissolution, and 3) late anhydrite plugging

Mo, micro-BC, $\mathrm{CH}$, micro-FR

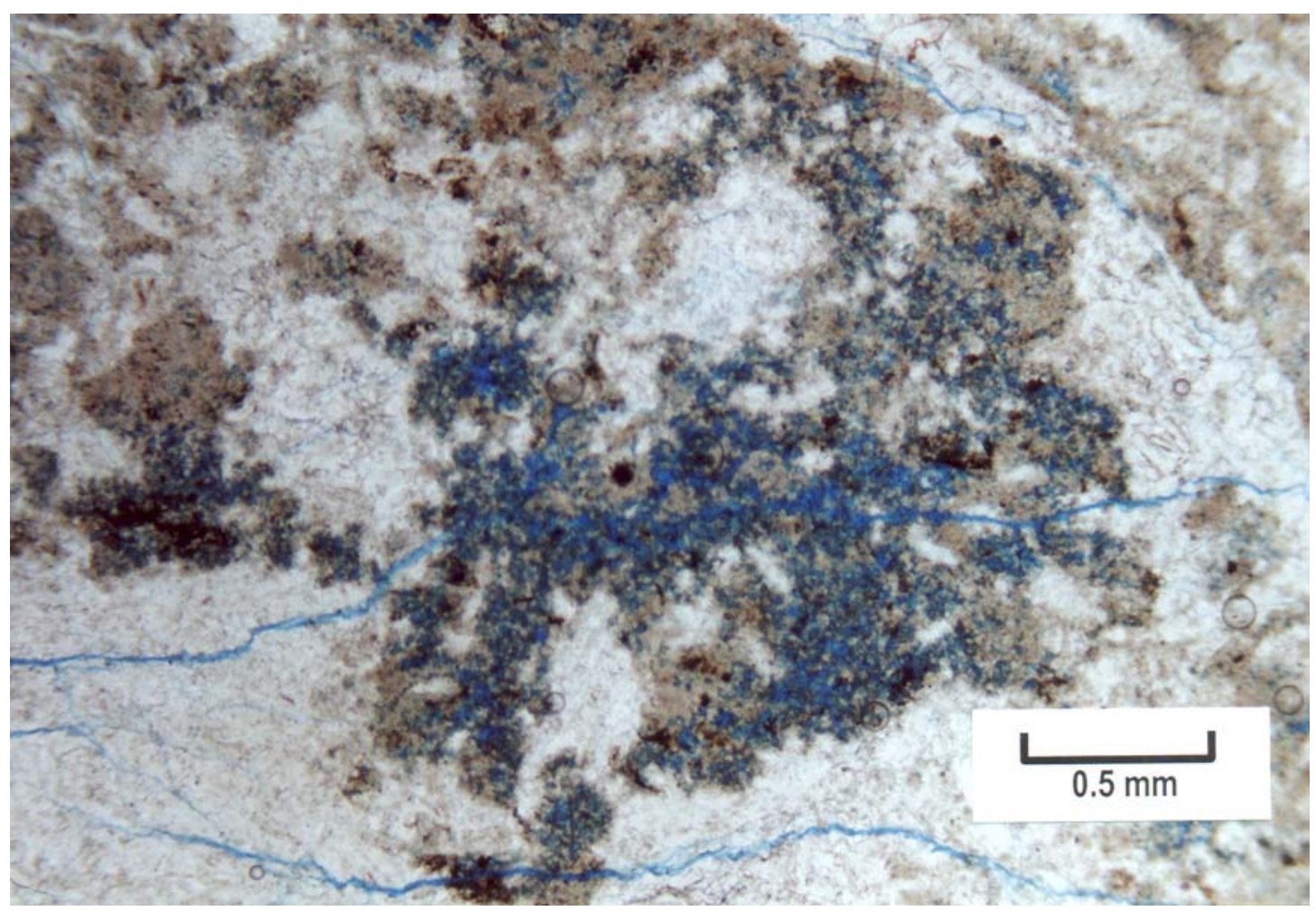




\section{$\underline{5,864.1} \mathbf{f t}$.}
Plug:
$\varnothing-11.2 \%, \mathrm{~K}-0.1 \mathrm{md}$
Description:
dolomite with quartz silt and sponge spicules, late dissolution and formation of microporosity following wispy seams of stylolites.
Diagenetic events: 1) early mixing zone dolomitization, 2) late dissolution to form microporosity, 3) stylolitization
Pore Types: micro-BC

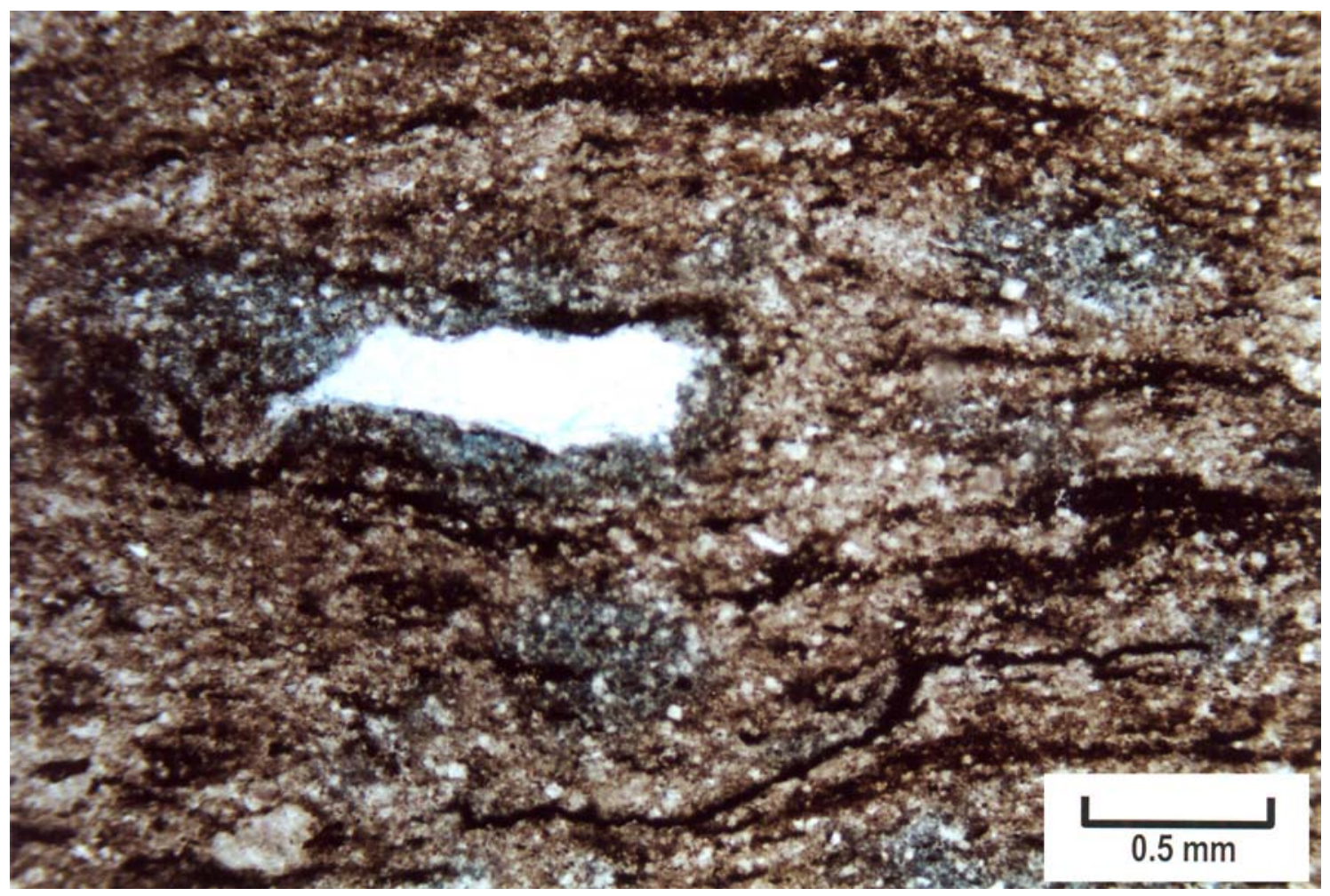




\section{$\underline{5,870.3 \mathrm{ft}}$.}
Plug:
$\varnothing-4.4 \%, \mathrm{~K}-0.02 \mathrm{md}$
Description:
crinoidal wackestone, late-burial diagenesis.
Diagenetic events:
1) late calcite spar, 2) ferroan dolomite within crinoids, 3) non- ferroan saddle dolomite, 4) silicification (chert).
Pore Types: Mo?

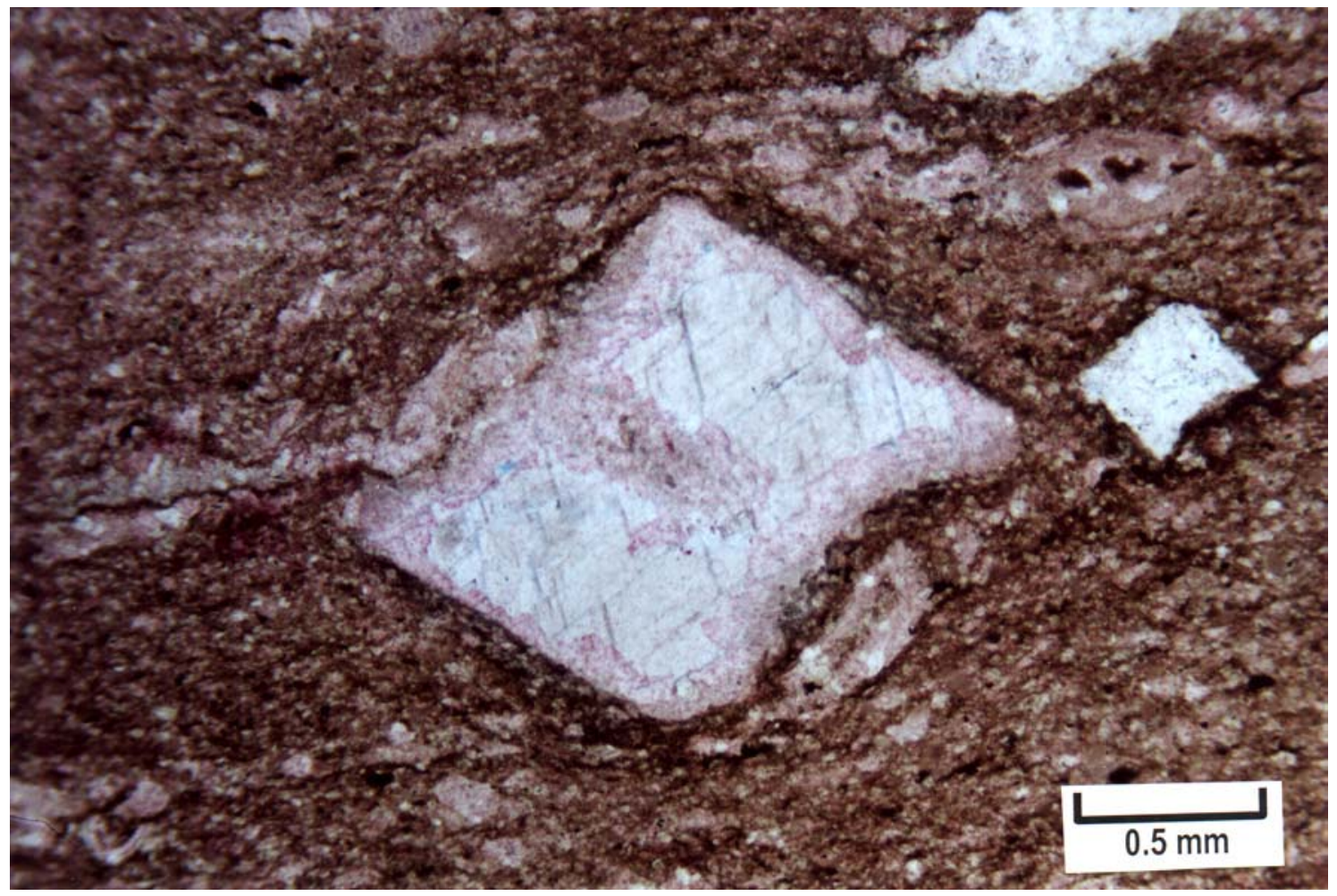




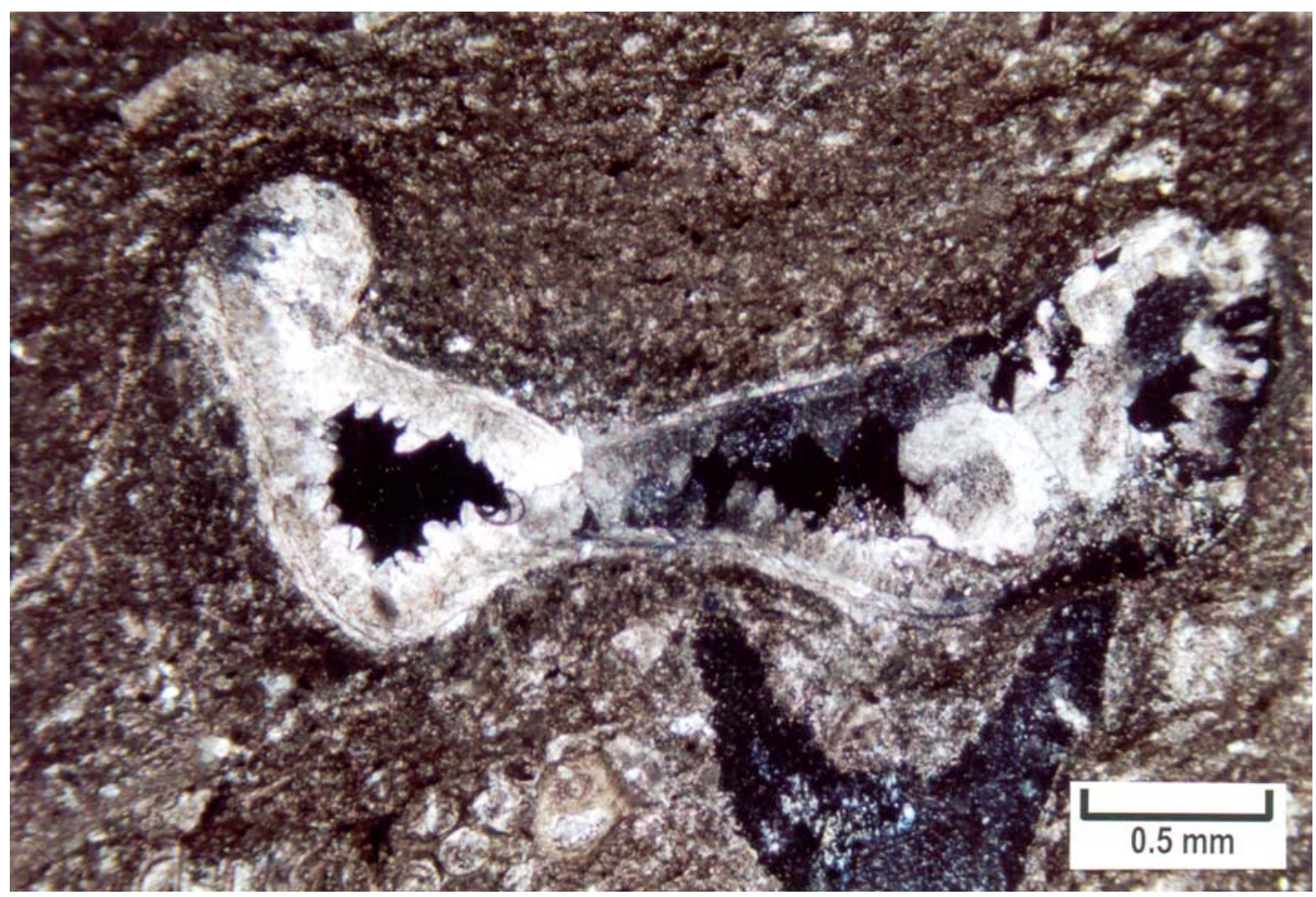




\section{CHEROKEE 33-14, CHEROKEE FIELD}




\section{$\underline{5,773.9} \mathbf{f t}$.}

Plug:

Description:

Diagenetic events:

Pore Types: $\varnothing-19.1 \%, \mathrm{~K}-11 \mathrm{md}$

dolomite; packstone to wackestone, pseudo-brecciation and pseudoclasts (islands of matrix), intense dissolution with solution enlargement of molds to create channels, some anhydrite replacement (10\%), and bitumen.

1) early dolomitization, 2) dissolution/moldic porosity development, 3) extensive microporosity development, 4) anhydrite replacement, 5) bitumen in micropores

$\mathrm{Mo}, \mathrm{CH}$, micro-BC

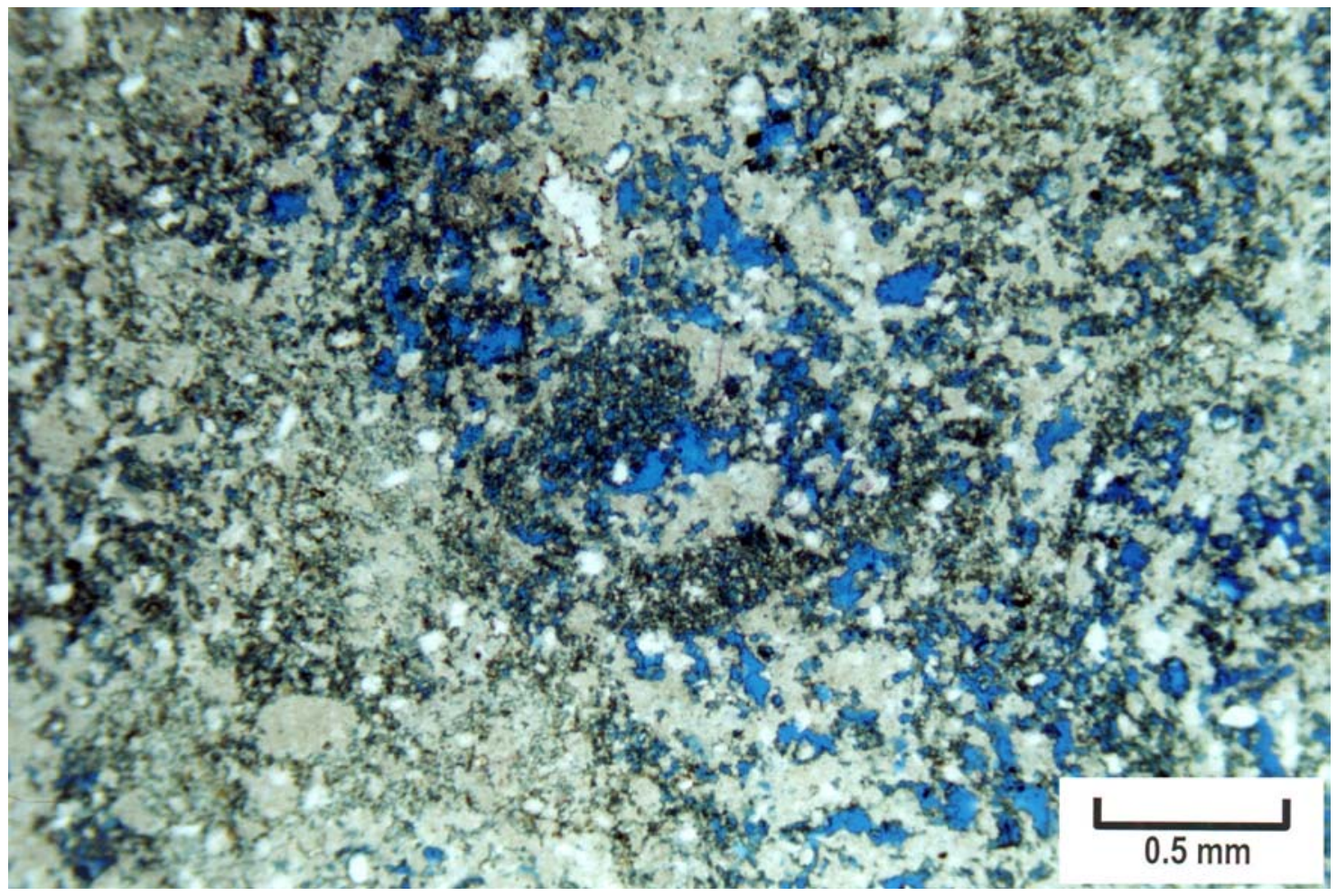




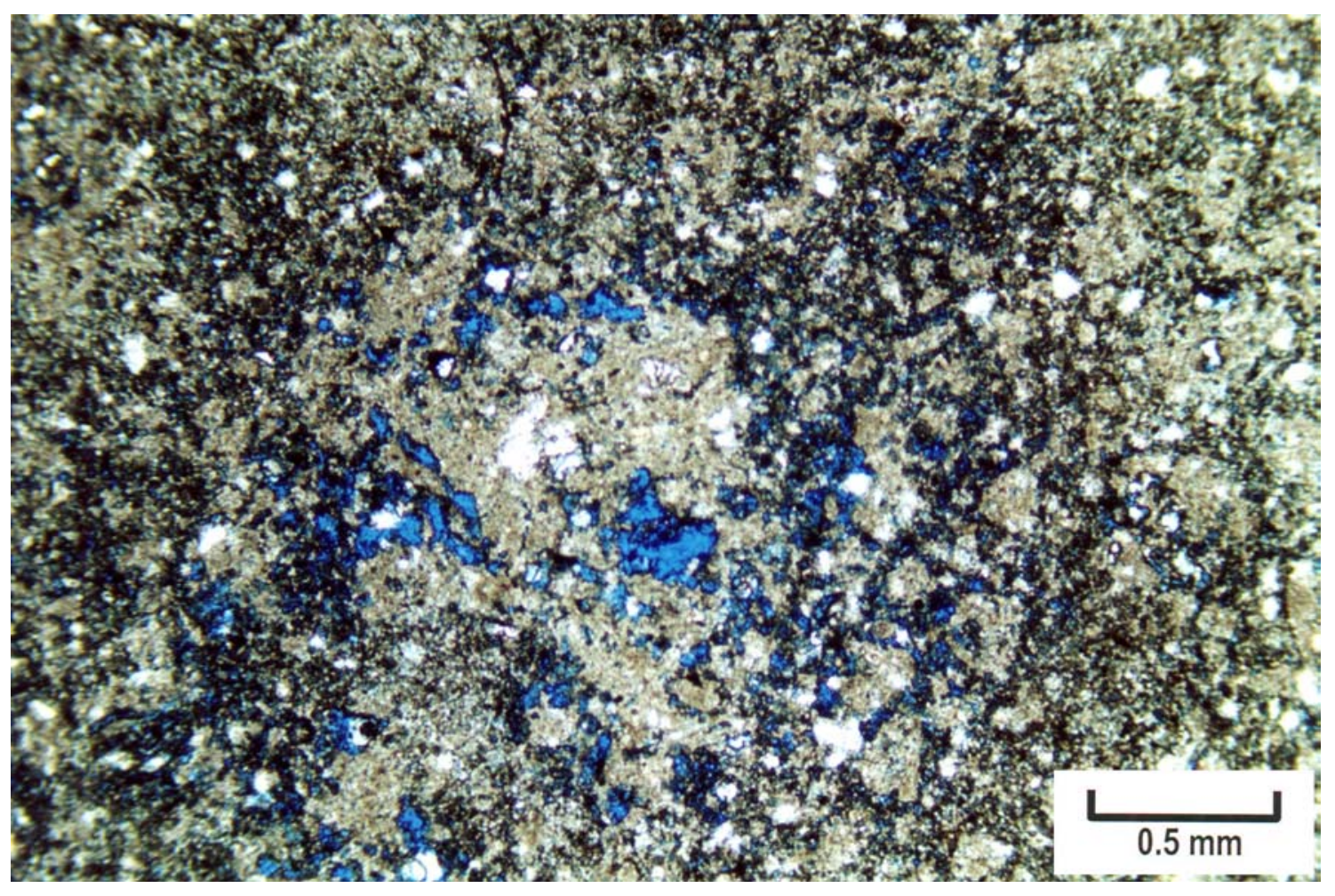




\section{$\underline{5,777.5} \mathbf{f t}$.}

Plug:

Description:

Diagenetic events:

Pore Types: $\varnothing-21.9 \%, \mathrm{~K}-37 \mathrm{md}$

dolomite; packstone to wackestone, patchy pseudo-brecciation with a swirly solution front, heavily modified by dissolution creating late molds, vugs, channels, and microporosity, patchy anhydrite replacement, and a great amount of bitumen.

1) early dolomitization, 2) dissolution/moldic porosity development, 3) extensive microporosity development, 4) anhydrite replacement, 5) bitumen.

$\mathrm{Mo}, \mathrm{CH}$, vugs, micro-BC

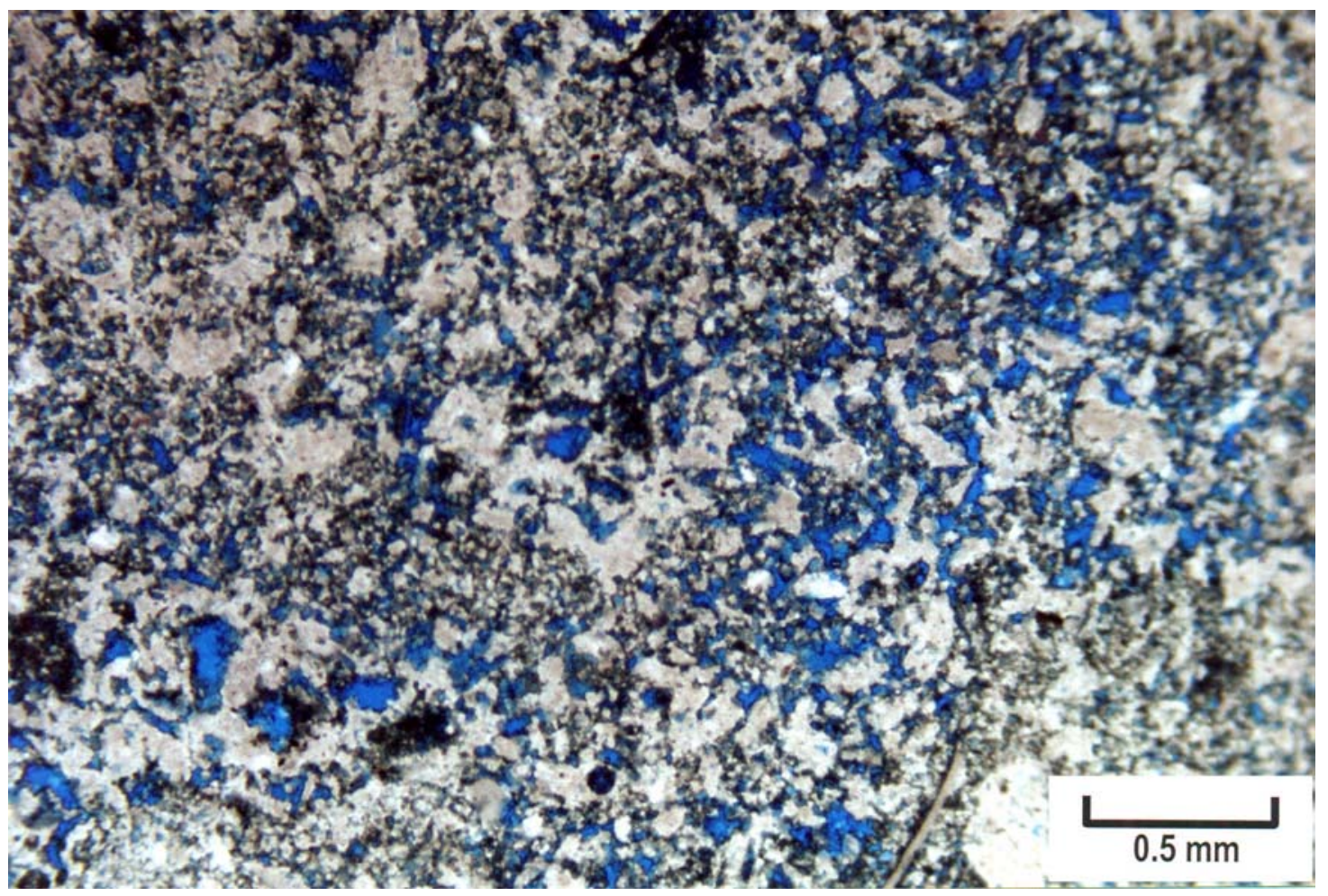



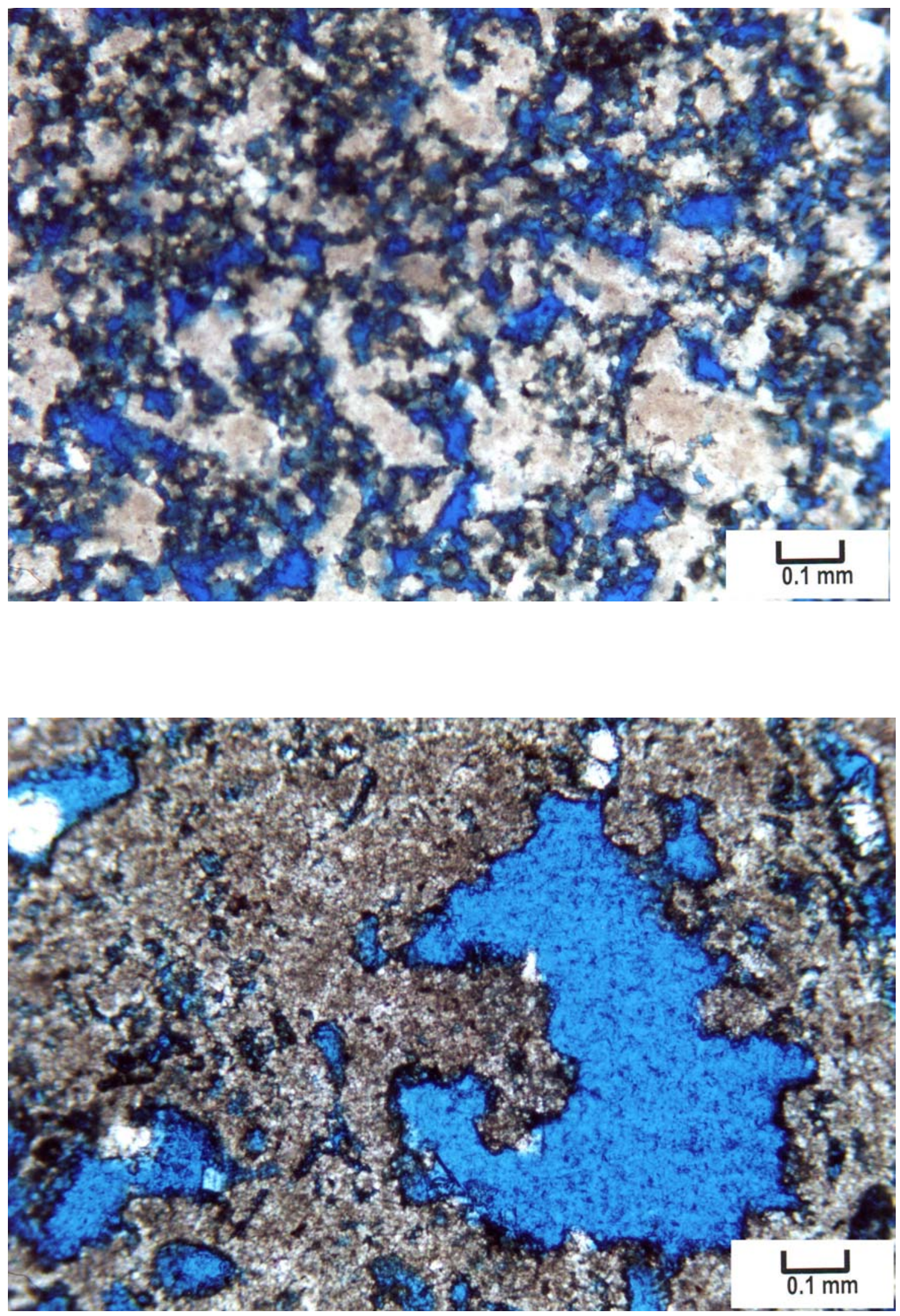


\section{$\underline{5,781.2} \mathbf{f t}$.}

Plug:

Description:

Diagenetic events:

Pore Types: $\varnothing-23.6 \%, \mathrm{~K}-103 \mathrm{md}$

micritic dolomite; mudstone to wackestone, completely altered by late-stage dissolution, some late anhydrite replacement, and a great amount of bitumen.

1) early dolomitization, 2) dissolution/moldic porosity development, 3) extensive dissolution and microporosity development, 4) anhydrite replacement, 5) bitumen.

micro-BC

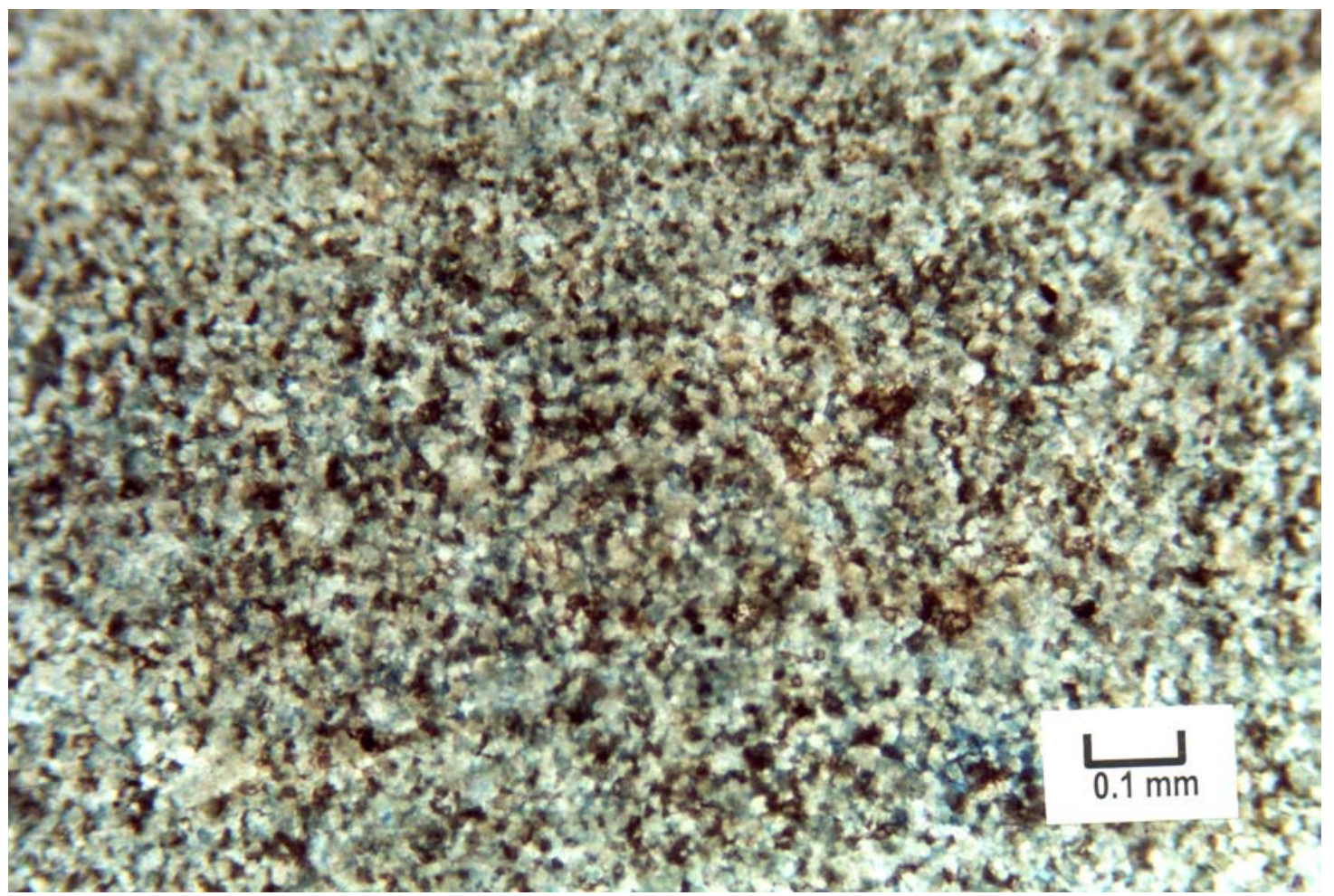




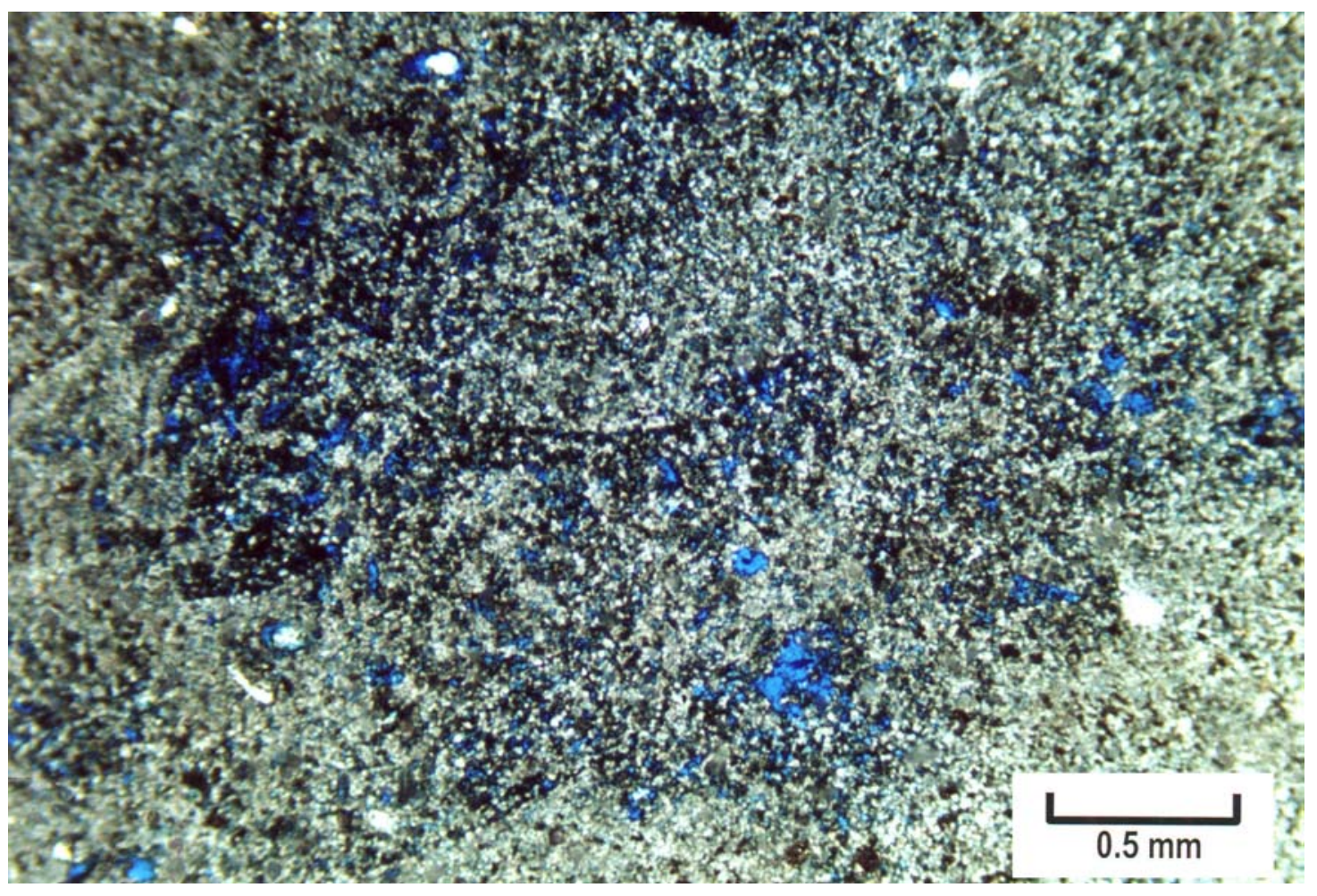




\section{$\underline{5,782.2} \mathbf{f t}$.}

Plug:

Description:

Diagenetic events:

Pore Types: $\varnothing-17.4 \%, \mathrm{~K}-18 \mathrm{md}$

dolomite; wackestone to packstone, pseudo-brecciation, completely altered by late-stage dissolution, solution-enlarged fractures and channels in dense dolomite, some late anhydrite replacement, and a great amount of bitumen.

1) early dolomitization, 2) dissolution/moldic porosity development, 3) extensive dissolution and microporosity development, 4) anhydrite replacement, 5) bitumen.

$\mathrm{FR}, \mathrm{CH}$, micro-BC

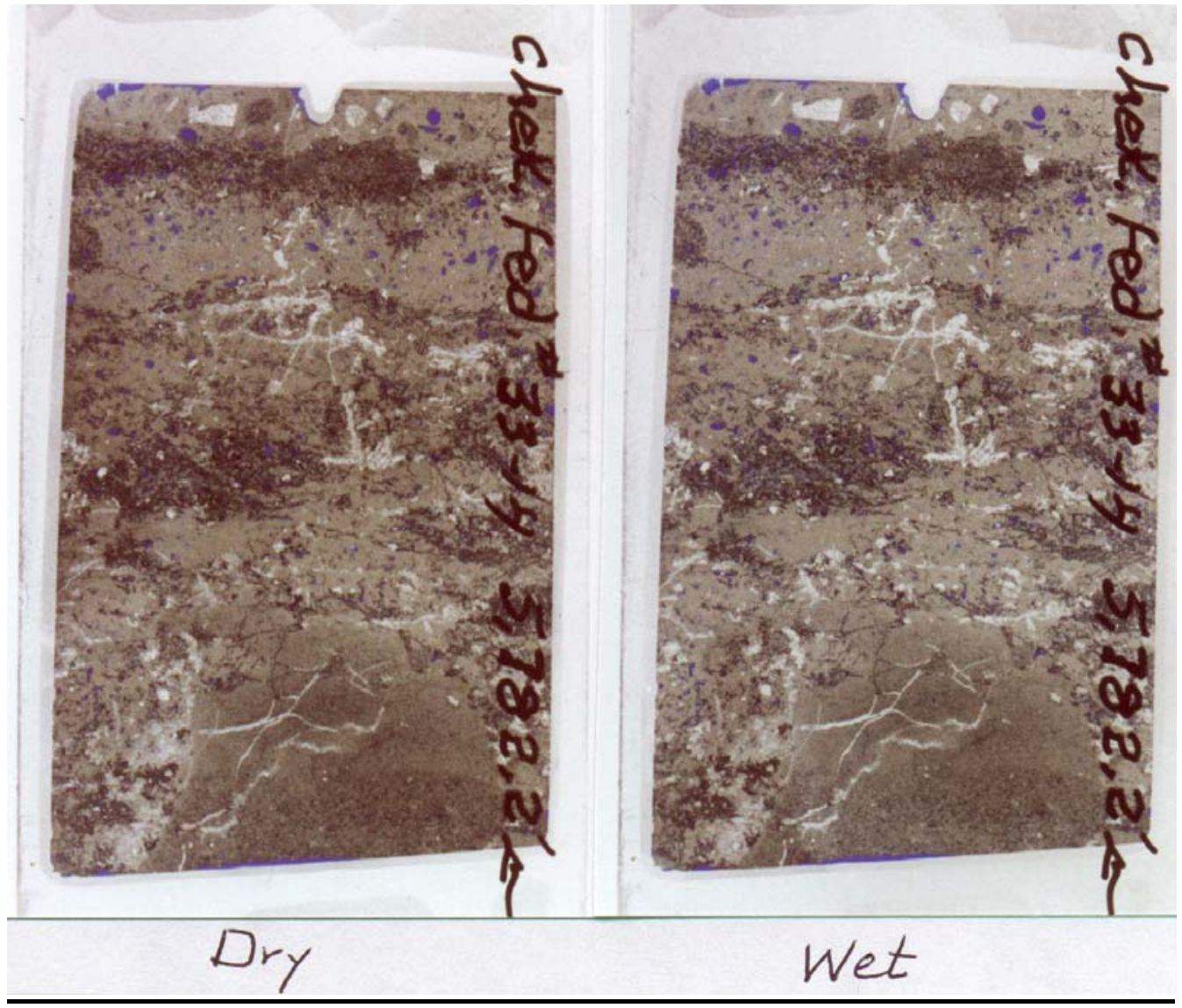




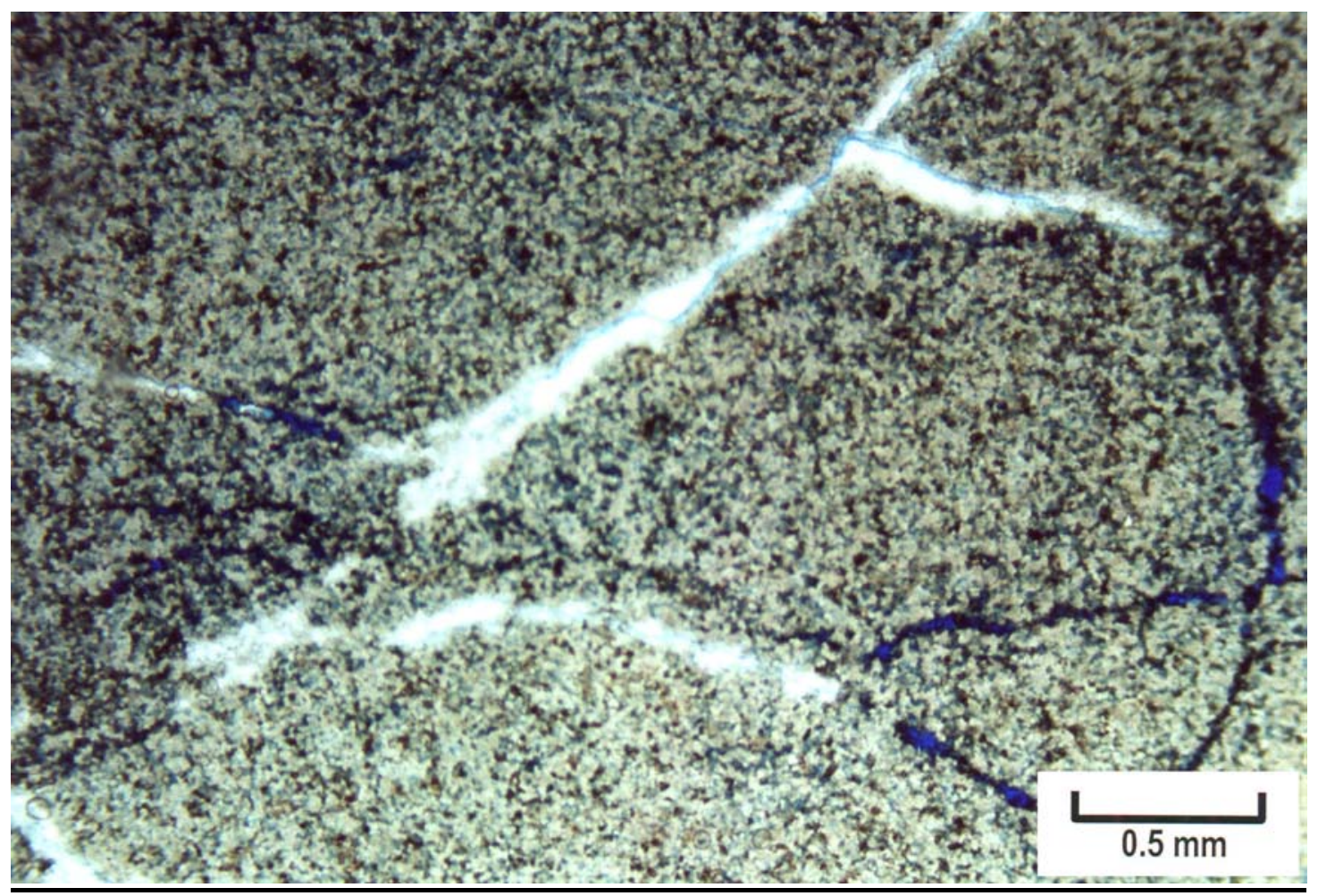




\section{$\underline{5,797.3} \mathbf{f t}$.}

Plug:

Description:

Diagenetic events:

Pore Types: $\varnothing-1.5 \%, \mathrm{~K}-0.22 \mathrm{md}$

dolomite; grainstone, ooids, peloidal, encrusting forams, algal plates, stylolites, some early marine micritic cement on algal plates, late-stage solution front yielding channel pores and microporosity, late anhydrite plugging and healed fractures, and bitumen.

1) early-marine micritic cements, 2) early dolomitization 3) extensive dissolution and microporosity development, 4) anhydrite replacement, 5) bitumen.

a few $\mathrm{CH}$, micro-BC

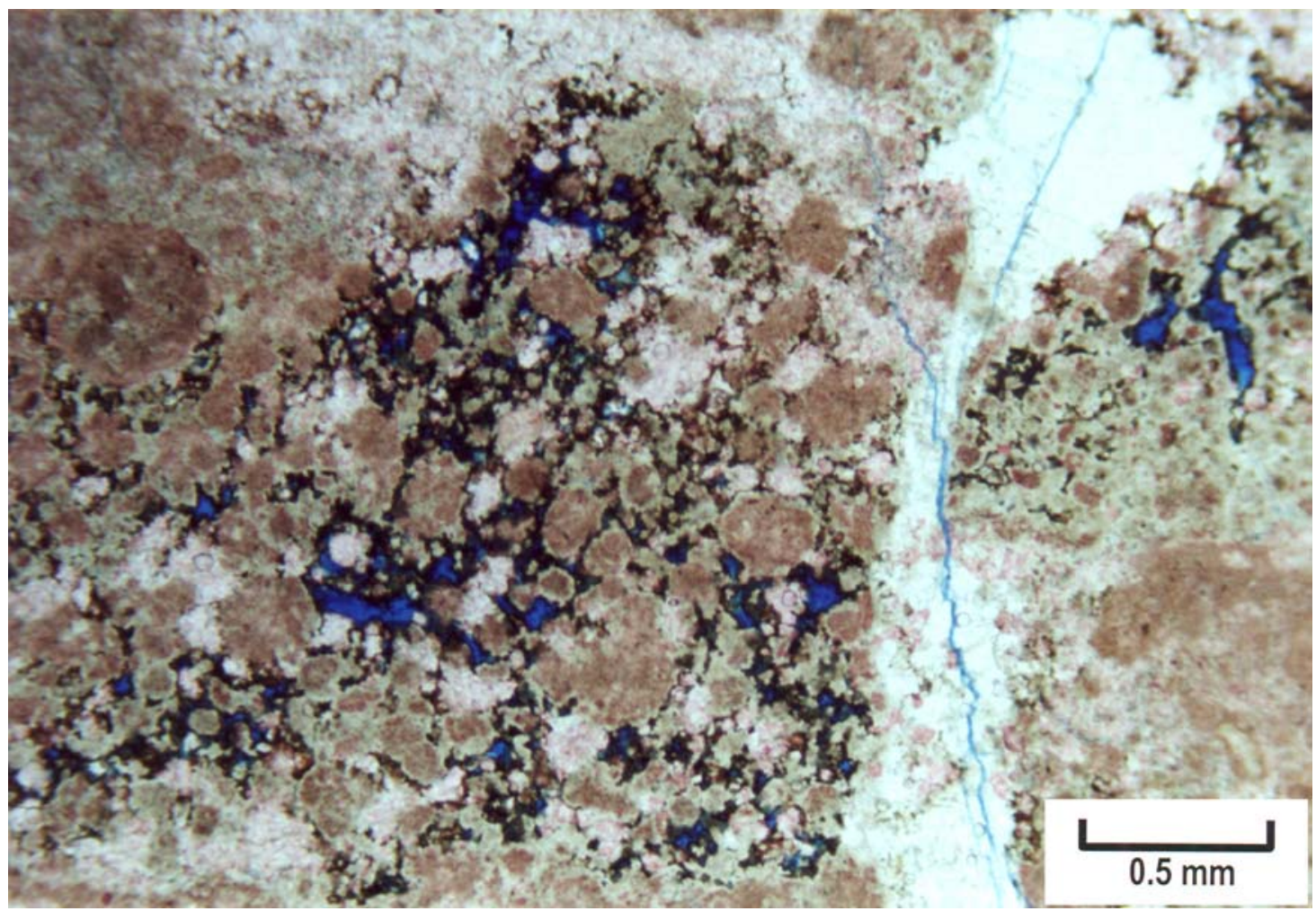




\section{MAY BUG 2, BUG FIELD}




\section{$\underline{6,304.0} \mathbf{f t}$.}

Plug:

Description:

Diagenetic events:

Pore Types: $\varnothing-10.9 \%, \mathrm{~K}-99 \mathrm{md}$

dolomite; phylloid-algal bafflestone, in place phylloid algal plates, shelter pores with internal sediments, grading into cement (micrite rims that mark the outlines of a former phylloid plates), dogtooth spar on solution-enlarged fractures, micro-box-work/hollow dolomites present due to freshwater (forming as precipitates in freshwater or leached dolomite after formation in freshwater), poorly preserved leached botryoidal fans of early marine cement (aragonite); no anhydrite or bitumen.

1) early marine cementation (botryoidal cement) 2) meteoric leaching of phylloid plates, 3) leaching to vugs, 4) early dolomitization (mixing zone or seepage reflux).

$\mathrm{SH}$, vug, BC, Mo, FR

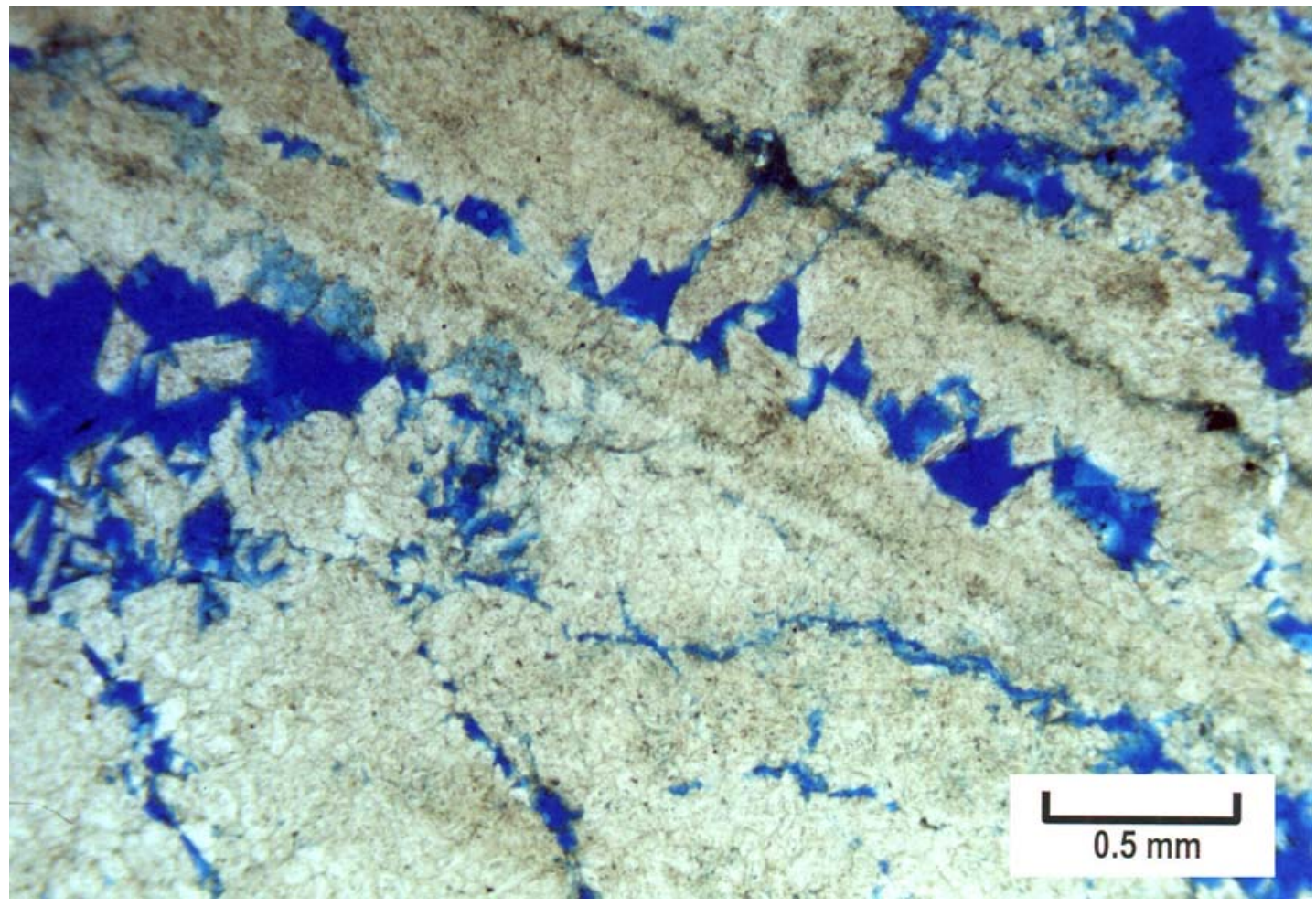



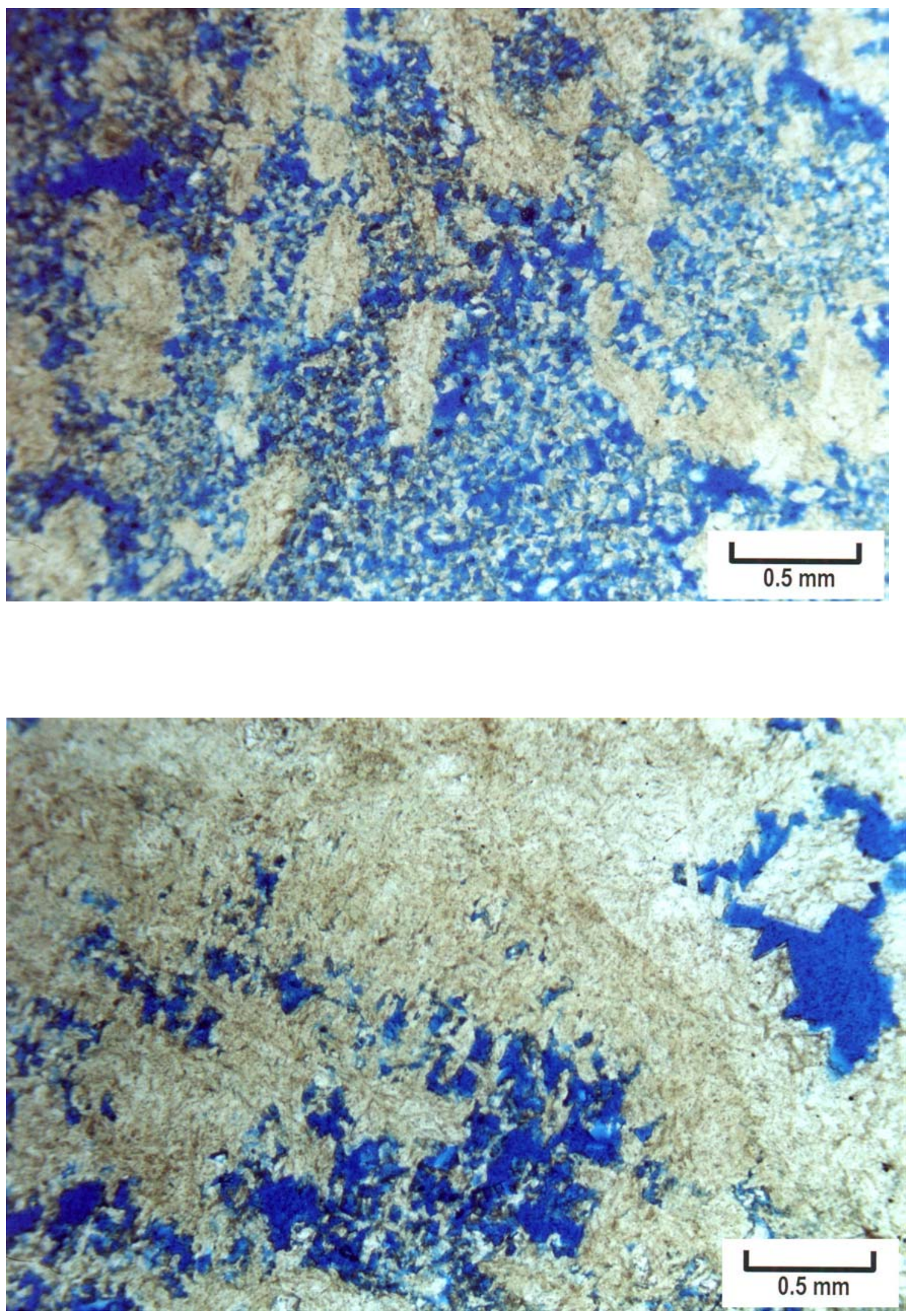


\section{$\underline{6,306.0} \mathrm{ft}$.}

Plug:

Description:

Diagenetic events:

Pore Types: $\varnothing-10.6 \%, \mathrm{~K}-60 \mathrm{md}$

dolomite; phylloid-algal bafflestone, blunt-ended botryoidal fans, outlined with sediment, of early marine cement (aragonite) partially leached; post-dolomitization extensive leaching (meteoric dissolution) resulting in channel pores and linear solution-enlarged fractures.

1) early marine cementation (botryoidal cement) 2) meteoric leaching of phylloid plates, 3) leaching to vugs, 4) early dolomitization (mixing zone or seepage reflux).

$\mathrm{SH}$, vug, BC, Mo, FR

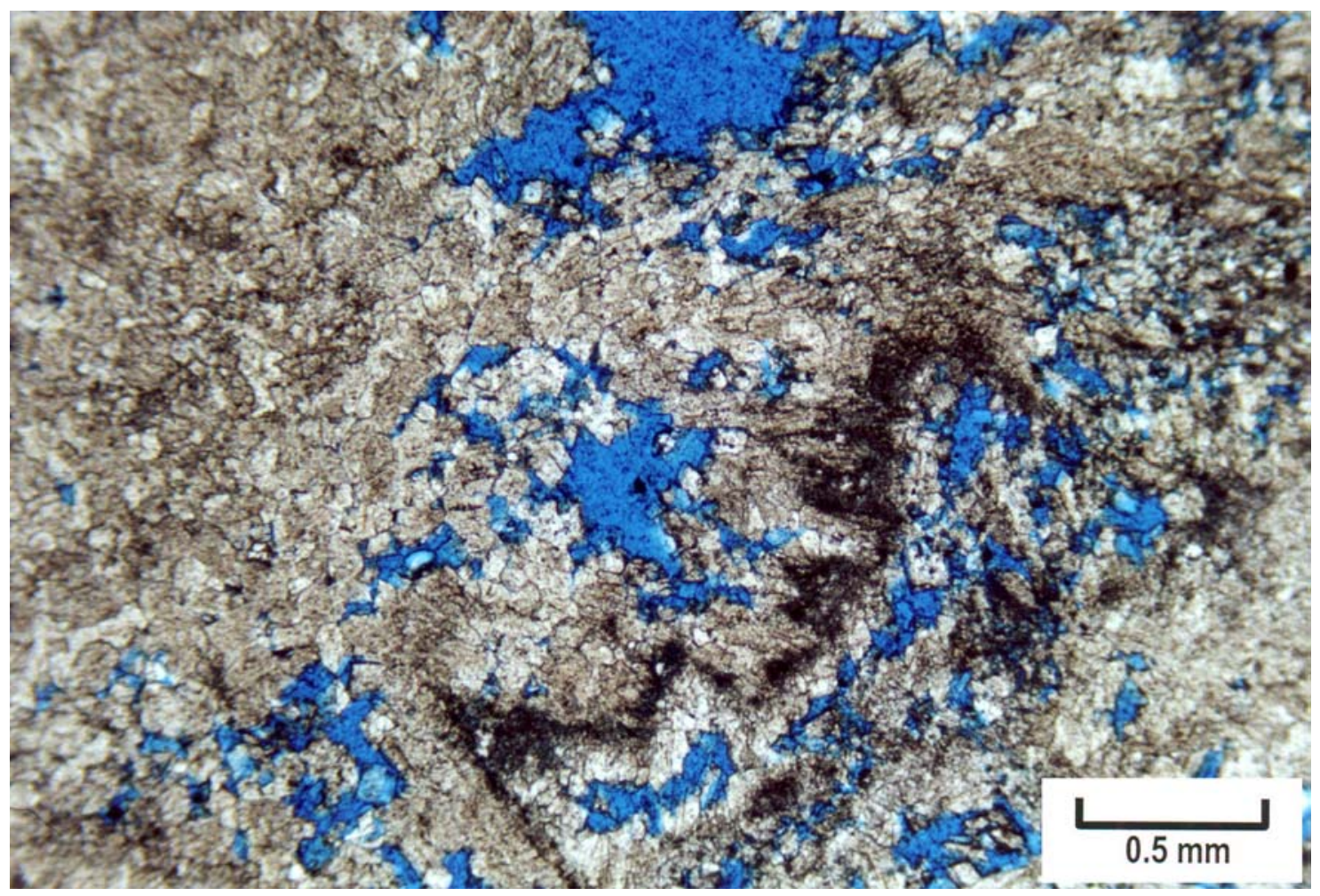




\section{$\underline{6,312.0 \mathrm{ft}}$.}

Plug:

Description:

Diagenetic events:

Pore Types: $\varnothing-14.9 \%, \mathrm{~K}-30 \mathrm{md}$

dolomite; phylloid-algal bafflestone, compaction breakage of phylloid algal plates, some shelter pores with internal sediments; meteoric leaching; solution-enlarged fractures, bedding planes, and micro-caves; micro-box-work/hollow dolomites; late anhydrite going to cement (chert).

1) early marine cementation (botryoidal cement) 2) meteoric leaching of phylloid plates, 3) leaching to vugs, 4) early dolomitization (mixing zone or seepage reflux), 5) anhydrite replacement, and 6) silicification.

$\mathrm{SH}$, vug, BC, Mo, FR

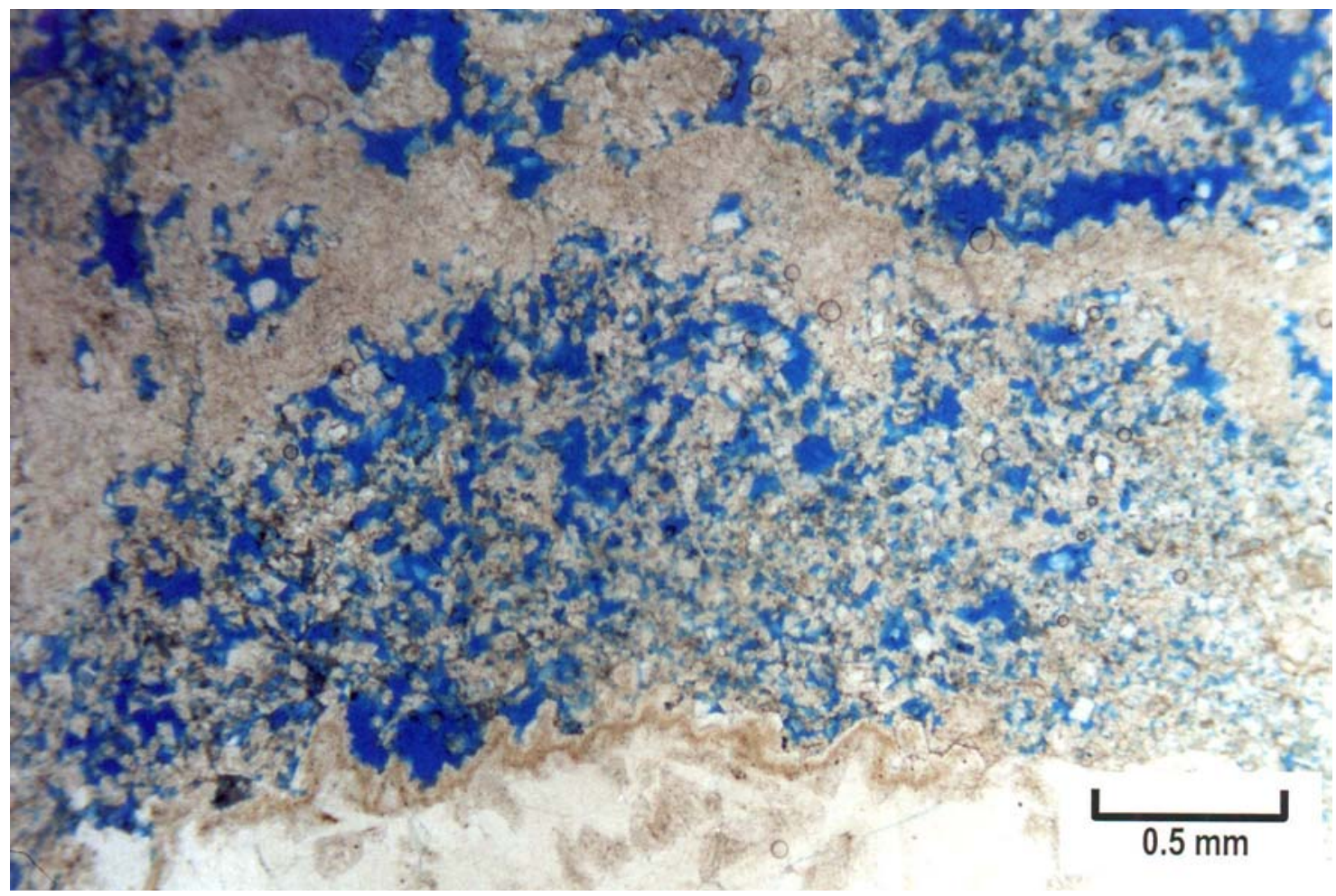




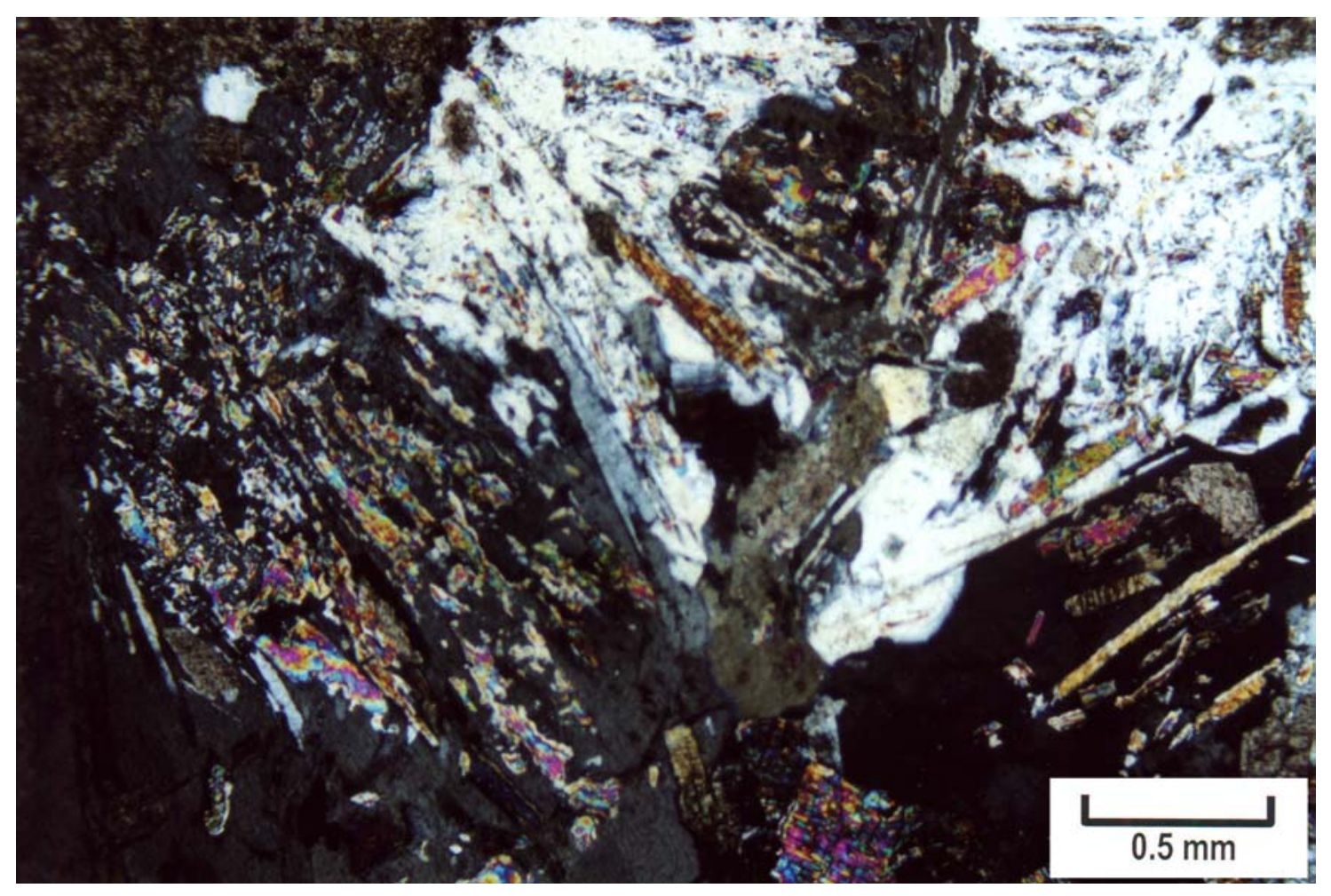




\section{$\underline{6,313.5} \mathrm{ft}$.}

Plug:

Description:

Diagenetic events:

Pore Types: $\varnothing-13.4 \%, \mathrm{~K}-20 \mathrm{md}$

dolomite; phylloid-algal bafflestone (still in mound); early depositional layer, skeletal, crystal growth of anhydrite as an early cement - bottom growth of gypsum now anhydrite plus late anhydrite pore filling.

1) dolomitization, 2) meteoric leaching of phylloid plates to form vugs, 3) early anhydritic cement, and 4) late anhydrite cement.

$\mathrm{SH}$, vug, BC, Mo

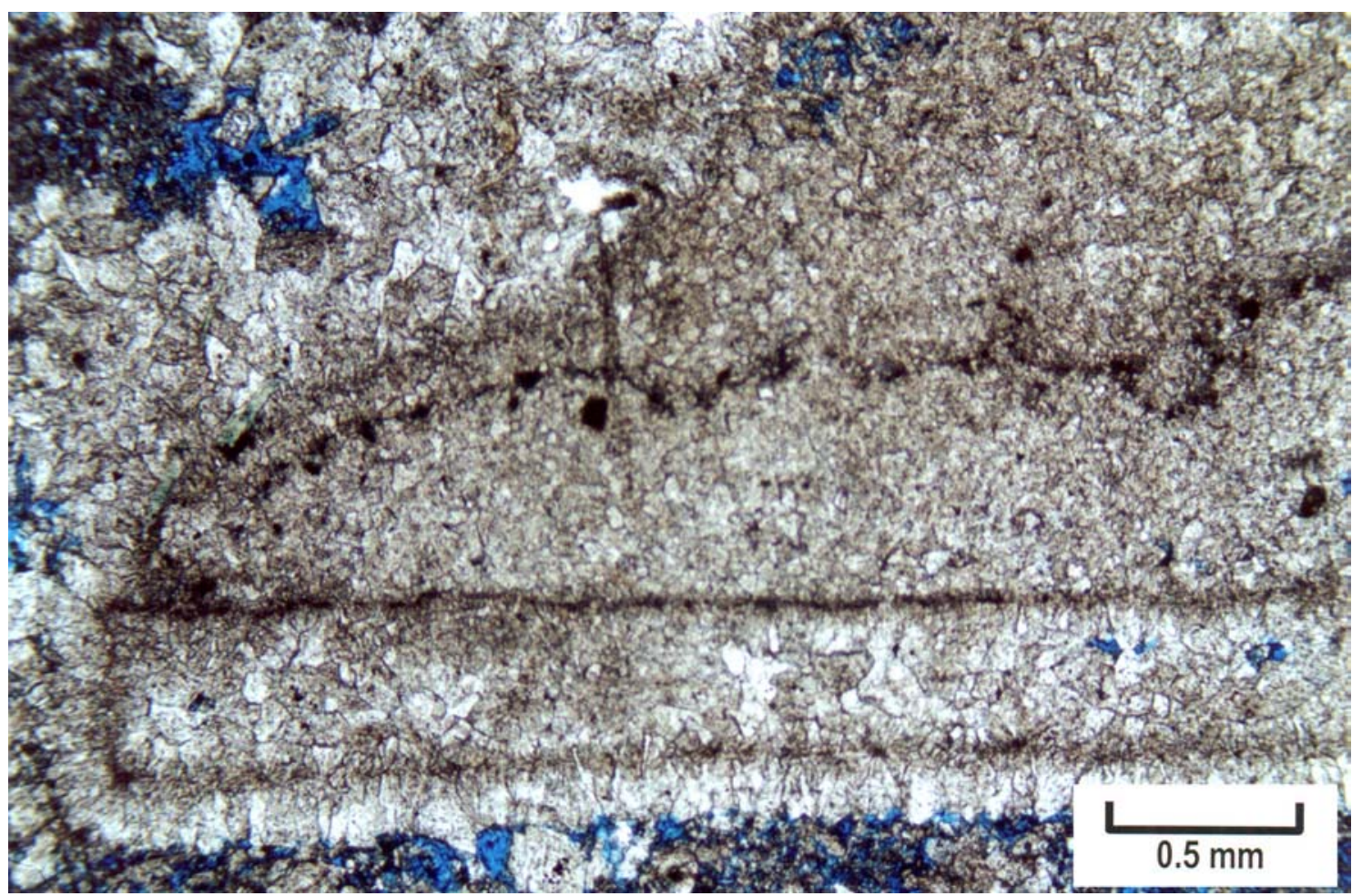




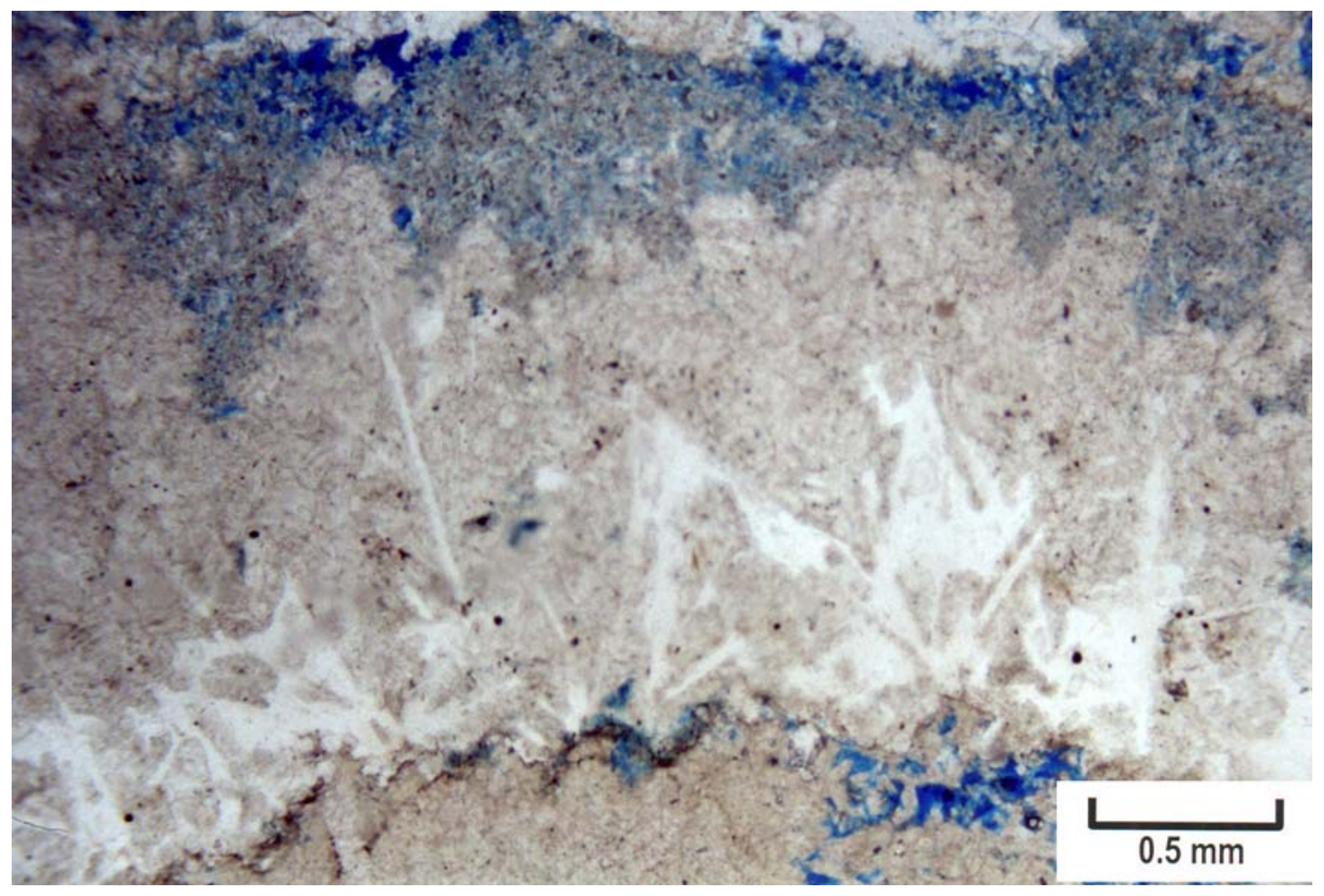




\section{$\underline{6,315} \mathrm{ft}$.}

Plug:

Description:

Diagenetic events:

Pore Types: $\varnothing-10.3 \%, \mathrm{~K}-5.7 \mathrm{md}$

dolomite; phylloid-algal bafflestone; vuggy from solution-enlarged of pores, dissolution/leaching (post dolomitization); remnant cement on phylloid algal plates; micro-box-work/hollow dolomites; sharp transition between dolomitization to micro-boxwork, some late anhydrite and bitumen. EF shows a few patches of tight dolomite with oil and some pores with oil bleeding into them from adjacent tight dolomite; oil accumulates up against anhydrite.

1) dolomitization, 2) meteoric leaching of phylloid plates to form vugs, 3) formation of box-work/hollow dolomite, 4) anhydrite replacement, and 5) bitumen.

$\mathrm{SH}$, vug, BC, Mo, FR

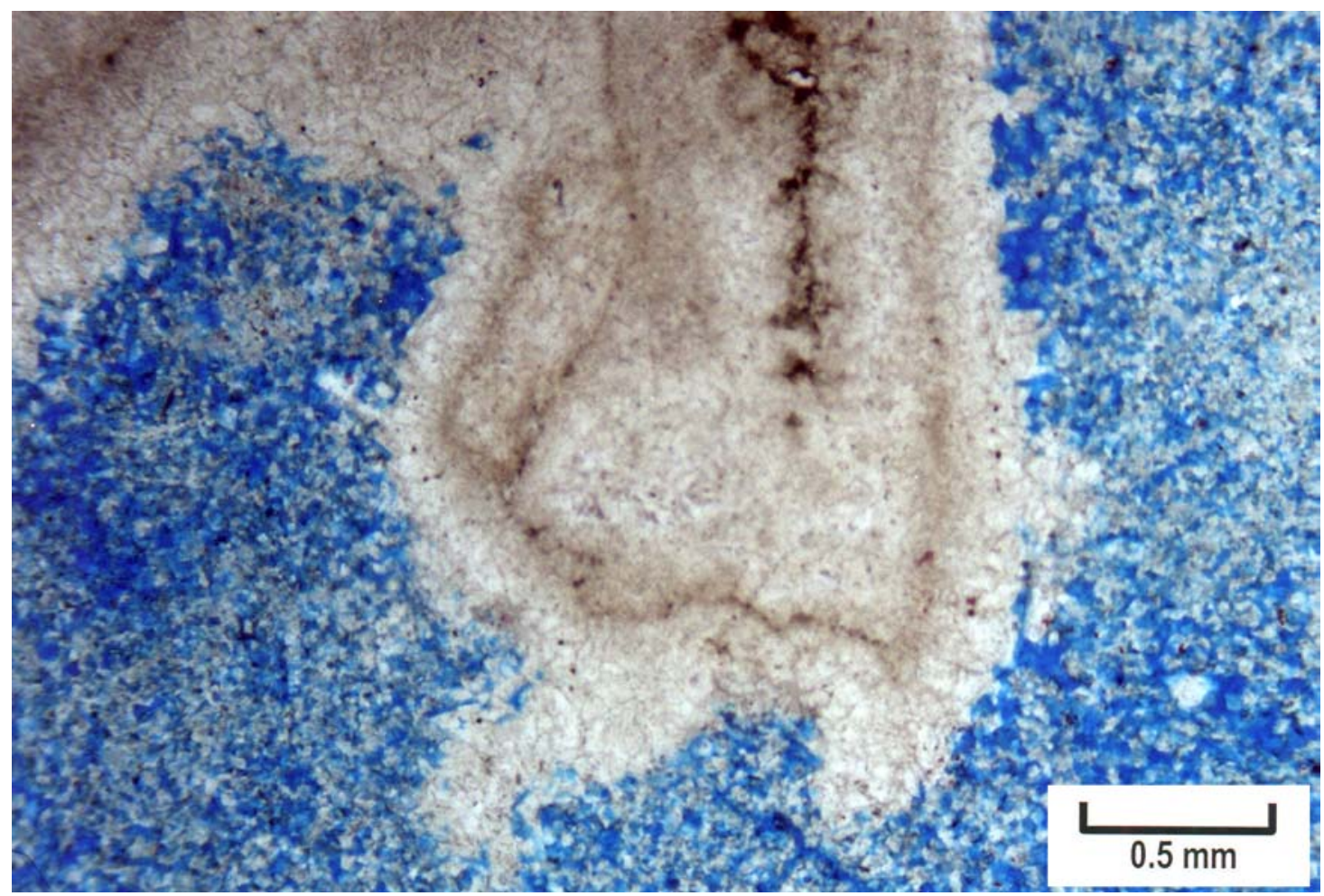




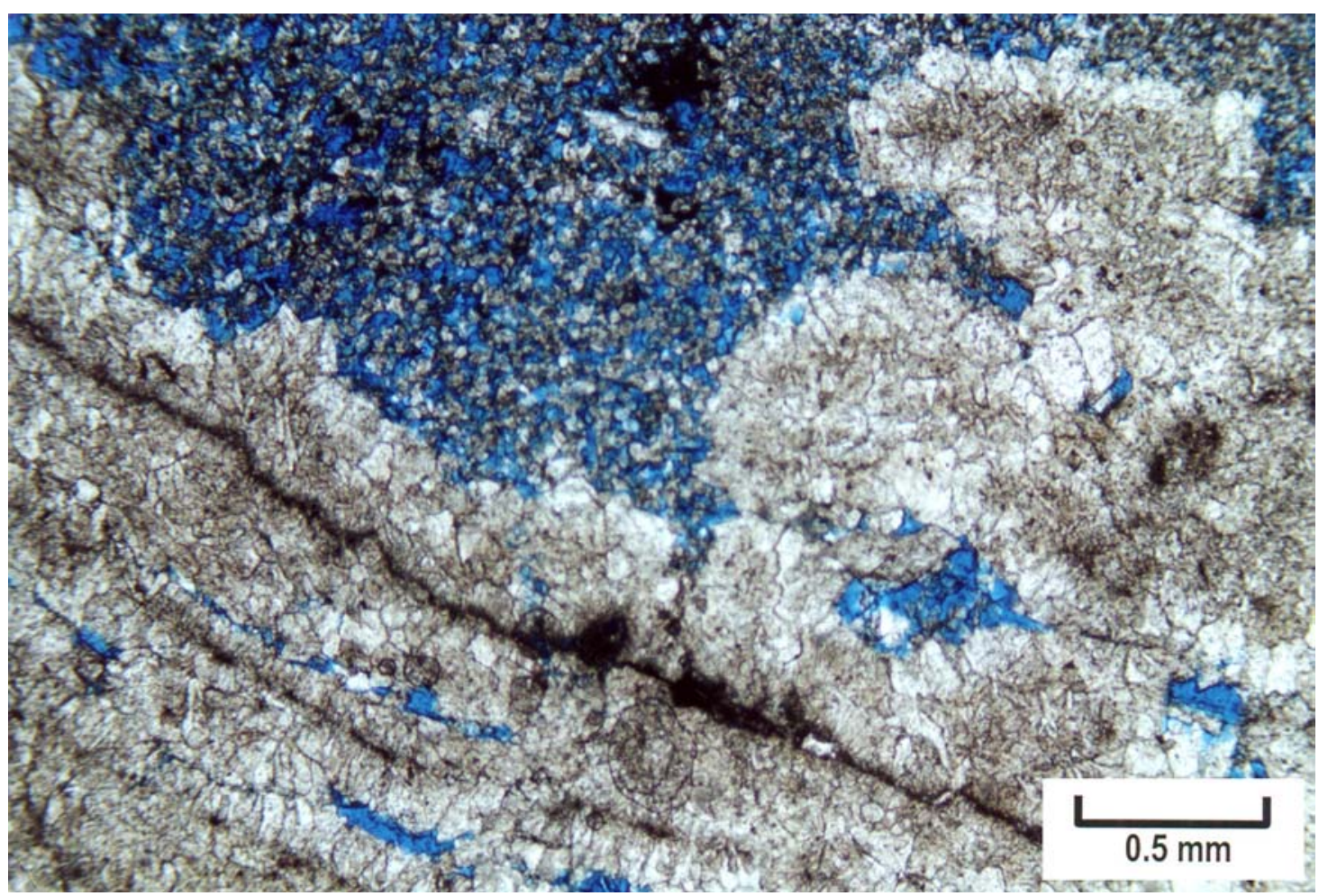




\section{BUG 3, BUG FIELD}




\section{$\underline{6,355.7 \mathrm{ft}}$.}
Plug:
$\varnothing$ - No data (ND), K - ND
Description:
siltstone (no dolomite); quartz silt, mica (muscovite) chert, some
Diagenetic events: grains of calcite silt; and some anhydrite replacement.
Pore Types: anhydrite replacement none

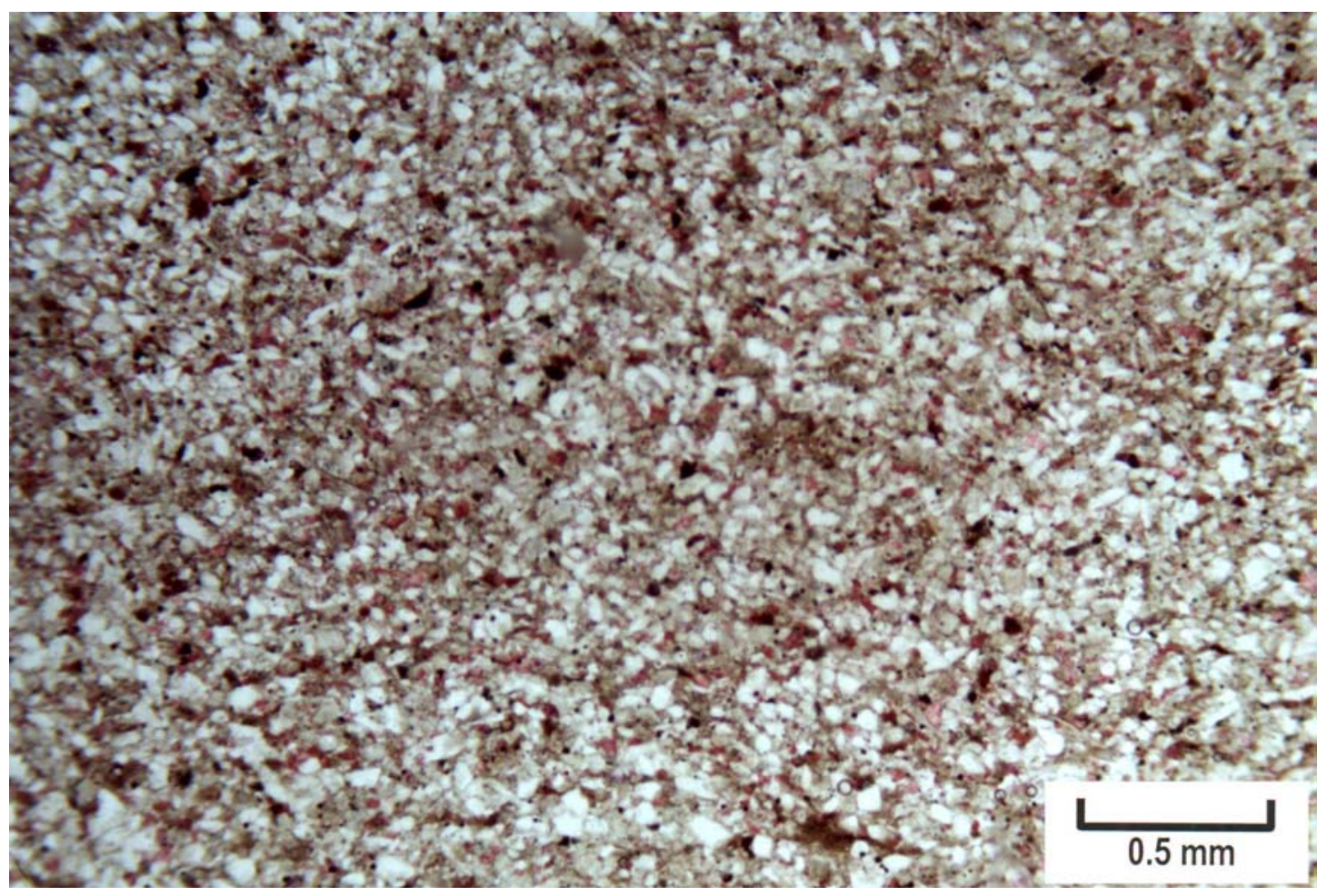



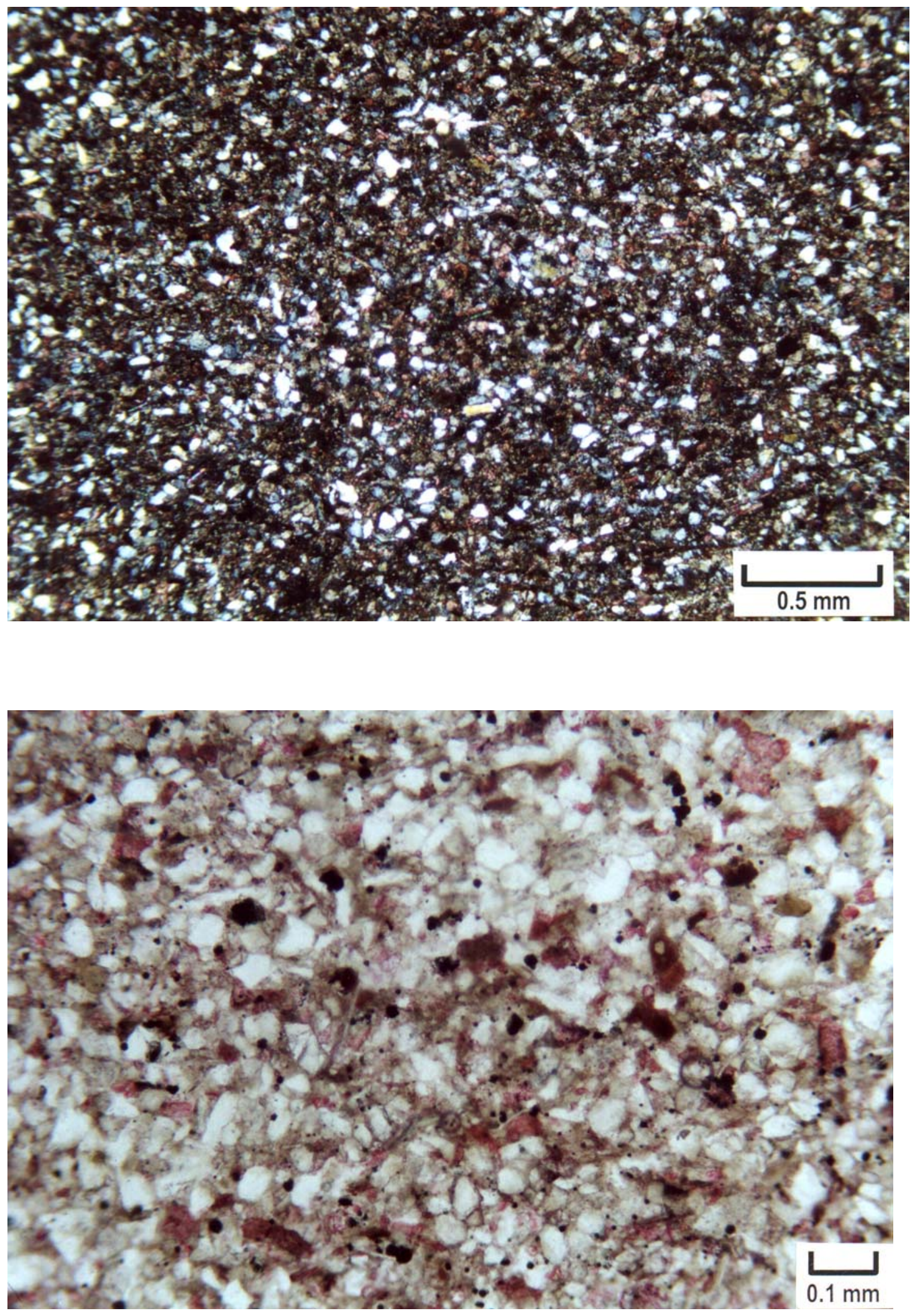


\section{BUG 4, BUG FIELD}




\section{$\underline{6,284.2} \mathrm{ft}$.}

Plug:

Description:

Pore Types: $\varnothing-6.9 \%, \mathrm{~K}-2.5 \mathrm{md}$

skeletal peloidal dolomite; grainstone to packstone; bladed fresh water cement; dissolution; bitumen-lined pores filled with anhydrite.

Diagenetic events: 1) meteoric leaching of leaching to vugs, interparticle porosity, and intraparticle porosity, 2) freshwater cementation, 3) early dolomitization (mixing zone or seepage reflux), 4) bitumen, and 5) anhydrite plugging (?).

WP, BP, vug

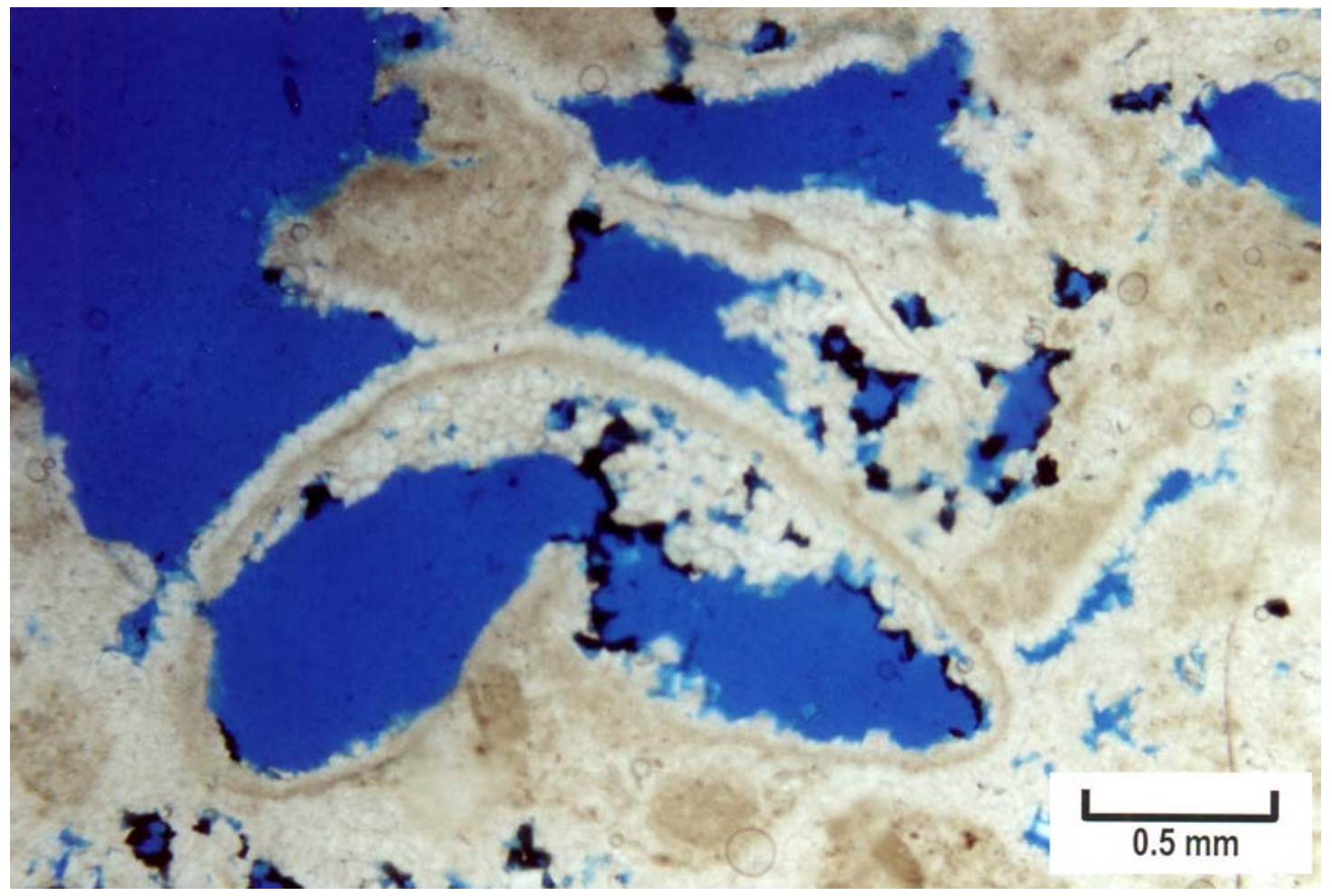




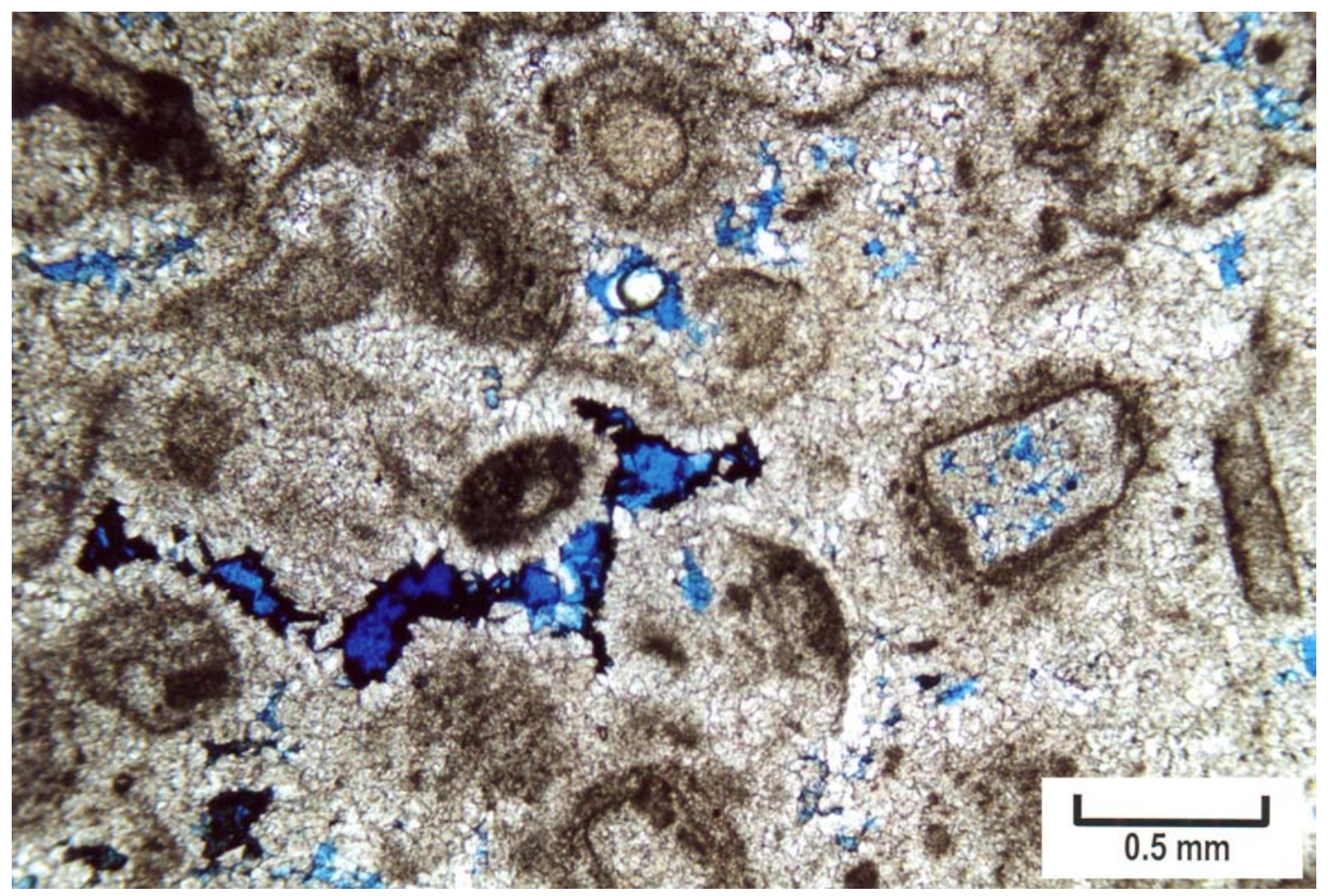




\section{$\underline{6,289.7} \mathrm{ft}$.}

Plug:

Description:

Diagenetic events:

Pore Types: $\varnothing-14.5 \%, \mathrm{~K}-92 \mathrm{md}$

dolomite; phylloid-algal bafflestone; phylloid algal plates with shelter pores; bladed botryoidal early marine cement; dogtooth calcite spar on shelter pores; leaching/dissolution to micro-boxwork/hollow dolomites; bitumen.

1) early marine cementation (botryoidal cement) 2) freshwater cements, 3) meteoric leaching of phylloid plates and leaching to form vugs and micro-box-work dolomite, 4) early dolomitization (mixing zone or seepage reflux), and 5) bitumen.

$\mathrm{SH}$, vug, BC

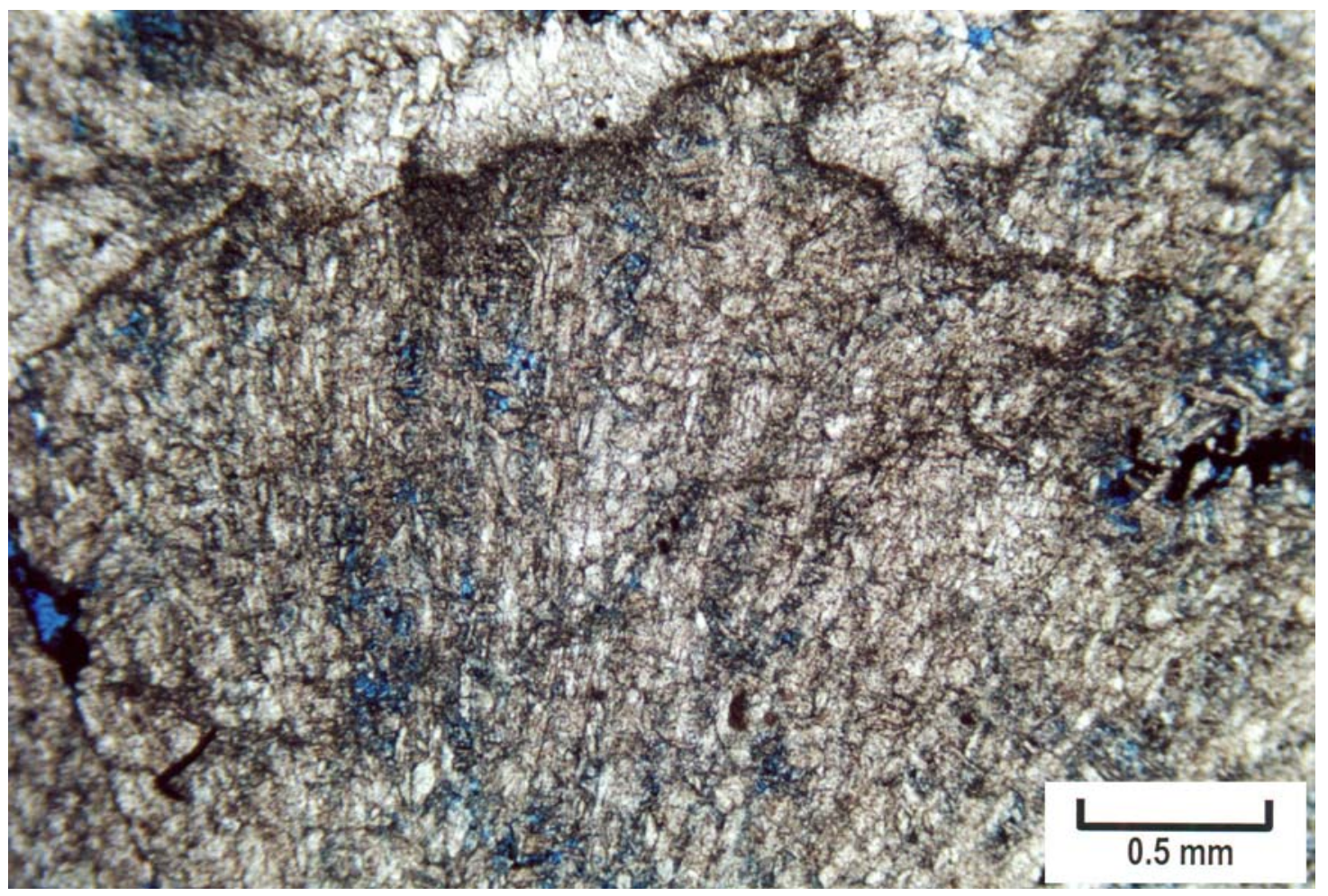



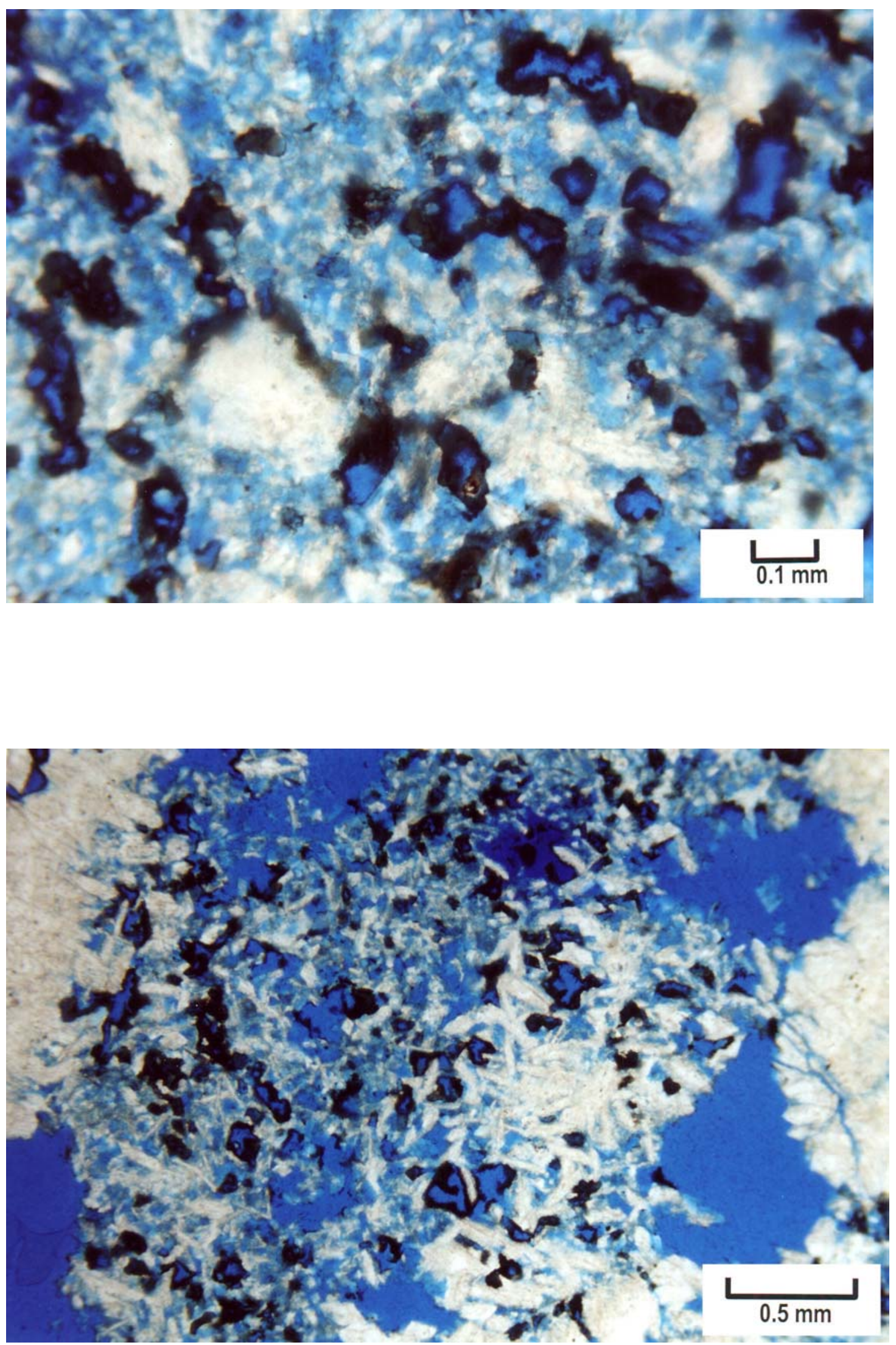


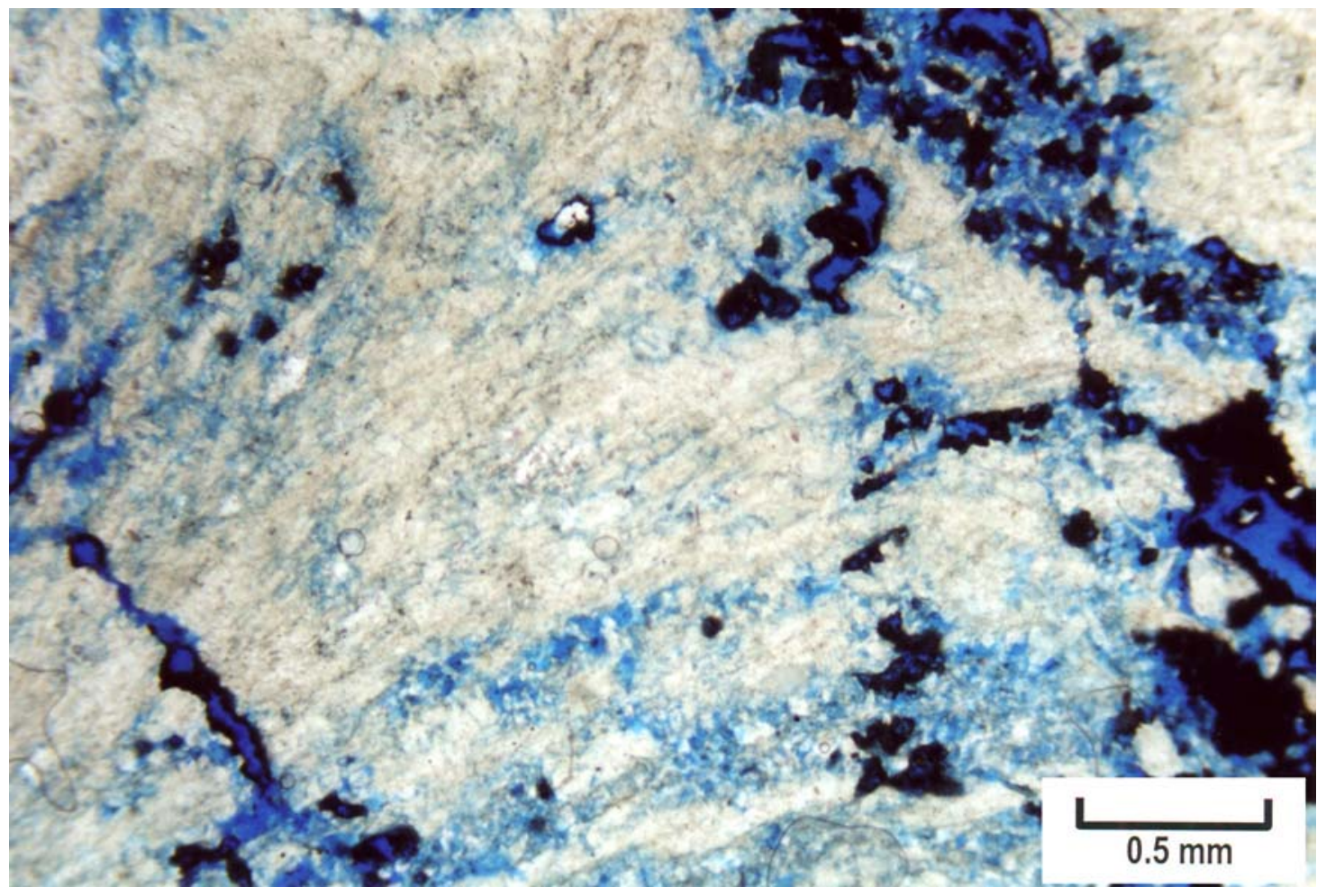




\section{$\underline{6,294.3} \mathrm{ft}$.}

Plug:

Description:

Diagenetic events:

Pore Types: $\varnothing-13.5 \%, \mathrm{~K}-87 \mathrm{md}$

dolomite; phylloid-algal bafflestone; internal sediment; solutionenlarged pores; leaching/dissolution to molds and micro-boxwork/hollow dolomites; late hydrothermal caused microporosity; some bitumen.

1) meteoric leaching of phylloid plates and leaching to form vugs and micro-box-work dolomite, 2) early dolomitization (mixing zone or seepage reflux), 3) late dissolution/microporosity development, and 4) bitumen.

$\mathrm{BC}, \mathrm{Mo}$, micro-BC

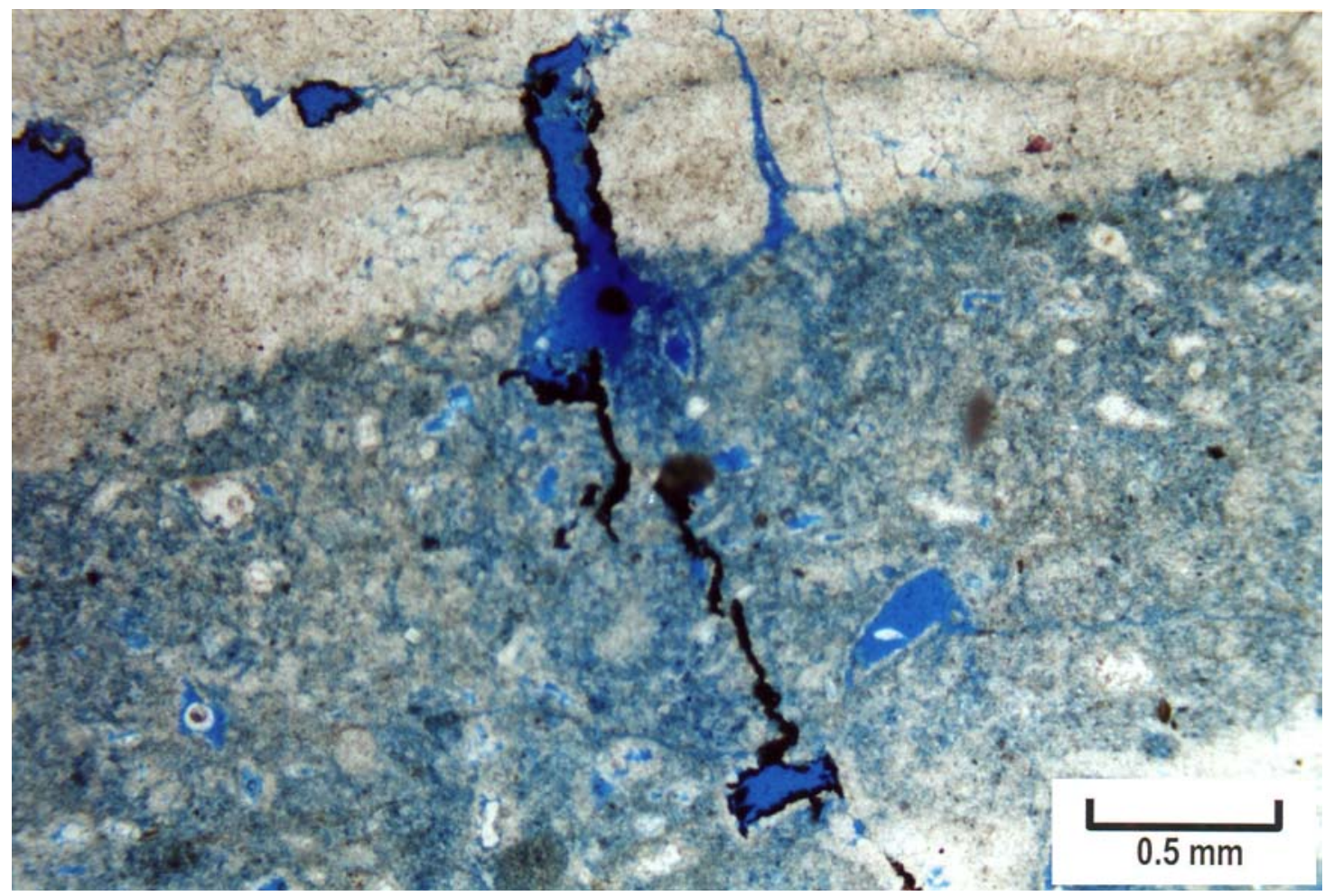



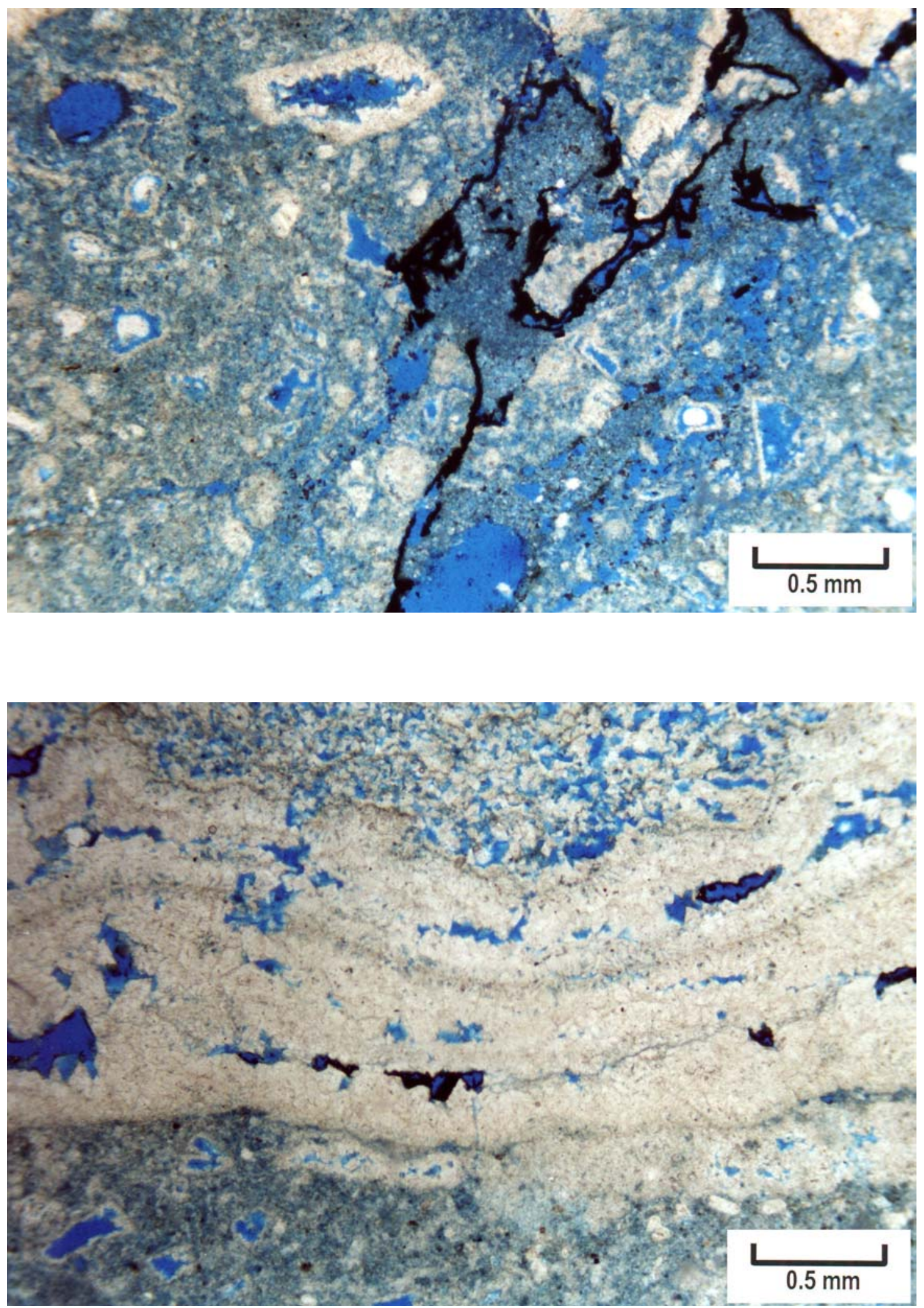

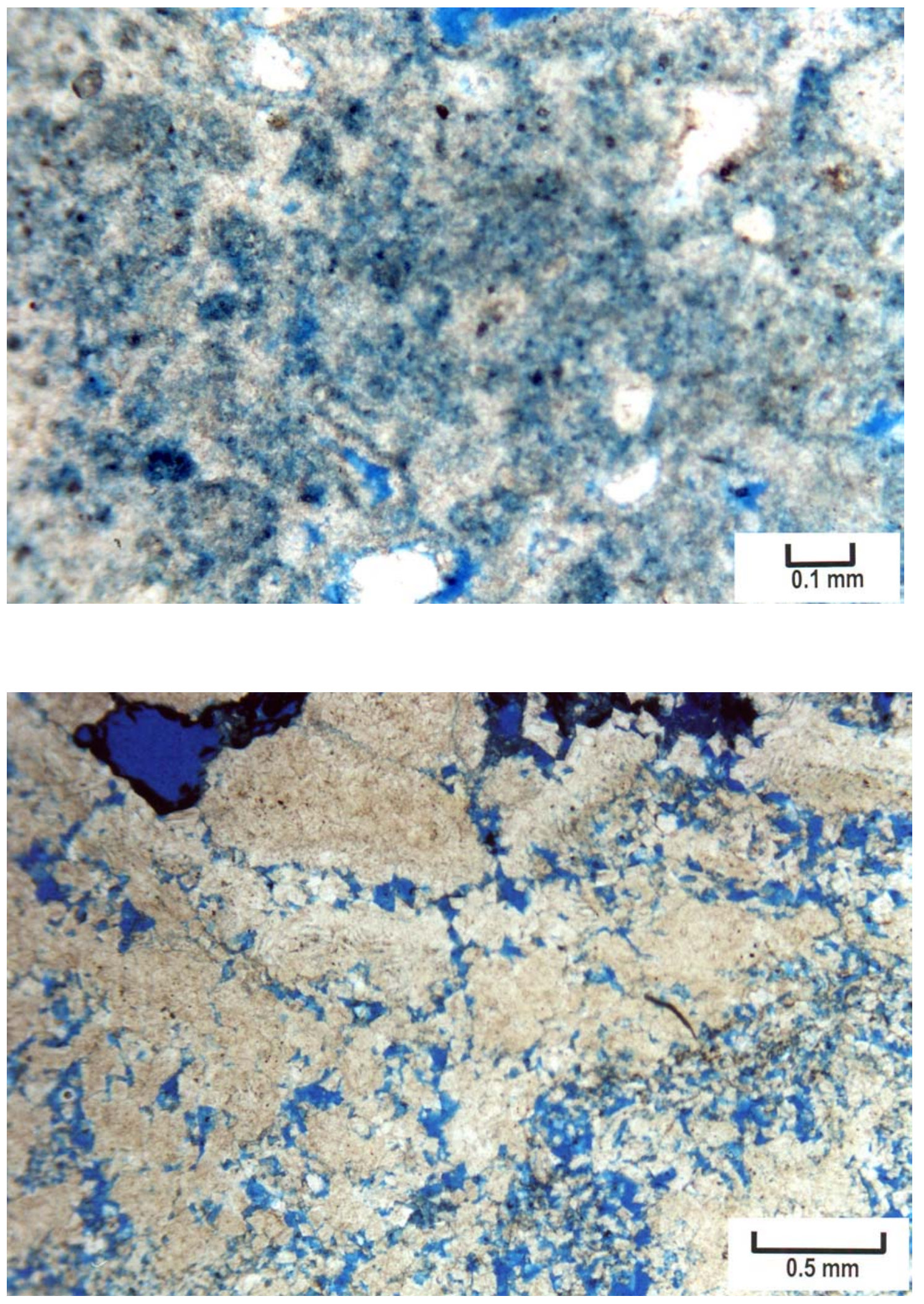


\section{$\underline{6,297.4} \mathbf{f t}$.}

Plug:

Description:

Diagenetic events:

Pore Types: $\varnothing-10.5 \%, \mathrm{~K}-18 \mathrm{md}$

dolomite; phylloid-algal bafflestone; remnant of early marine cement (botryoidal) along vugs; leaching and solution front of micro-box-work/hollow dolomite; some anhydrite; chalcedony (silica).

1) early marine botryoidal cementation, 2) meteoric leaching of phylloid plates to vugs, 3) early dolomitization (mixing zone or seepage reflux), 4) micro-box-work dolomitization, 5) anhydrite replacement, and 6) chalcedony (silica) replacement.

vug, BC

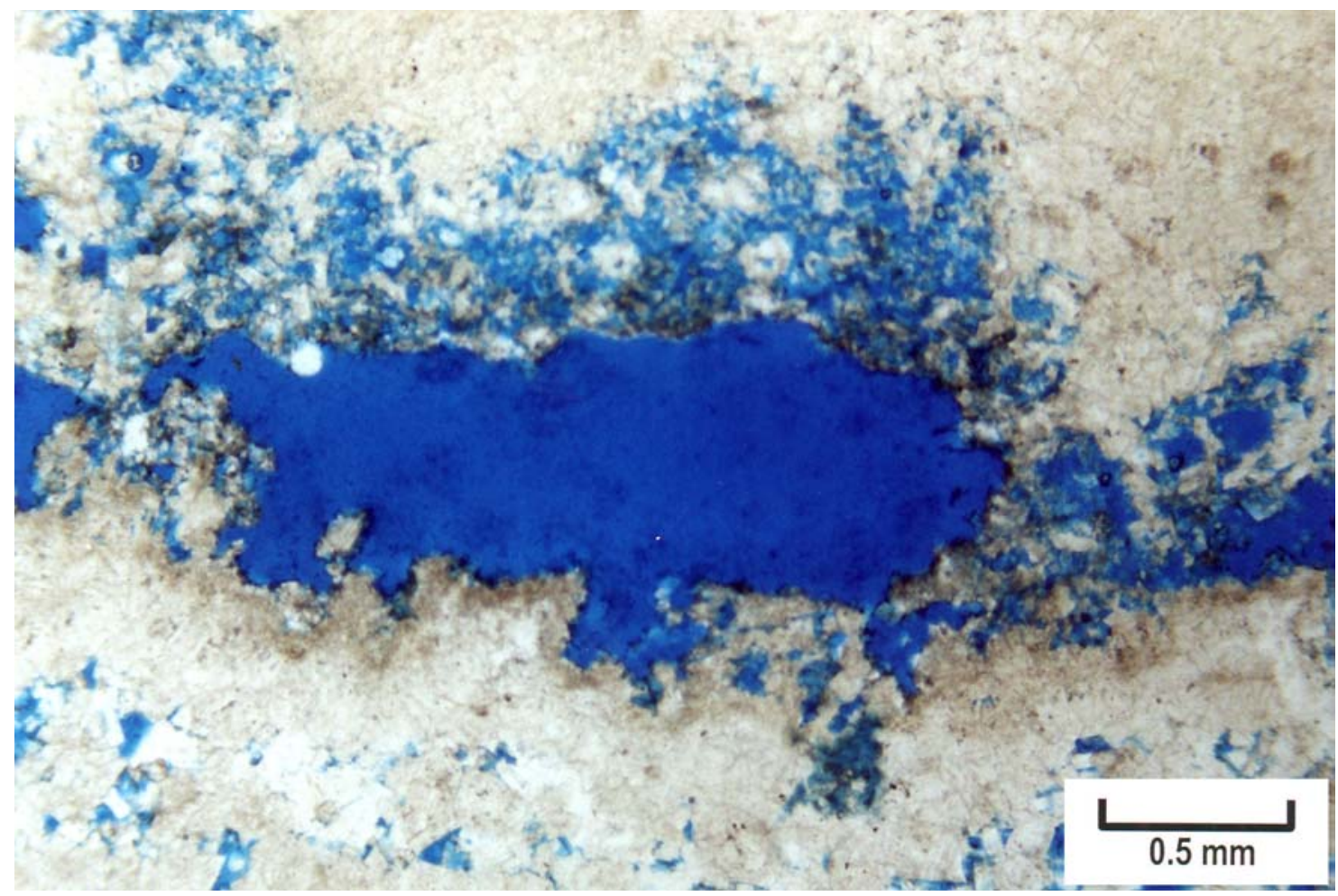




\section{BUG 7A, BUG FIELD}




\section{$\underline{6,359.3 \mathrm{ft}}$.}
Plug:
$\varnothing-4.3 \%, \mathrm{~K}-<0.01 \mathrm{md}$
Description:
dolomite; mudstone to siltstone; micas (muscovite), quartz, kerogenous organic matter; burrows.
Diagenetic events: early dolomitization (mixing zone or seepage reflux)
Pore Types: BP (ineffective)

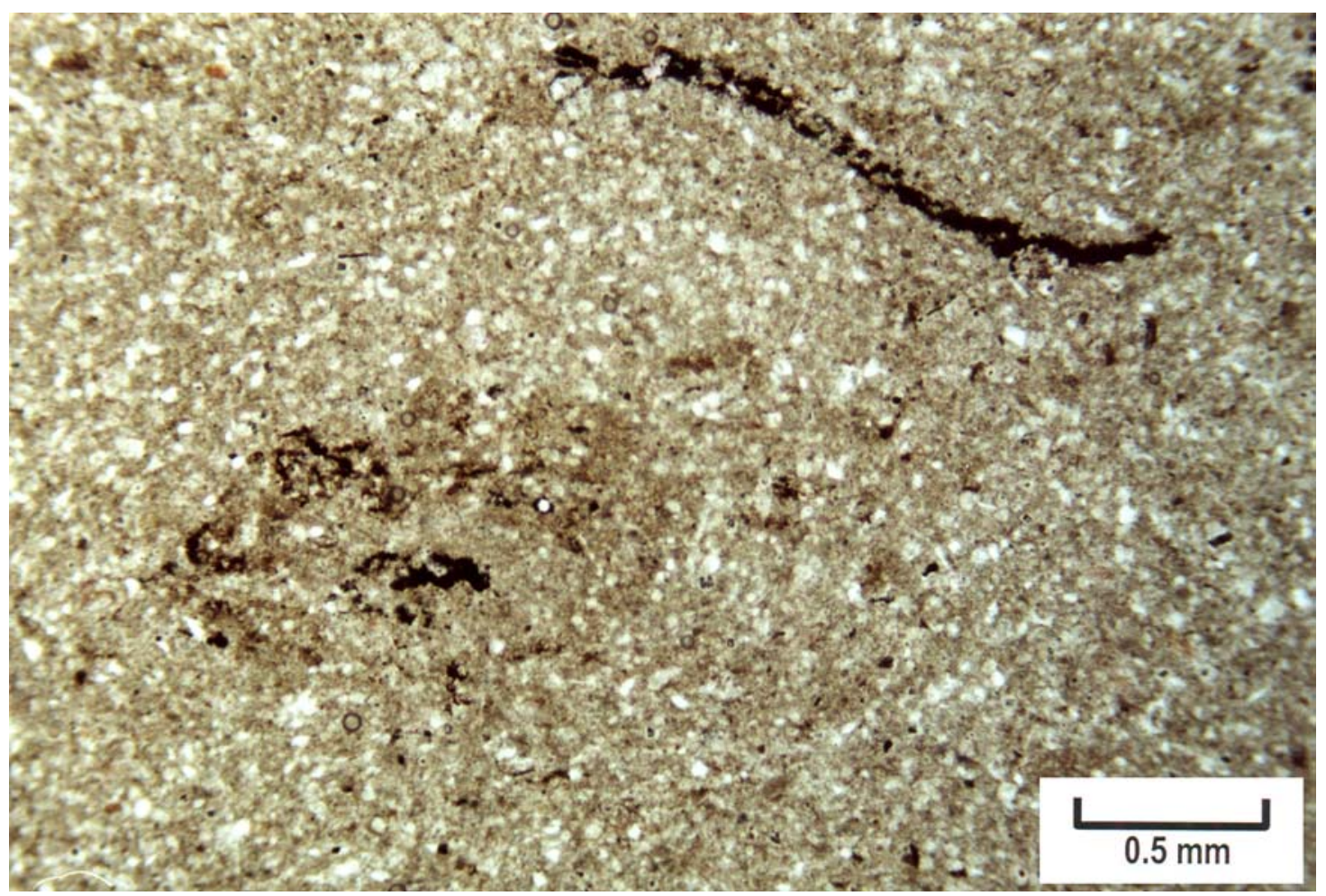




\section{$\underline{6,360.7} \mathrm{ft}$.}
Plug:
$\varnothing-5.8 \%, \mathrm{~K}-0.02 \mathrm{md}$
Description:
fossiliferous dolomite; wackestone; silty; bivalves,/brachiopods; burrows; leaching; stylolitic; some anhydrite replacement; open marine - low energy.
Diagenetic events: 1) early dolomitization (mixing zone or seepage reflux), 2) leaching, 3) stylolite formation, and 4) anhydrite replacement.
Pore Types: $\quad$ Mo (ineffective)

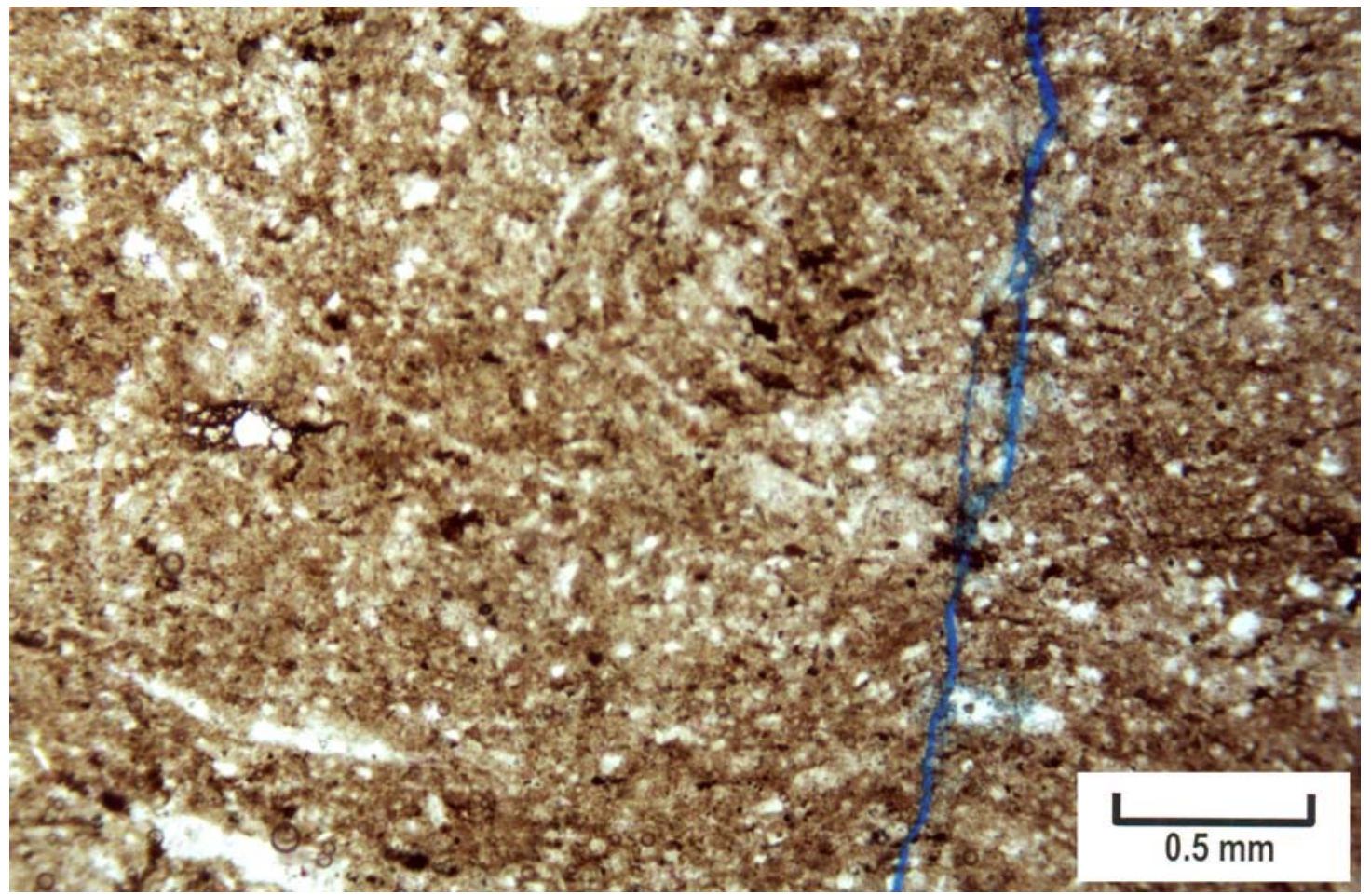




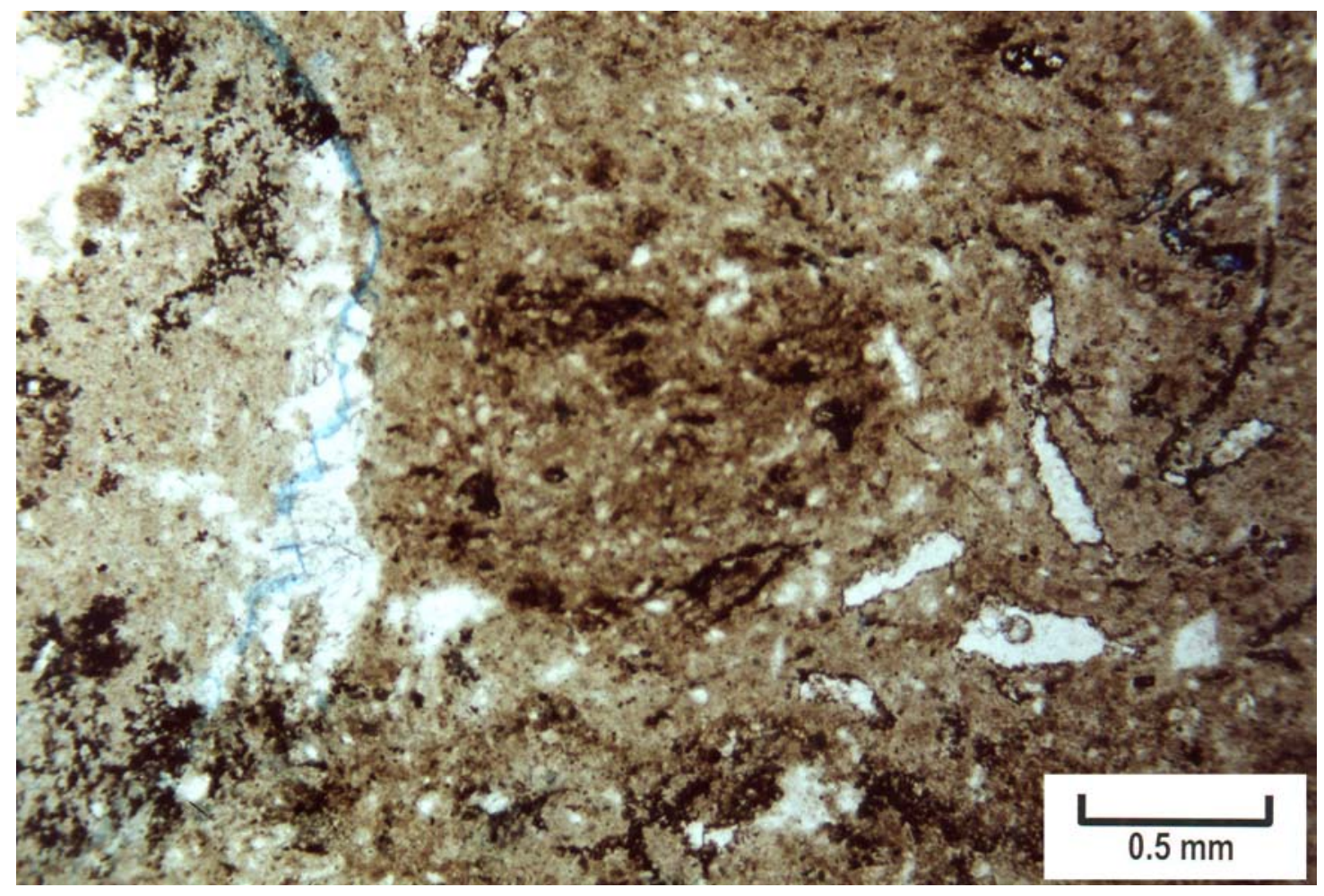




\section{BUG 10, BUG FIELD}




\section{$\underline{6,323.8 \mathrm{ft}}$.}

Plug:

Description:

Diagenetic events:

Pore Types: $\varnothing-7.7 \%, \mathrm{~K}-62 \mathrm{md}$

dolomite; phylloid-algal bafflestone, internal sediments grading into early marine cement; leaching and freshwater cementation (dogtooth and bladed) (some molds ineffective due to partial filling be cement); solution enlarged microfractures; , dogtooth spar on solution-enlarged fractures; anhydrite and bitumen.

1) early marine cementation (botryoidal cement), 2) meteoric leaching of phylloid plates, 3) freshwater cementation, 4) early dolomitization (mixing zone or seepage reflux), 5) minor anhydrite replacement, and 6) bitumen.

Mo, vug, BC, FR

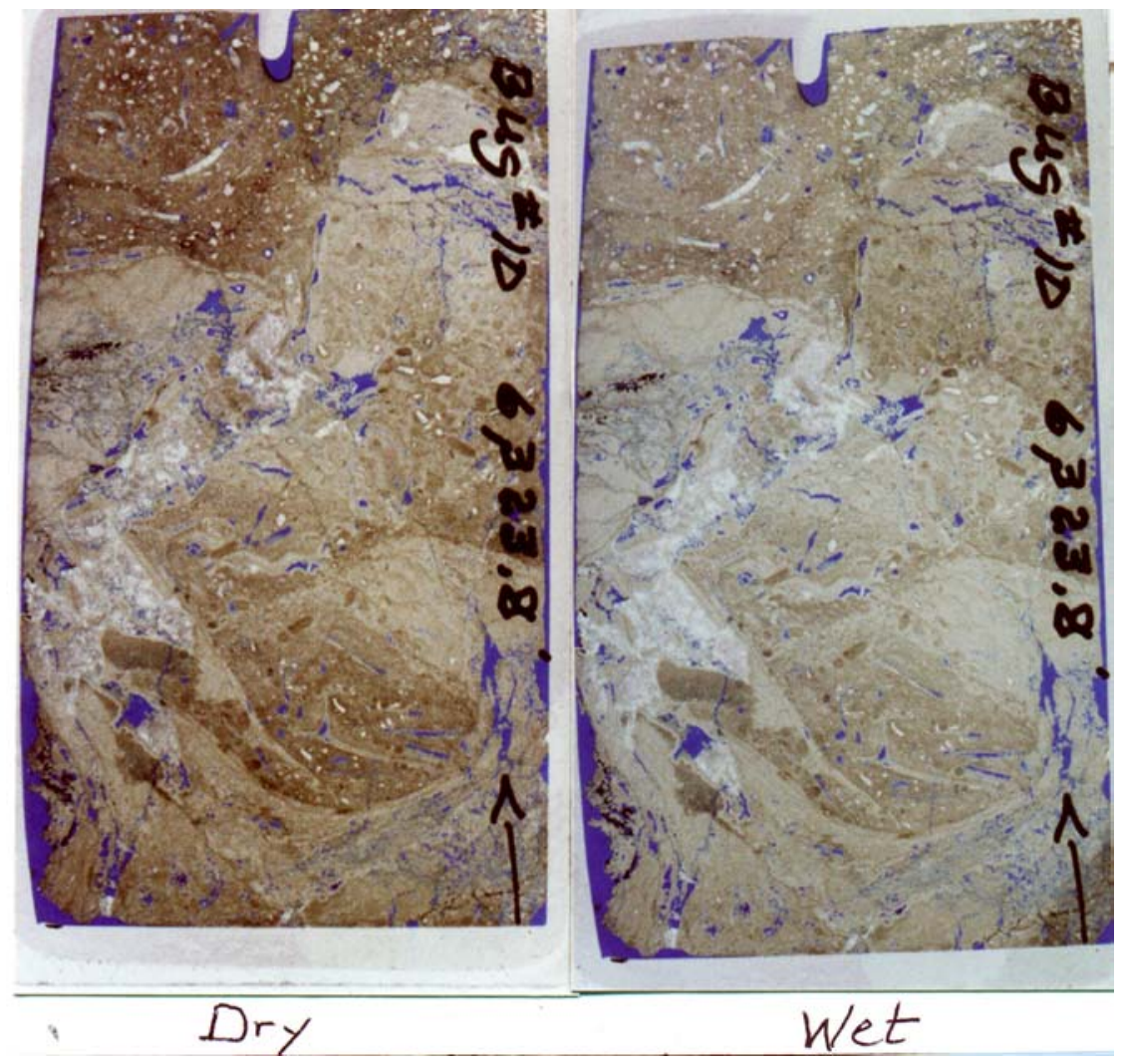




\section{$\underline{6,327.5}$ and $6,327.9 \mathrm{ft}$.}

Plug:

Description:

Pore Types: $\varnothing-10.5 \%, \mathrm{~K}-7.5 \mathrm{md}$

dolomite; phylloid-algal bafflestone; geopedals; stylolites; dolomitization; alternating environment between meteoric and marine resulting in heterogeneity with tight dolomite and dissolution features; marine $=$ early marine botryoidal cement (aragonite) (now corroded), meteoric $=$ dissolution front with dissolution microfractures, microcave environment, solution pits, patchy micro-box-work dolomite; late anhydrite.

Diagenetic events: 1) early marine cementation (botryoidal cement), 2) meteoric leaching of phylloid plates and dissolution, 3) freshwater cementation, 4) early dolomitization (mixing zone or seepage reflux), 5) meteoric bladed dolomite, and 6) anhydrite replacement. mainly BC, vugs, some BP, FR

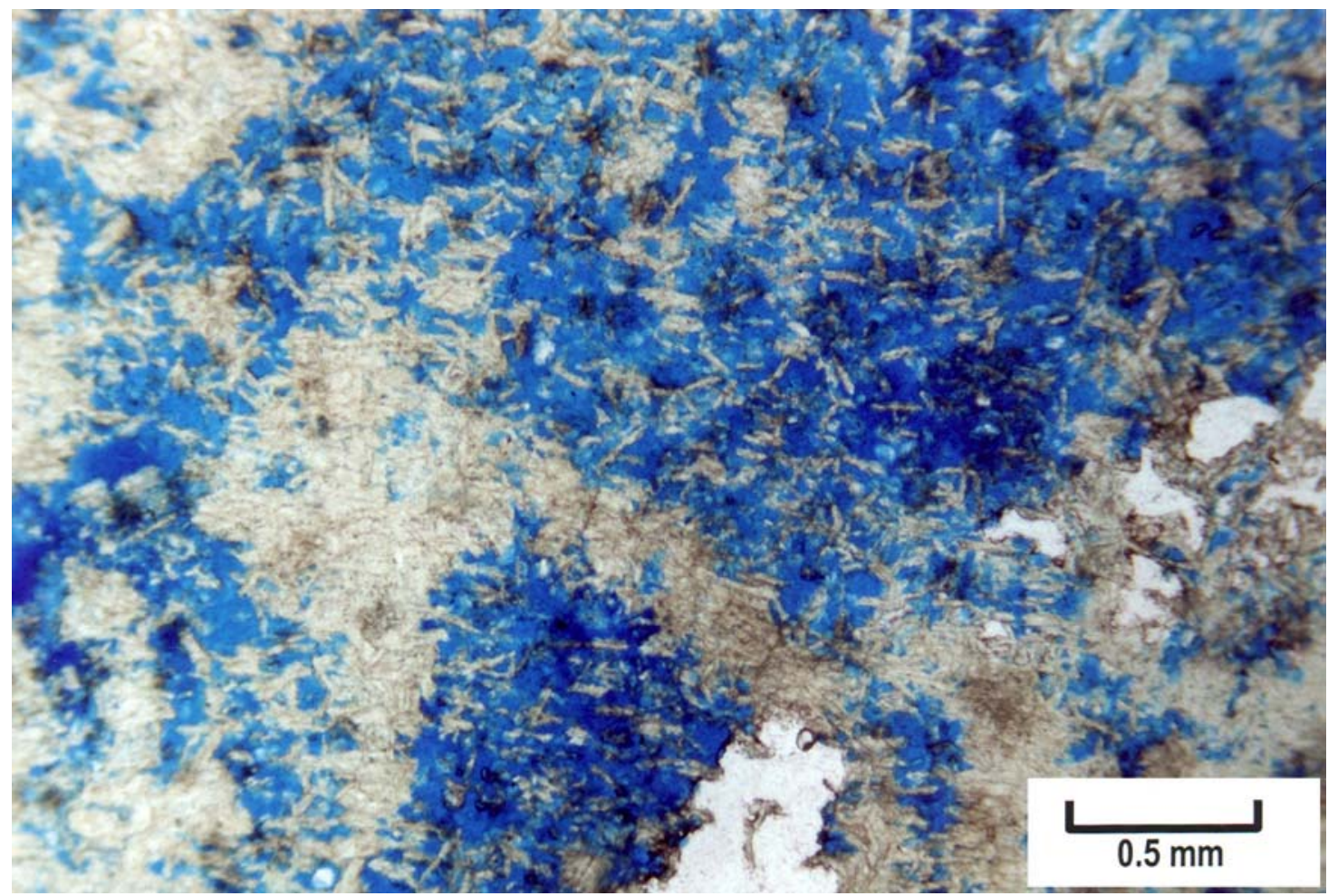



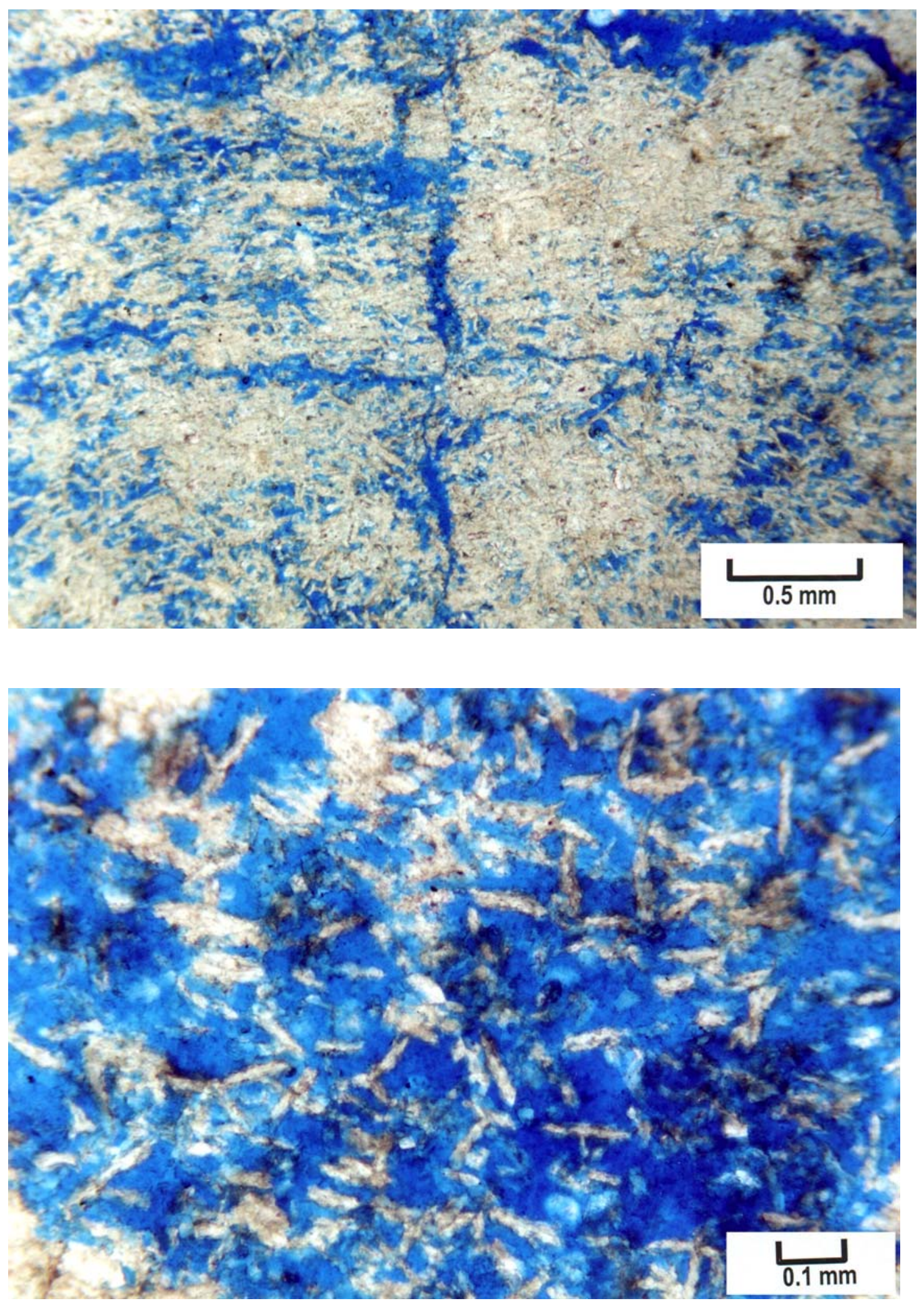

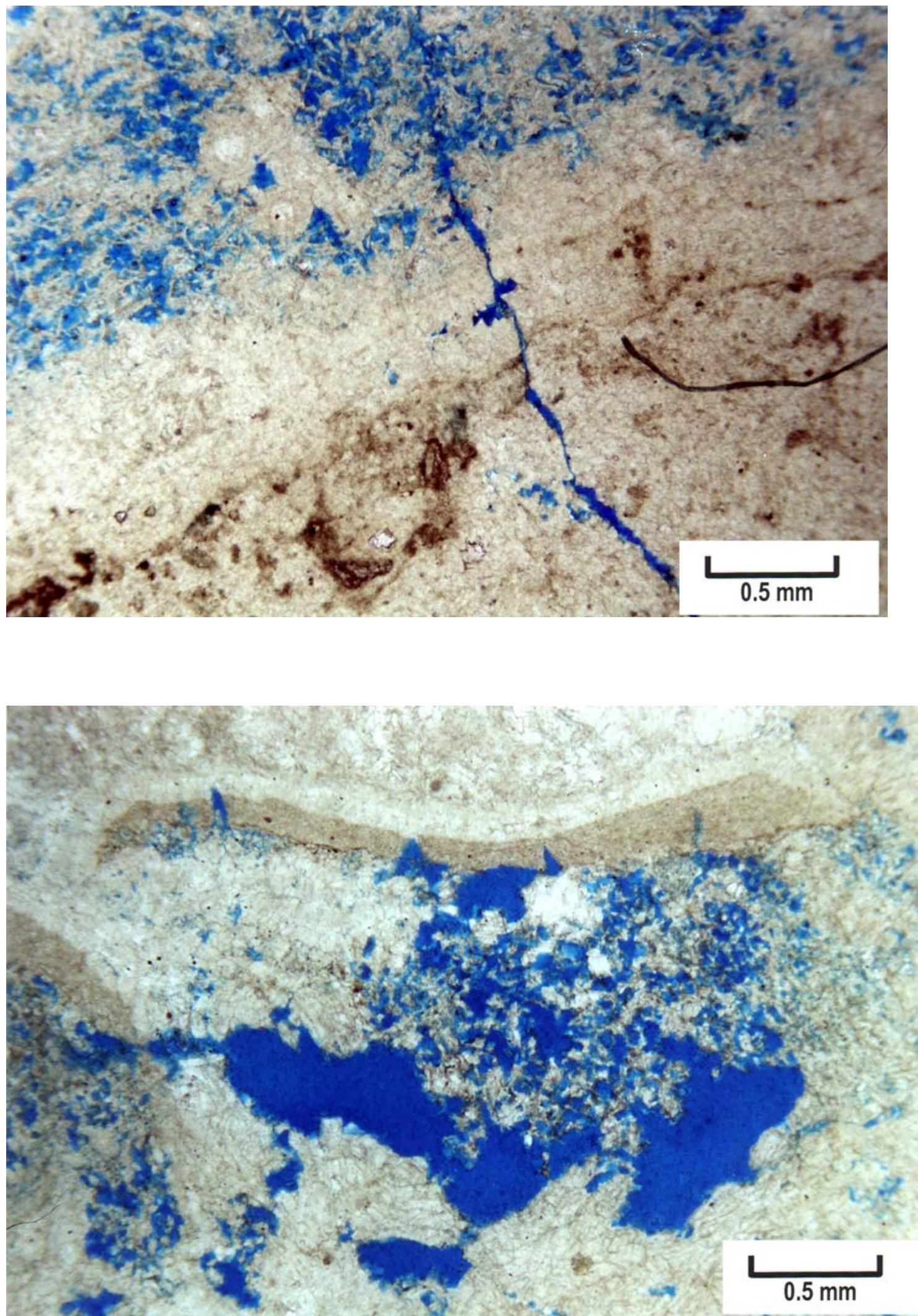

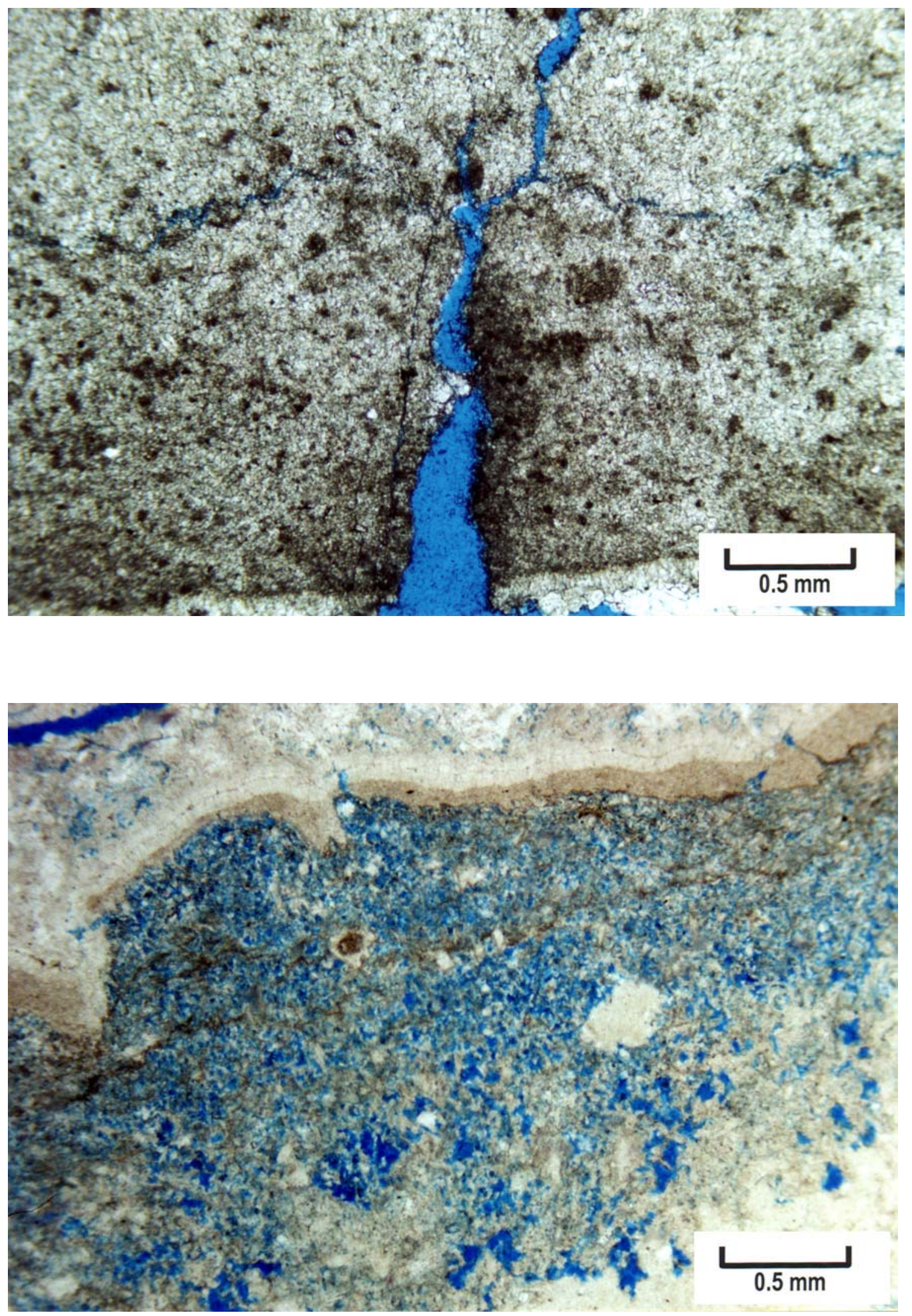


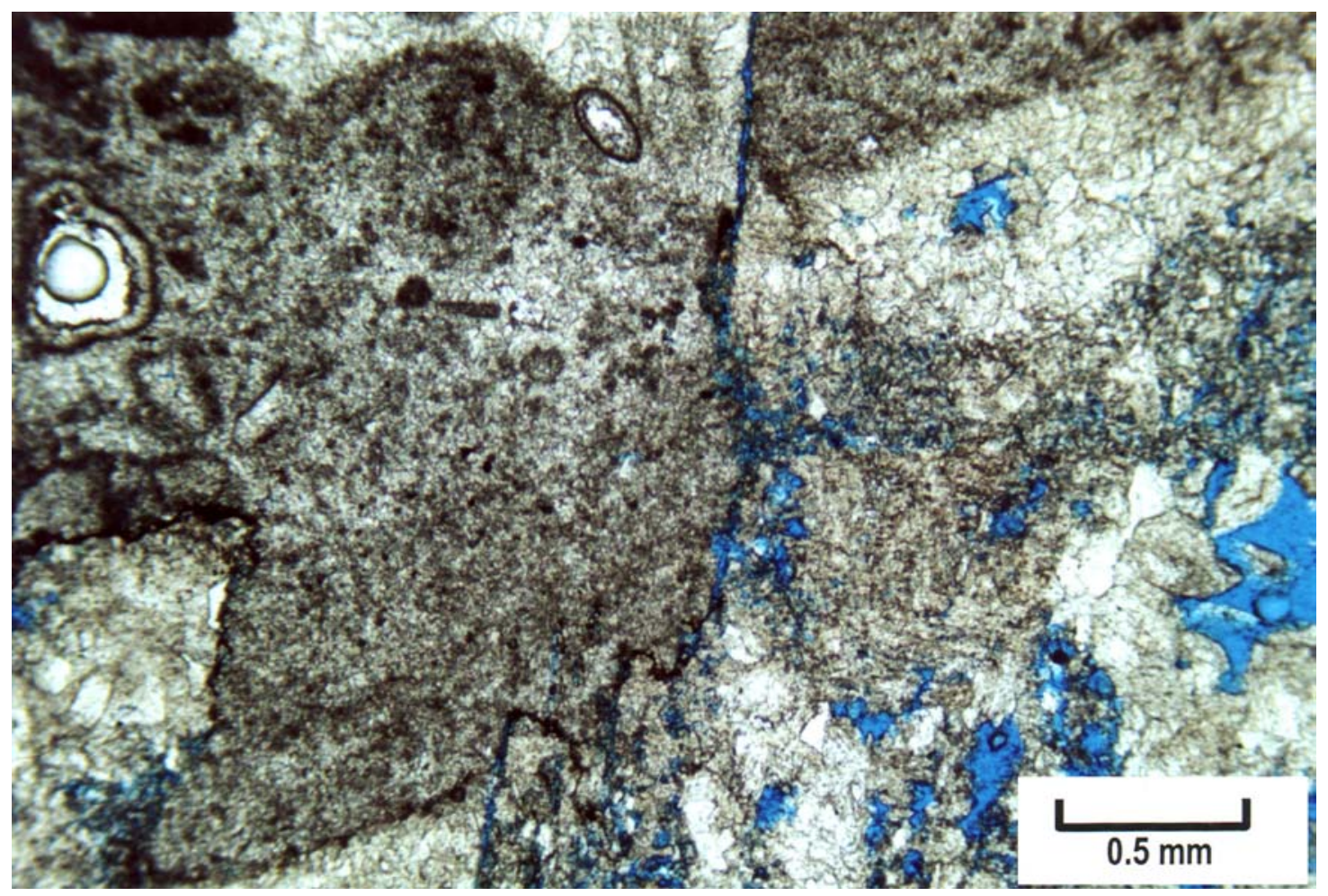




\section{BUG 13, BUG FIELD}




\section{$\underline{5,930.6 \text { ft. }}$}

Plug:

Description:

Pore Types: $\varnothing-9.3 \%, \mathrm{~K}-15 \mathrm{md}$

dolomite; pisolitic/peloidal grainstone; soil pisolites indicating subaerial exposure of the mound cap; solution-enlarged channels; late microporosity (reservoir near faults (?); anhydrite and bitumen.

Diagenetic events: 1) meteoric leaching of peloids and pisolites, 2) early dolomitization (mixing zone or seepage reflux), 3) microporosity to channel porosity development, 4) minor anhydrite replacement, and 5) bitumen.

Mo, BC, micro-BC, $\mathrm{CH}$, FR

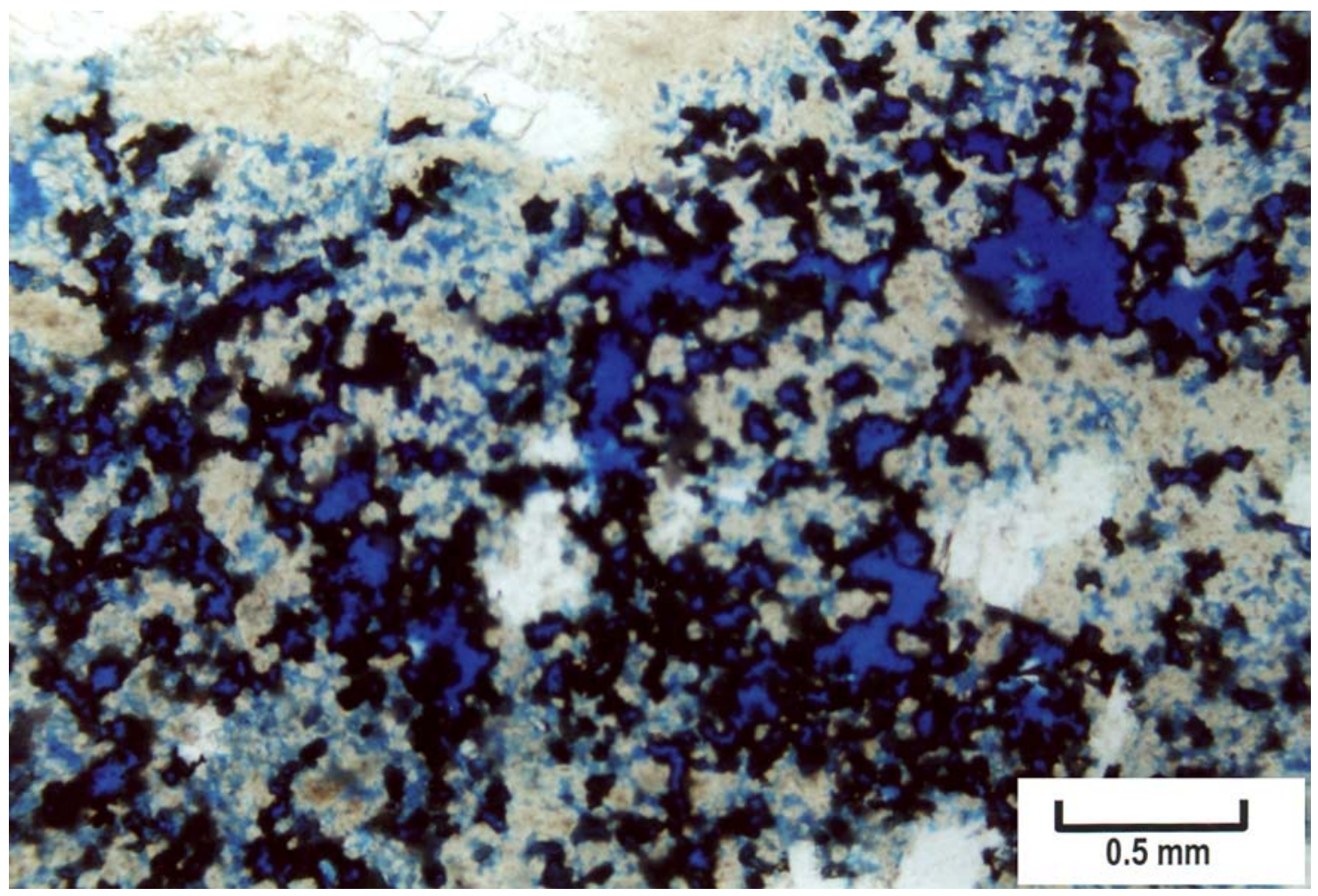




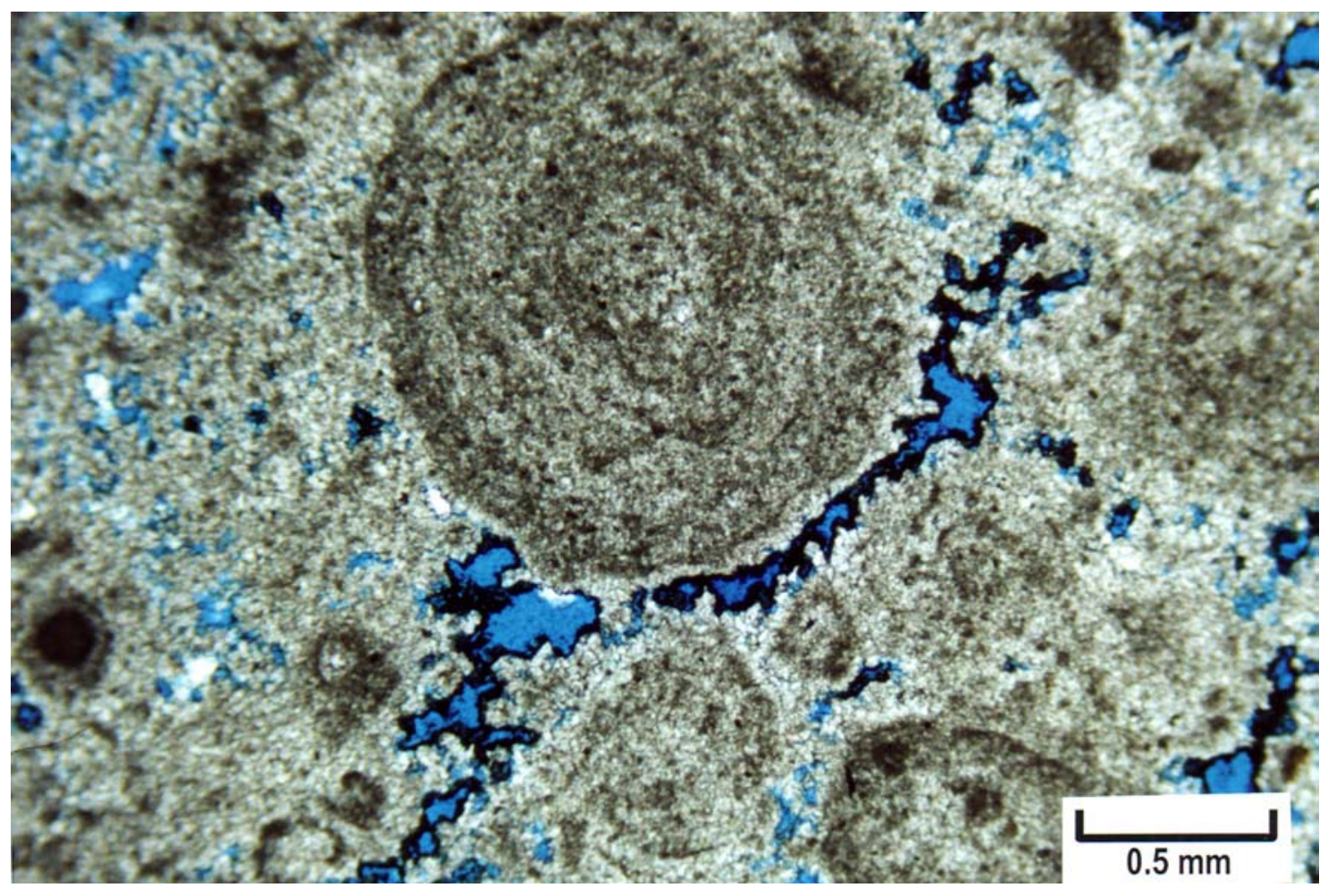




\section{$\underline{5,935.8} \mathbf{f t}$.}

Plug:

Description:

Diagenetic events:

Pore Types: $\varnothing-11.9 \%, \mathrm{~K}-14 \mathrm{md}$

dolomite; tight phylloid-algal bafflestone; upper mound; alternating environment between marine (early botryoidal cement [attached by dissolution first] with dust lines) and meteoric (bladed dolomitic cement [etching]); dissolution features include microbox-work dolomite to vugs to solution-enlarged fractures; late anhydrite; minor silica.

1) early marine cementation (botryoidal cement), 2) meteoric leaching of phylloid plates and dissolution, 3) freshwater cementation, 4) early dolomitization (mixing zone or seepage reflux), 5) meteoric bladed dolomite, 6) anhydrite replacement, and 7) silicification.

$\mathrm{SH}, \mathrm{BP}, \mathrm{Mo}, \mathrm{BC}$, FR, vugs

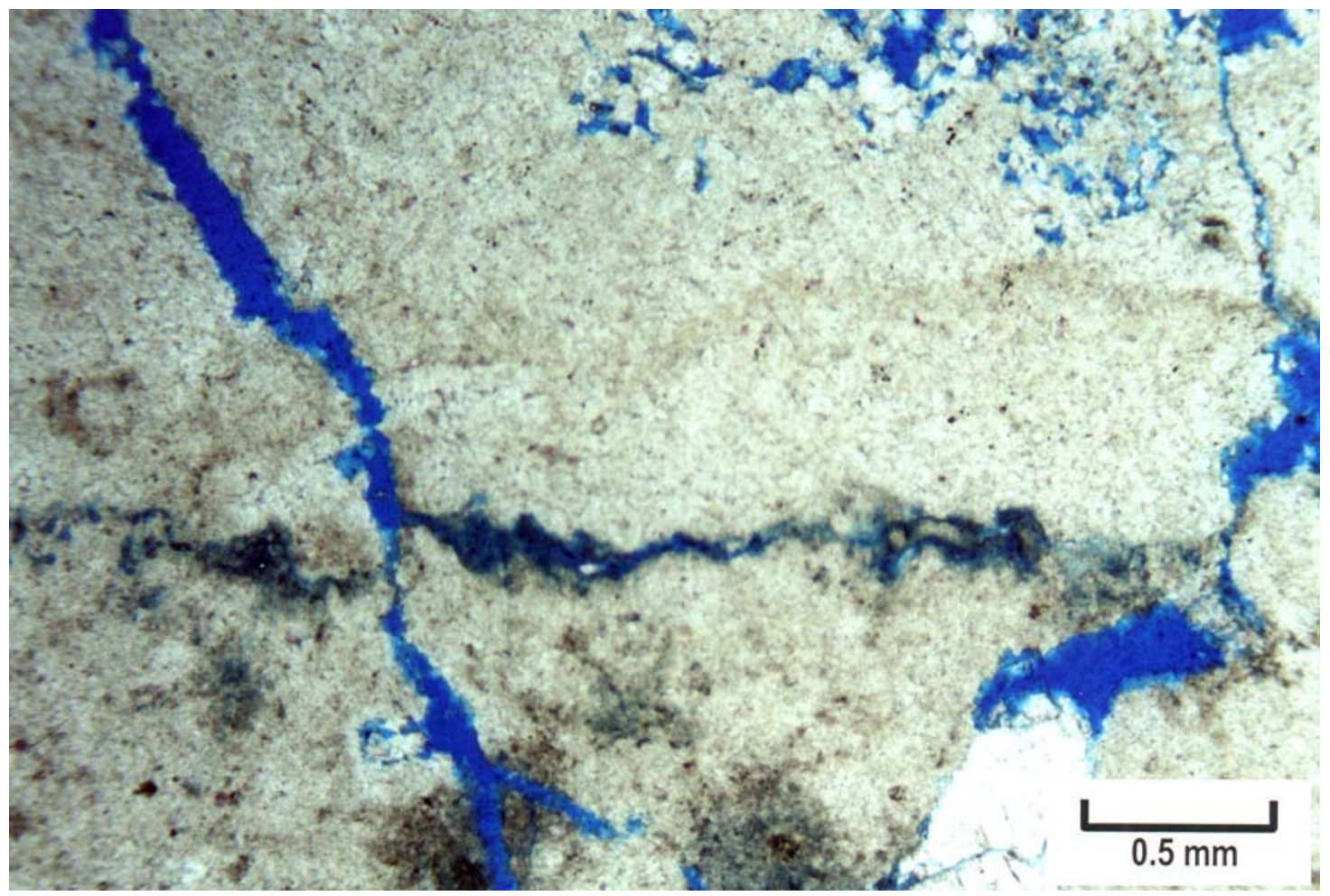




\section{$\underline{5,939.6} \mathbf{f t}$.}

Plug:

Description:

Diagenetic events:

Pore Types: $\varnothing-12 \%, \mathrm{~K}-6.9 \mathrm{md}$

dolomite; phylloid-algal bafflestone; lower mound; early marine botryoidal cement with a dust line and meteoric cement (attached); dissolution features include micro-box-work dolomite; intercrystalline to unaltered.

1) early marine cementation (botryoidal cement), 2) meteoric leaching of phylloid plates and dissolution, 3) freshwater cementation, 4) early dolomitization (mixing zone or seepage reflux).

$\mathrm{BC}$

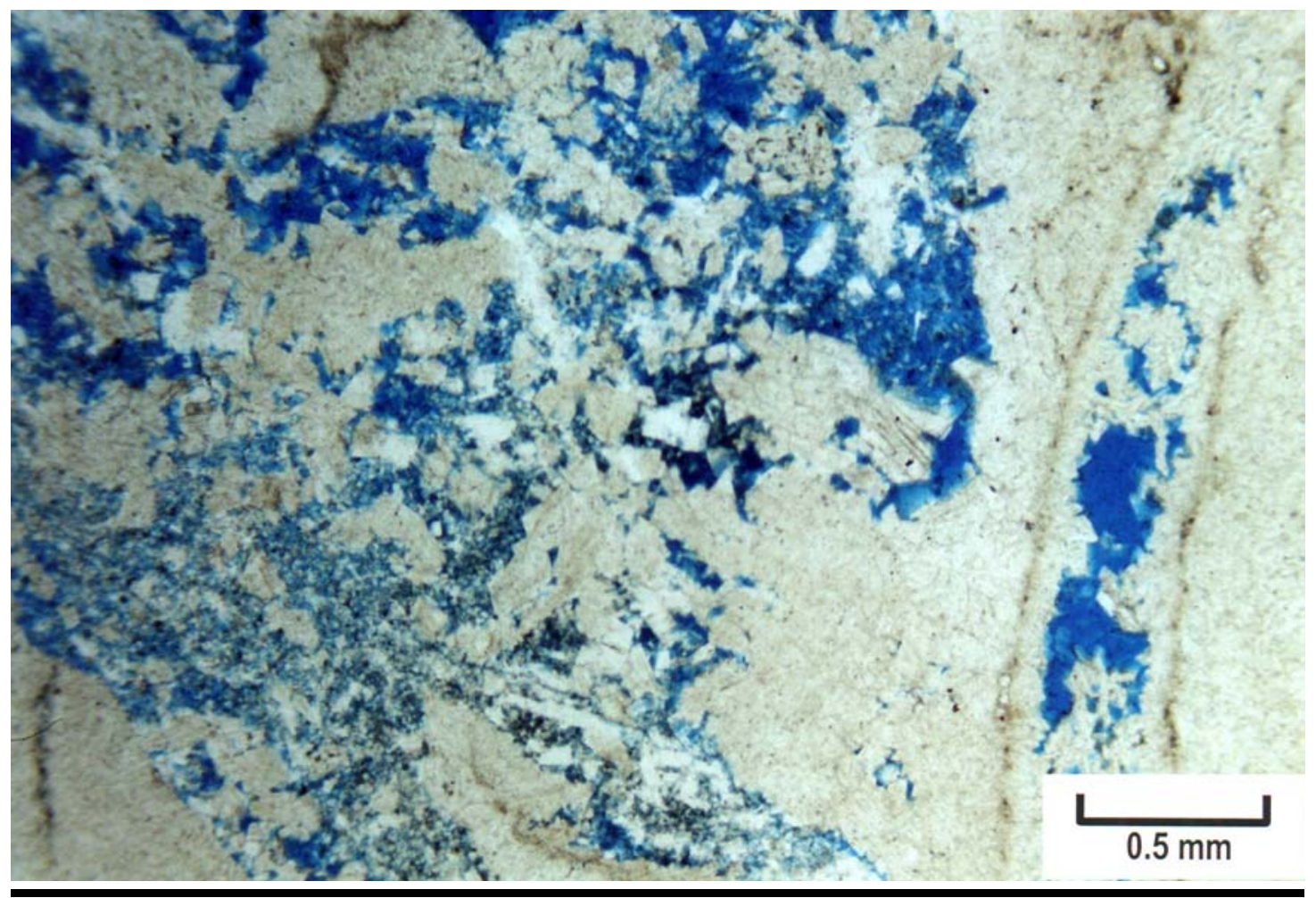




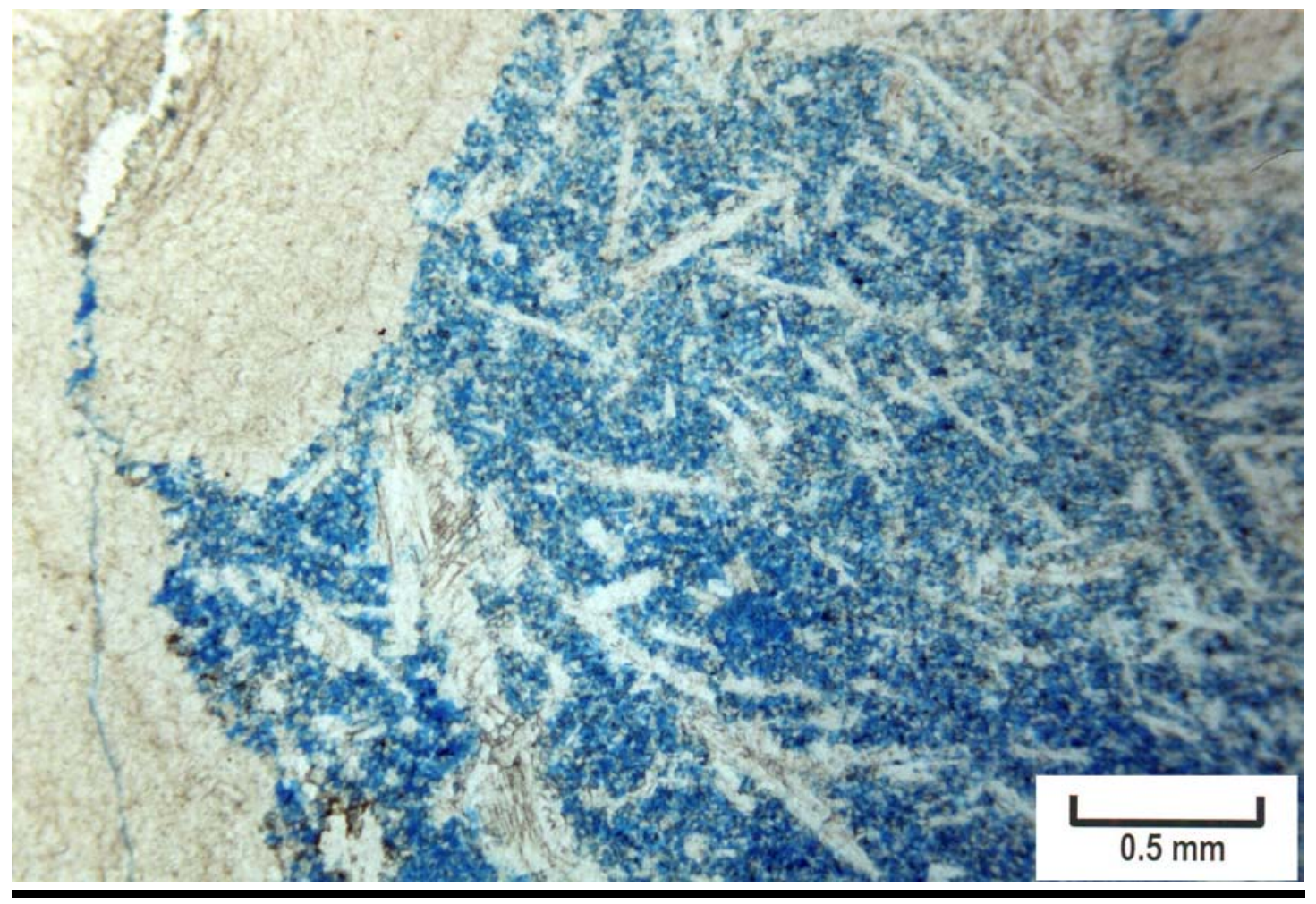




\section{$\underline{5,941.6} \mathbf{f t}$.}

Plug:

Description:

Diagenetic events:

Pore Types: $\varnothing-8.5 \%, \mathrm{~K}-1.8 \mathrm{md}$

dolomite; phylloid-algal bafflestone; early marine botryoidal and microbial cement nearly completely dissolved; meteoric (bladed dolomitic cement); dissolution front and dissolution features including solution-enlarged microfractures, molds, and cooccurring micro-box-work/hollow dolomite; little anhydrite or bitumen.

1) early marine cementation (botryoidal cement), 2) meteoric leaching of phylloid plates and dissolution, 3) freshwater cementation, 4) early dolomitization (mixing zone or seepage reflux), 5) meteoric bladed dolomite, 6) some anhydrite replacement, and 7) some bitumen.

Mo, BC, BP, FR

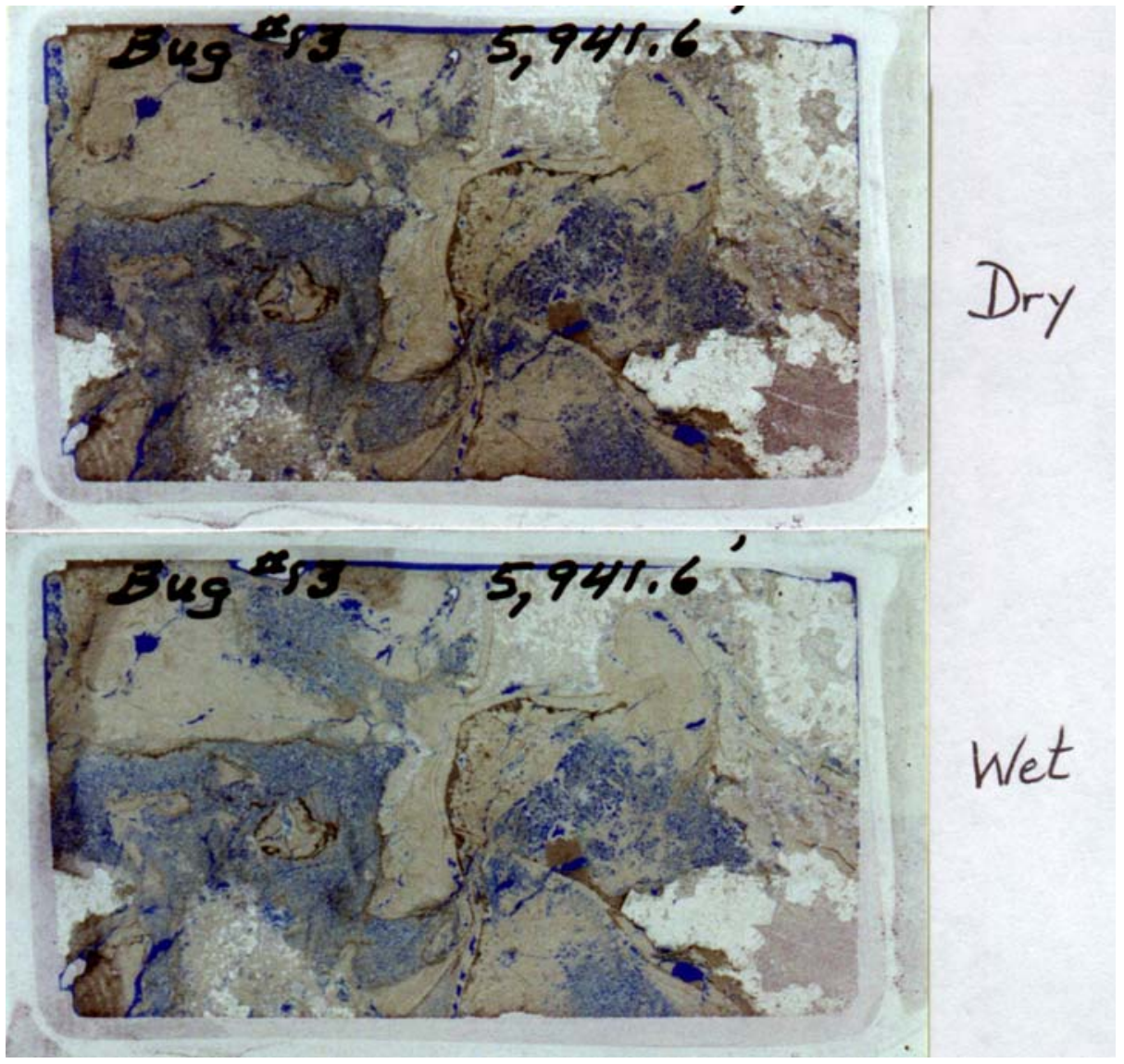




\section{BUG 16, BUG FIELD}




\section{$\underline{6,299.3 \mathrm{ft}}$.}

Plug:

Description:

Diagenetic events:

Pore Types: $\varnothing-10.3 \%, \mathrm{~K}-3.4 \mathrm{md}$

dolomite; phylloid-algal bafflestone; early marine cements with dust lines and meteoric cements; dissolution fabric with microbox-work dolomite, vugs (lined with bitumen), solution-enlarged fractures and lots of microfractures, ghosts of cement and patchy areas of dissolution; modest bitumen.

1) early marine cementation (botryoidal cement), 2) meteoric leaching of phylloid plates and dissolution, 3) freshwater cementation, 4) early dolomitization (mixing zone or seepage reflux), and 5) bitumen.

Mo, vug, FR, BC

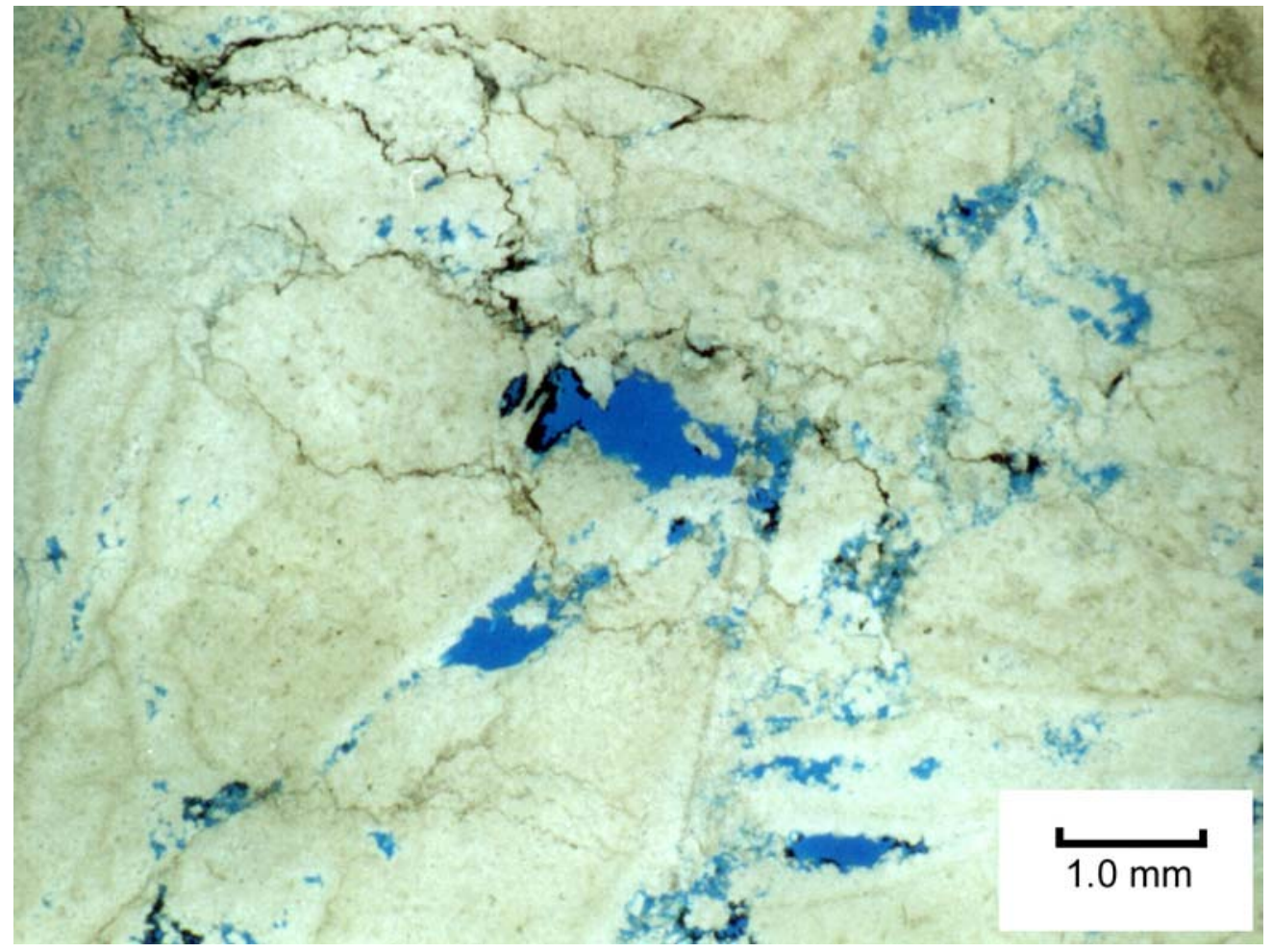



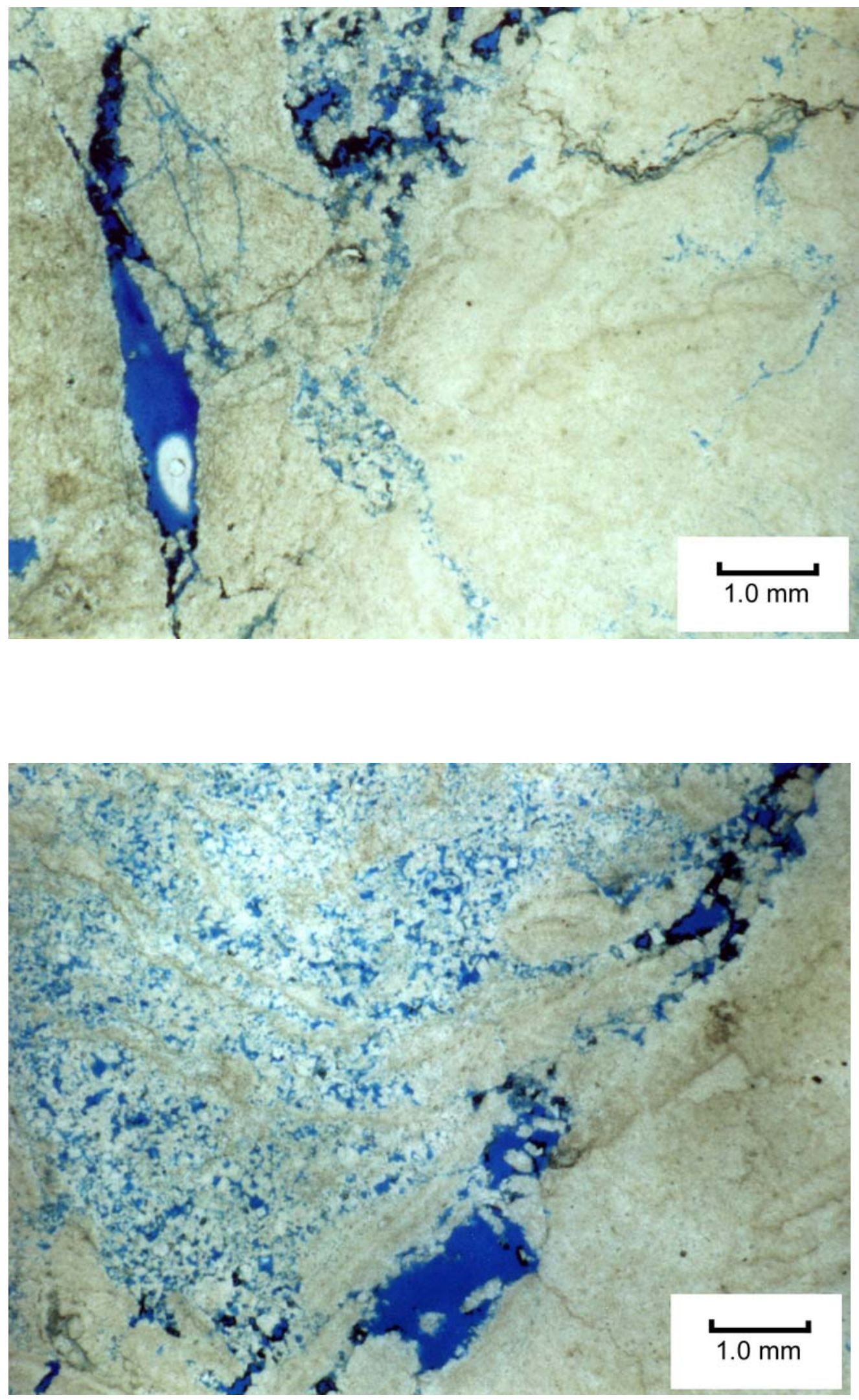

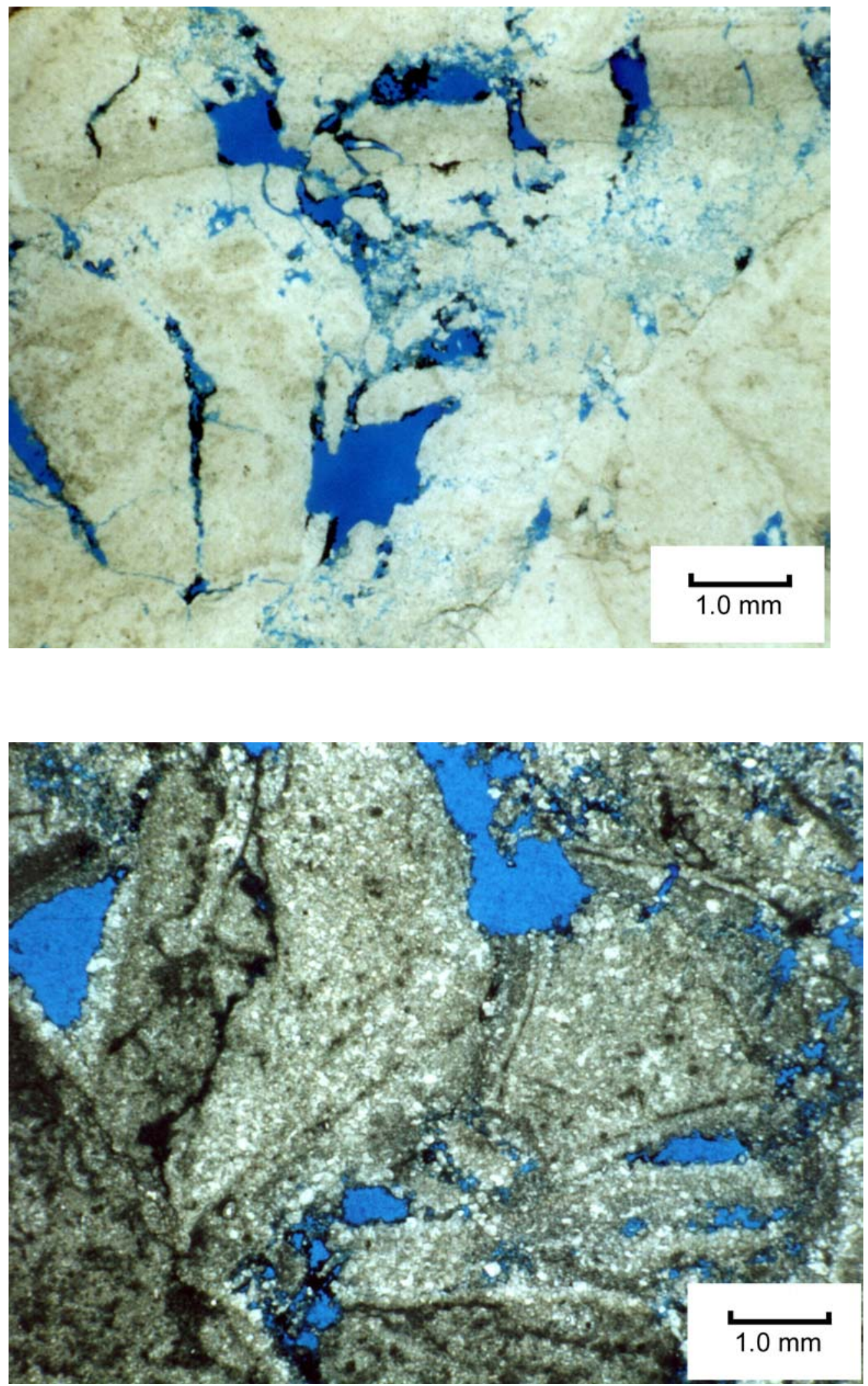

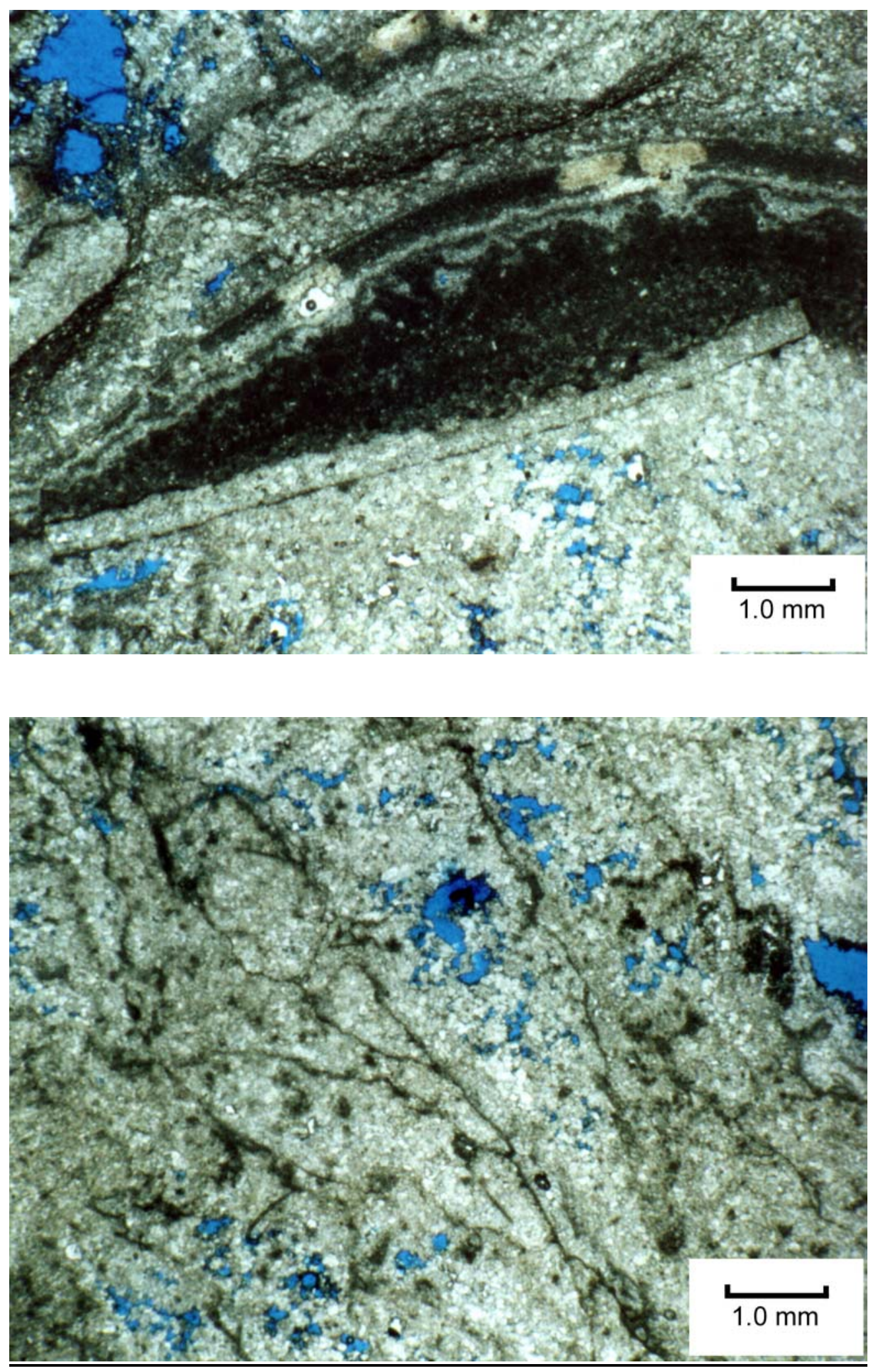


\section{$\underline{6,300.5} \mathrm{ft}$.}

Plug:

Description:

Diagenetic events:

Pore Types: $\varnothing-15.9 \%, \mathrm{~K}-76 \mathrm{md}$

dolomite; tight phylloid-algal bafflestone; upper mound; alternating environment between marine (early botryoidal) and meteoric (dogtooth cement); massive dissolution with dissolution front and dissolution features including micro-box-work/hollow dolomite, vugs (lined with bitumen); late microporosity (without bitumen).

1) early marine cementation (botryoidal cement), 2) meteoric leaching of phylloid plates and dissolution, 3) freshwater cementation, 4) early dolomitization (mixing zone or seepage reflux), 5) microporosity development, and 6) bitumen. vug, BC, SH, FR, micro-BC

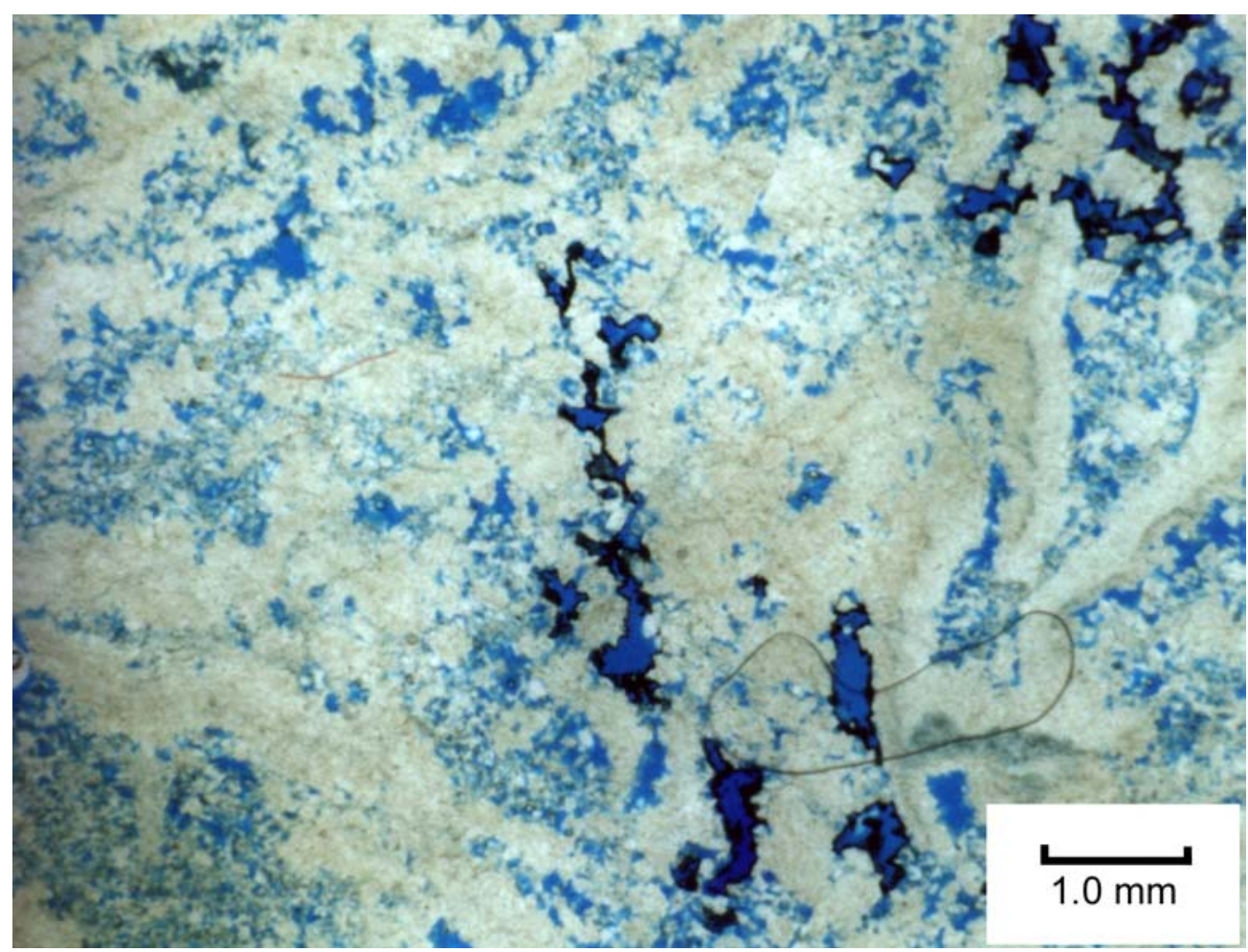



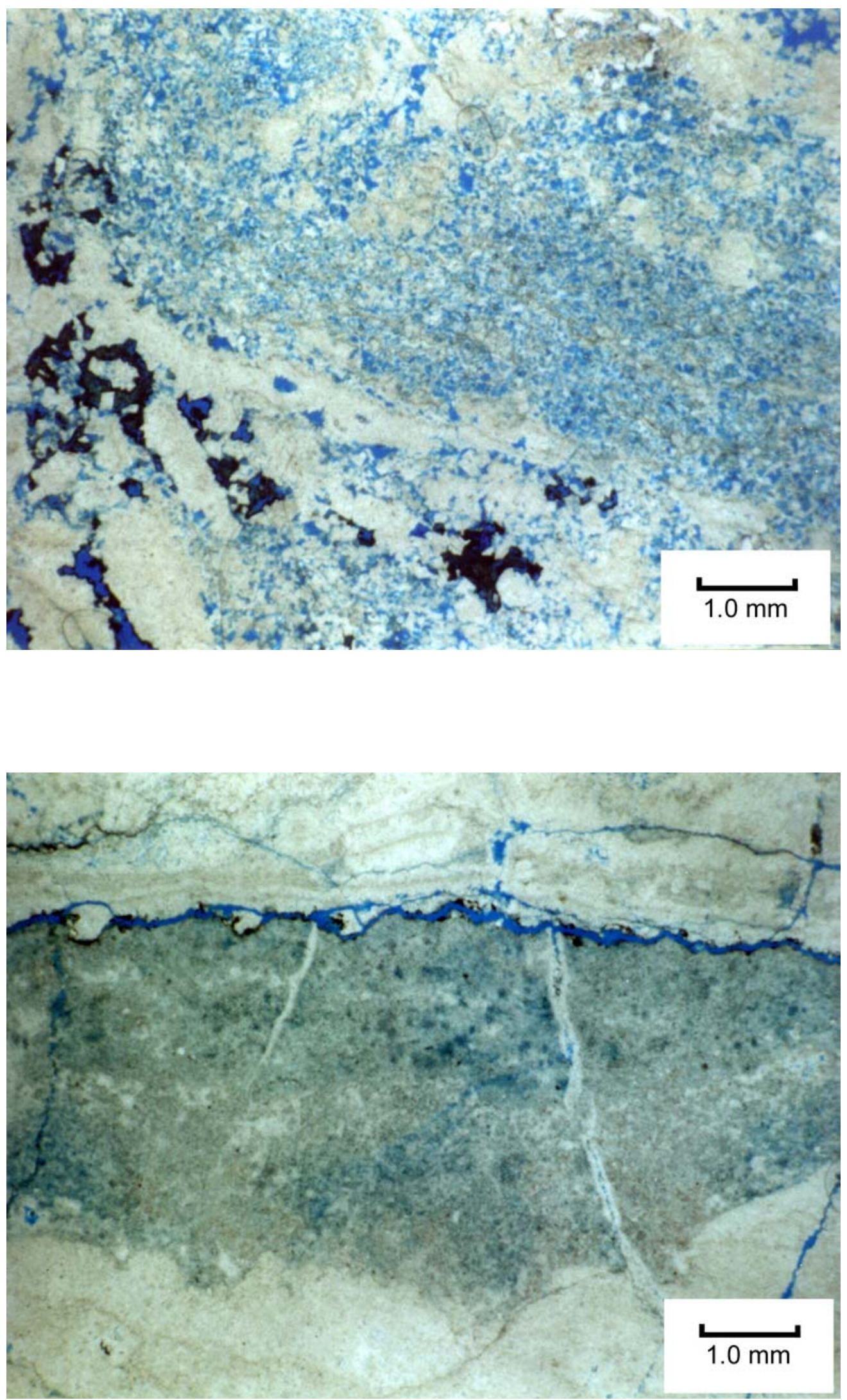

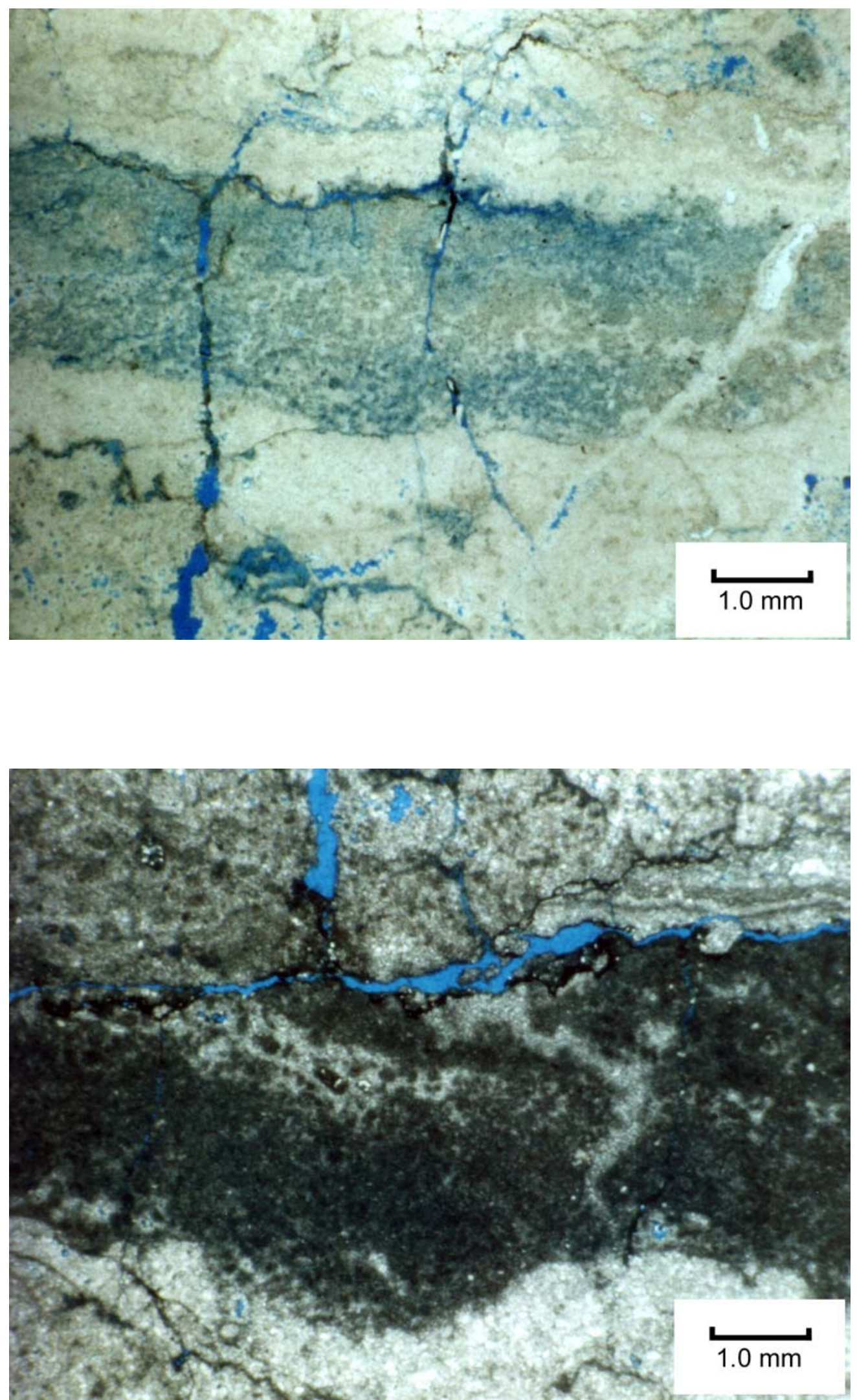


\section{$\underline{6,314.3 \mathrm{ft}}$.}

Plug:

Description:

Diagenetic events:

Pore Types: $\varnothing-13.8 \%, \mathrm{~K}-14 \mathrm{md}$

dolomite; phylloid-algal bafflestone; original shelter pores and geopedals; freshwater bladed cements; dissolution front and dissolution features including large solution-enlarged open fractures, micro-box-work/hollow dolomite, vugs (connected to fractures); some late microporosity (with microbial character) indicating a nearby fault or conduit; replacement anhydrite.

1) meteoric leaching of phylloid plates and dissolution, 2) freshwater cementation, 3) early dolomitization (mixing zone or seepage reflux), 4) microporosity development, and 5) anhydrite replacement

$\mathrm{SH}$, vug, $\mathrm{BC}$, FR, micro-BC

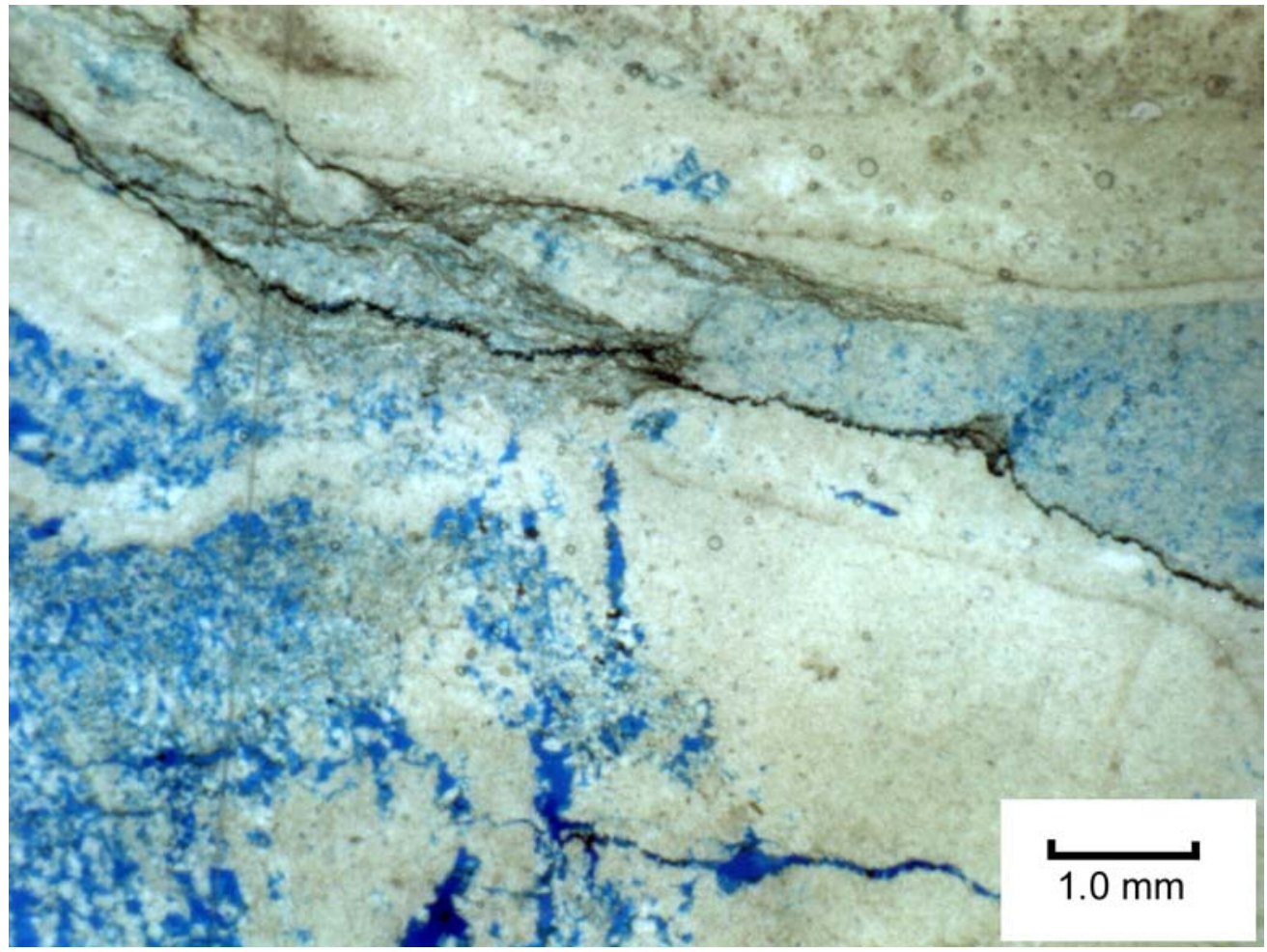



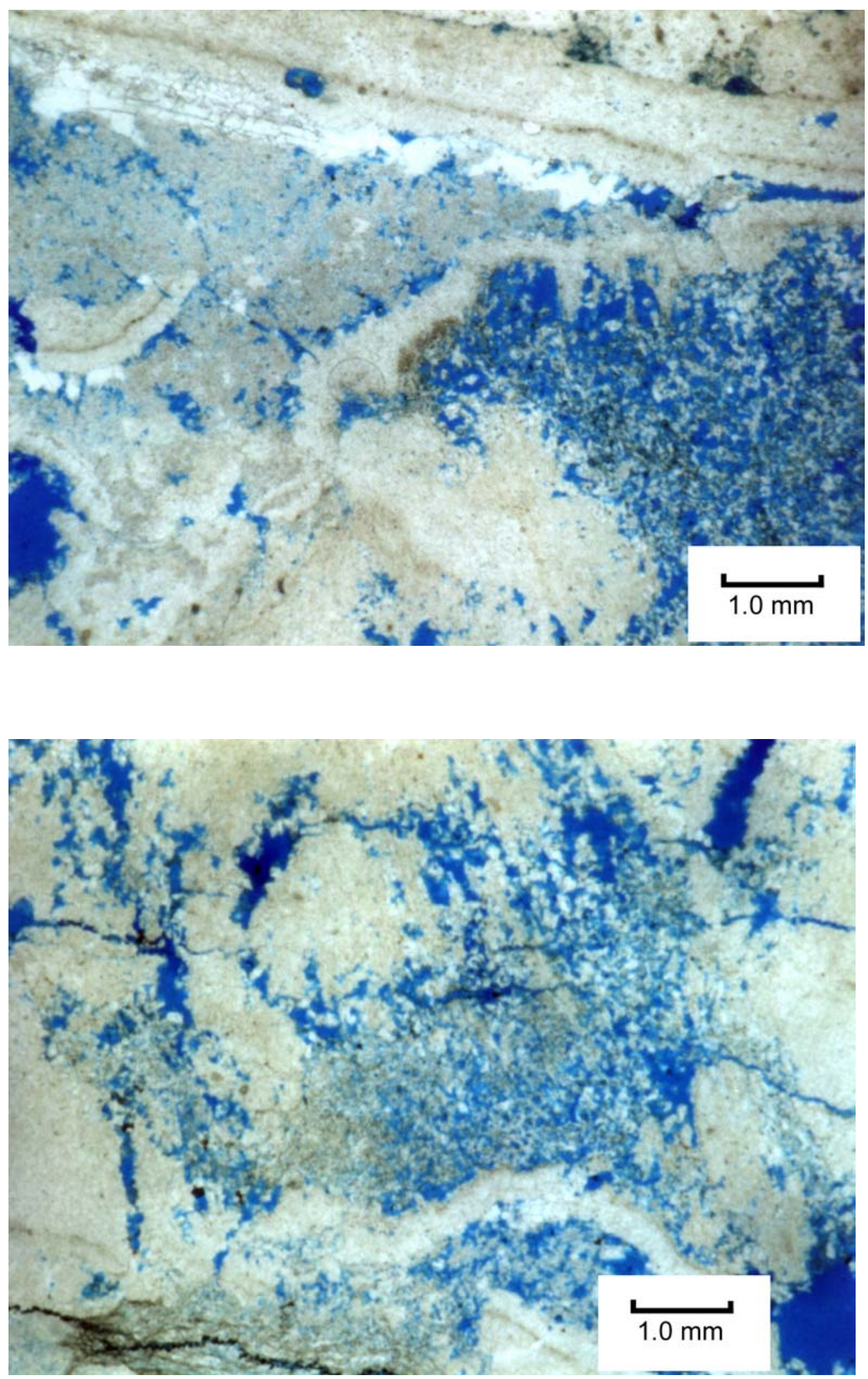

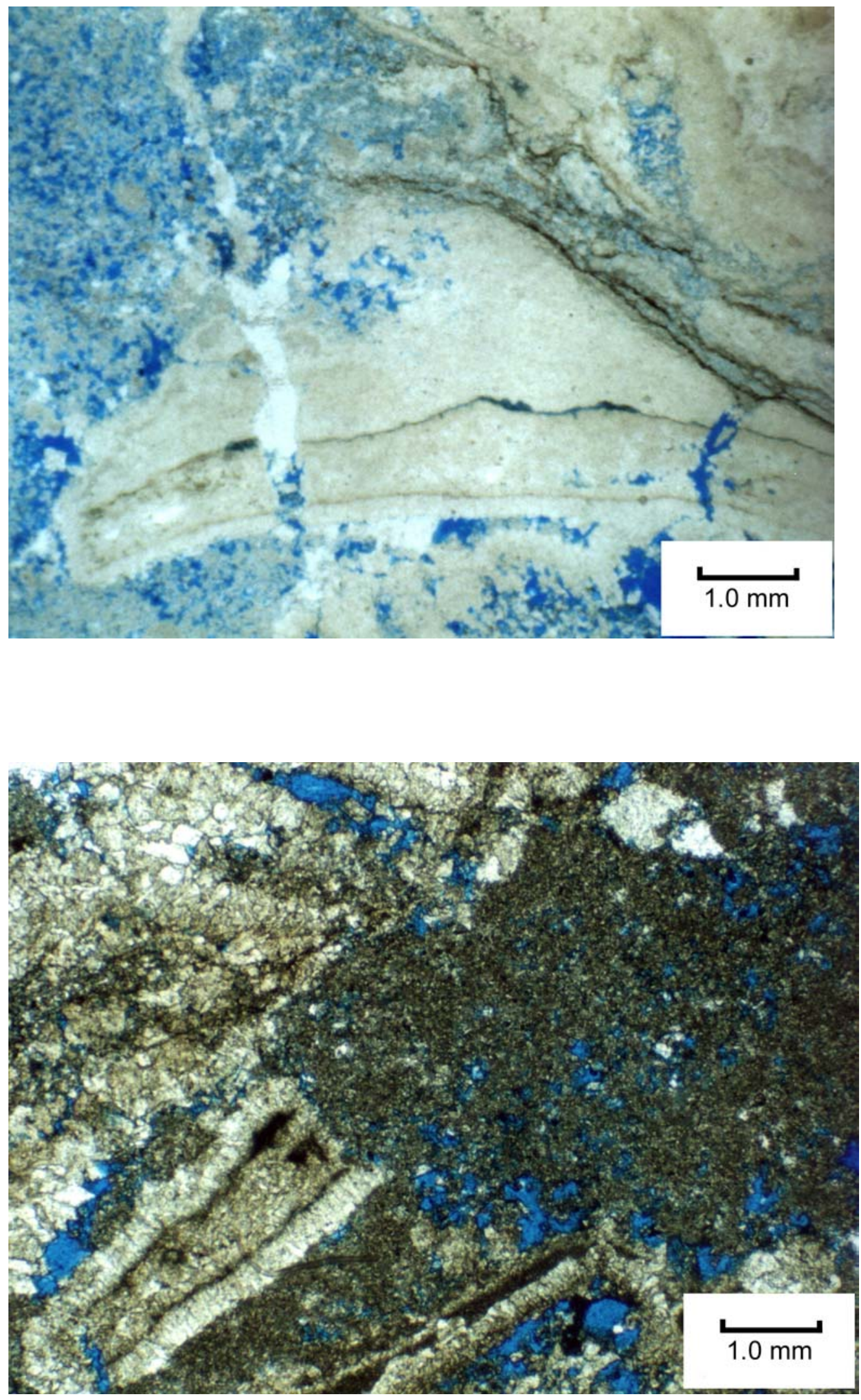


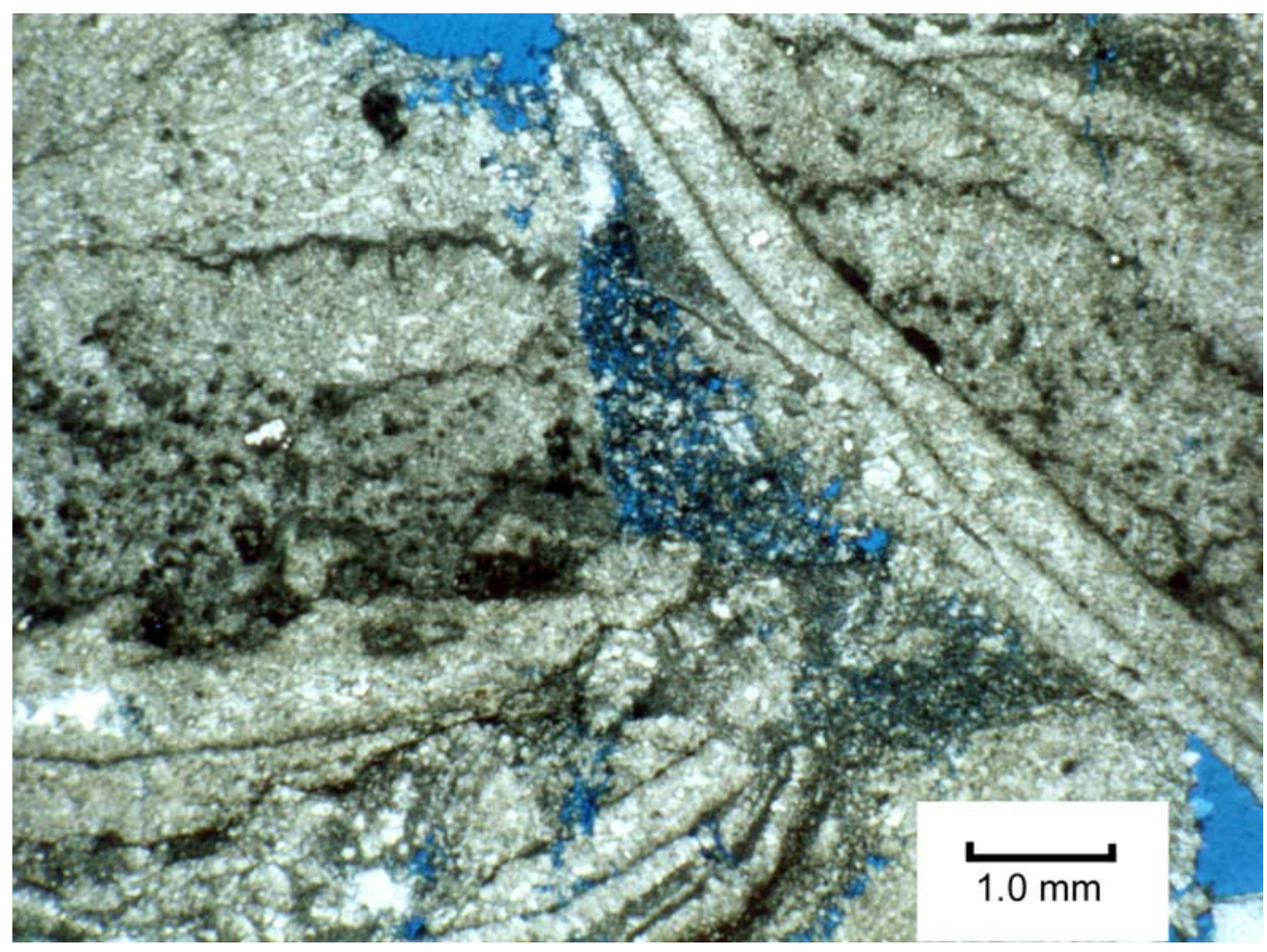

